FACULDADE DE ZOOTECNIA E ENGENHARIA DE ALIMENTOS

THAÍS CAMILO CORRÊA

Imunobiológicos para o diagnóstico laboratorial de ranavirose: clonagem e expressão do gene MCP de isolado brasileiro de Ranavirus e produção de anticorpos policlonais anti-proteína MCP recombinante 


\section{THAÍS CAMILO CORRÊA}

Imunobiológicos para o diagnóstico laboratorial de ranavirose: clonagem e expressão do gene MCP de isolado brasileiro de Ranavirus e produção de anticorpos policlonais anti-proteína MCP recombinante

Versão Corrigida

Tese apresentada à Faculdade de

Zootecnia e Engenharia de Alimentos da Universidade de São Paulo, como parte dos requisitos para a obtenção do Título de Doutor em Ciências.

Área de Concentração: Qualidade e Produtividade Animal

Orientador: Prof. Dr. Ricardo Luiz Moro de Sousa 
Ficha catalográfica elaborada pelo Serviço de Biblioteca e Informação, FZEA/USP, com os dados fornecidos pelo(a) autor(a)

Corrêa, Thaís Camilo

Imunobiológicos para o diagnóstico laboratorial de ranavirose: clonagem e expressão do gene MCP de

isolado brasileiro de Ranavirus e produção de ... /

Thaís Camilo Corrêa ; orientador Ricardo Luiz Moro

de Sousa. -- Pirassununga, 2019.

$131 \mathrm{f}$.

Tese (Doutorado - Programa de Pós-Graduação em Zootecnia) -- Faculdade de Zootecnia e Engenharia de Alimentos, Universidade de São Paulo.

1. Virologia. 2. ELISA-IB. 3. Proteína

recombinante. 4. Iridoviridae. 5. Frog vius 3. I.

Sousa, Ricardo Luiz Moro de, orient. II. Título. 


\section{CERTIFICADO}

Certificamos que a proposta intitulada "Clonagem e expressão da proteína MCP recombinante de isolado brasileiro de Ranavirus e produção de anticorpos policlonais anti-MCP", protocolada sob o CEUA no 2265041116 (ID 000491 ), sob a responsabilidade de Ricardo Luiz Moro de Sousa e equipe; Thaís Camilo Corrêa - que envolve a produção, manutenção e/ou utilização de animais pertencentes ao filo Chordata, subfilo Vertebrata (exceto o homem), para fins de pesquisa científica ou ensino - está de acordo com os preceitos da Lei 11.794 de 8 de outubro de 2008, com o Decreto 6.899 de 15 de julho de 2009, bem como com as normas editadas pelo Conselho Nacional de Controle da Experimentação Animal (CONCEA), e foi aprovada pela Comissão de Ética no Uso de Animais da Faculdade de Zootecnia e Engenharia de Alimentos da Universidade de São Paulo - FZEA/USP (CEUA/FZEA) na reunião de 15/03/2017.

We certify that the proposal "Cloning and expression of recombinant MCP protein in the Brazilian isolated Ranavirus and production of anti-MCP polyclonal antibodies", utilizing 2 Rabbits (2 males), protocol number CEUA 2265041116 (ID 000491 ), under the responsibility of Ricardo Luiz Moro de Sousa and team; Thaís Camilo Corrêa - which involves the production, maintenance and/or use of animals belonging to the phylum Chordata, subphylum Vertebrata (except human beings), for scientific research purposes or teaching - is in accordance with Law 11.794 of October 8, 2008, Decree 6899 of July 15, 2009, as well as with the rules issued by the National Council for Control of Animal Experimentation (CONCEA), and was approved by the Ethic Committee on Animal Use of the School of Animal Science and Food Engineering - (São Paulo University) (CEUA/FZEA) in the meeting of 03/15/2017.

Finalidade da Proposta: Pesquisa (Acadêmica)

Vigência da Proposta: de 07/2017 a 09/2017_Área: Medicina Veterinária

Origem: Cunicultura FZEA

Espécie: Coelhos sexo: Machos idade: 30 a 60 dias $\quad 2$

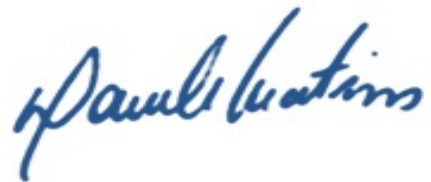

Profa. Dra. Daniele dos Santos Martins Coordenadora da Comissão de Ética no Uso de Animais Faculdade de Zootecnia e Engenharia de Alimentos da Universidade de São Paulo - FZEA/USP

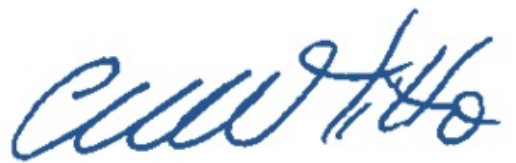

Profa. Dra. Cristiane Gonçalves Titto

Vice-Coordenadora da Comissão de Ética no Uso de Animais Faculdade de Zootecnia e Engenharia de Alimentos da Universidade de São Paulo - FZEA/USP 


\section{Universidade de São Paulo}

\section{ATA DE DEFESA}

Aluno: 74131 - $9691360-1 /$ Página 1 de 1

Ata de defesa de Tese do(a) Senhor(a) Thaís Camilo Corrêa no Programa: Zootecnia, do(a) Faculdade de Zootecnia e Engenharia de Alimentos da Universidade de São Paulo.

Aos 28 dias do mês de novembro de 2019, no(a) Sala de Defesas realizou-se a Defesa da Tese do(a) Senhor(a) Thaís Camilo Corrêa, apresentada para a obtenção do título de Doutora intitulada:

"Imunobiológicos para o diagnóstico laboratorial de ranavirose: clonagem e expressão do gene MCP de isolado brasileiro de Ranavirus e produção de anticorpos policlonais anti-proteína MCP recombinante"

Após declarada aberta a sessão, o(a) Sr(a) Presidente passa a palavra ao candidato para exposição e a seguir aos examinadores para as devidas arguições que se desenvolvem nos termos regimentais. Em seguida, a Comissão Julgadora proclama o resultado:

\begin{tabular}{|c|c|c|c|}
\hline Nome dos Participantes da Banca & Função & Sigla da CPG & Resultado \\
\hline Ricardo Luiz Moro de Sousa & Presidente & FZEA - USP & Jotante \\
\hline Hélio José Montassier & Titular & UNESP - Externo & \\
\hline Lara Borges Keid & Titular & FZEA - USP & \\
\hline Paulo Sérgio Monzani & Titular & Externo & \\
\hline Cláudia Maris Ferreira Mostério & Titular & Externo & log \\
\hline Mateus Maldonado Carriero & Titular & Externo & $a d a$ \\
\hline
\end{tabular}

Resultado rinal: Aprovada

Parecer da Comissão Julgadora *

Eu, Erica Cristina Mello Ferraz , lavrei a presente ata, que assino juntamente com os(as) Senhores(as). Pirassununga, abs 28 dias do mês de novembró de 2019
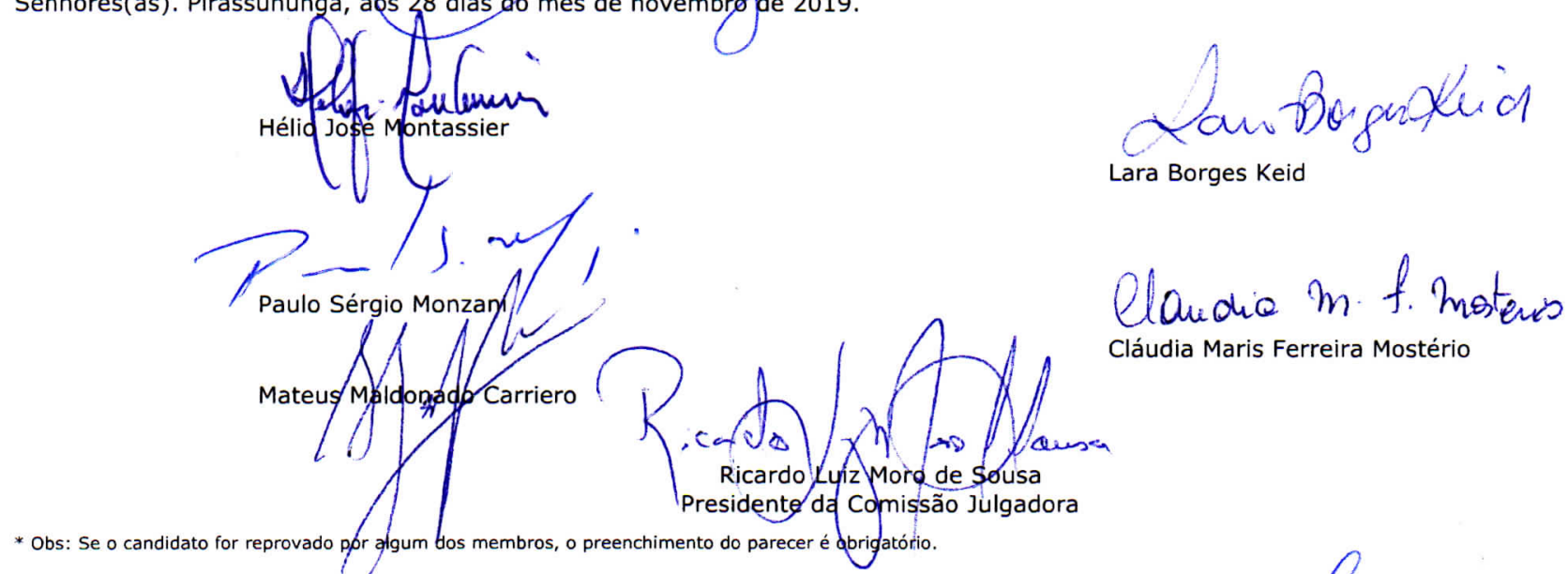

Cláudia Maris Ferreira Mostério

A defesa foi homologada pela Comissão de Pós-Graduação em 0212.2019 e, portanto, o(a) aluno(a) Doutora em Ciências obtido no Programa Zootecnia - Área de concentracão: Qutalidade e Produtividade Aningal.

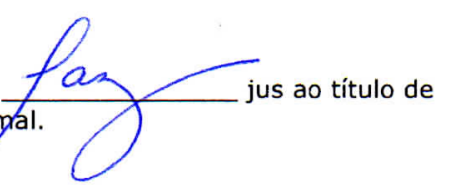

Presidente da Comissãó de Pós-Graduação

$$
\begin{gathered}
\text { Prof. Or. Rosemary Aparecida de Carvalho } \\
\text { Presidente da Comissajo de } \\
\text { Pos-Graduaçá } \\
\text { FeEsyc? }
\end{gathered}
$$




\section{DEDICATÓRIA}

Dedico esta tese ao meu sobrinho Pedro, que a curiosidade e a vontade de aprende que move todo cientista, nunca perca o brilho nos seus olhos. 


\section{AGRADECIMENTOS}

À minha Família, por ser meu porto seguro. Minha querida e amada mãe, Maria, por ser essa fortaleza que une a família inteira. Às minhas irmãs, Valéria e Juliana, pelo amor e amizade, além de me presentearem com meus sobrinhos lindos: Pedro, Clara e Helena. Ao meu pai, Alcides, em memória, por me ensinar ser honesta e fazer tudo nessa vida da melhor forma possível. Ao meu companheiro de vida, Wellington, o Adriano, por me dar suporte, apoio, amor e por toda paciência. Aos nossos filhos de patas, Fera e Rex, pelo amor puro e verdadeiro. Amo todos vocês!

Ao Prof. Dr. Ricardo Luiz Moro de Sousa, pela oportunidade, orientação, amizade, carinho, confiança, paciência, por sempre estar com a porta aberta para nos ouvir e apoiar. Muito obrigada por nunca me deixar desistir e resgatar todos os dias minha fé. Além de compartilhar sua paz e conhecimento, contribuindo para meu crescimento científico, intelectual e pessoal. Aproveito para agradecer à Cecilia, Francisco e Frederico.

À Fundação de Amparo à Pesquisa do Estado de São Paulo - FAPESP (processo $\mathrm{n}^{\circ}$ 2017/01356-4) pela concessão da bolsa de doutorado e pelo apoio financeiro para a realização desta pesquisa.

À Coordenação de Aperfeiçoamento de Pessoal de Nível Superior CAPES, pelo apoio à pesquisa brasileira, pela bolsa Demanda Social (DS) e custeios do Programa de Apoio à Pós-Graduação (PROAP).

À Profa. Dra. Andrezza Maria Fernandes, pela confiança e amizade, obrigada por abrir as portas da FZEA e me apresentar ao Prof. Ricardo.

À Dra. Sabrina Ribeiro de Almeida Queiroz e sua empresa, Dizoo Serviços de Atividades Veterinárias EIRELI-ME, juntamente com o PIPE - FAPESP (201621357-2), pela parceria e contribuição financeira para a realização do trabalho.

Ao Laboratório de Higiene Zootécnica e Multiusuário de Microbiologia, pela estrutura, ambiente saudável e suporte na realização do trabalho. À Faculdade de Zootecnia e Engenharia de Alimentos - FZEA/USP e ao Programa de Pós-Graduação em Zootecnia pela oportunidade de realização do curso doutorado.

Aos membros da banca de qualificação: Prof. Dr. Antonio Augusto Mendes Maia e Profa. Dra. Valéria Maria Lara Carregaro, pelas correções e contribuições.

Aos pesquisadores e pós-graduandos que de alguma forma contribuíram para a realização do trabalho: Dr. Paulo Sergio Monzani, Dr. George Shigueki Yasui, 
Dra. Cláudia Maris Ferreira Mostério, Dr. Mateus Maldonado Carriero, Dr. Nycolas Levy Pereira e Dr. Juliano Rodrigues Sangalli.

Ao Laboratório Max Feffer de Genética de Plantas - ESALQ/USP, coordenado pelo Prof. Dr. Carlos Alberto Labate, pelo acolhimento e ensinamentos durante a realização da espectrometria de massas.

Às especialistas de laboratório pelos quais passei para a realização de alguma etapa ou utilização de algum equipamento: Silvana Marina Piccoli Pugine, Cibele Maria Prado Zinni, Márcia Ramos Monteiro da Silva, Thaís Regiani Cataldi (ESALQ).

Aos funcionários da FZEA/USP, em especial: Érica C. M. Ferraz, Maria Cecilia Albernaz e toda a equipe do Serviço de Pós-Graduação, pela atenção e dedicação. À Jose Roberto Balduino da Silva (Beto) e Jose Roberto Boteon da cunicultura, por cuidarem dos coelhos do experimento. À Vanessa Rodrigues e os demais bibliotecários, pelos cursos e correções da tese.

À melhor técnica de laboratório, a do nosso, Silvia Helena Seraphin de Godoy, pela amizade, ajuda e Feng Shui na organização do Lab.

Aos meus colegas de laboratório: Amanda, Carol, Euder, Gabriela, Jenny, Juliana, Marcela, Maria Fernanda, Marina, Milena, Renata, Tatiana. Em especial Bárbara Silva Vignato, pela amizade, ajuda e conversas descontraídas durante as corridas de SDS-PAGE; Marisa Matias de França, pela amizade e melhores tiradas, Marcelo Felisberto dos Reis, pela amizade e ser meu copiloto; e Waldelucy Karina Bomfim Felix da Silva, pela amizade, conversas cabeça e a "nordestinizada" que faltada no meu vocabulário.

À minhas grandes amigas e parceiras, Loiane Sampaio Tavares e Samara Rita de Lucca Maganha, por toda ajuda com as células, pelas inúmeras horas de trabalho, pelos "minutos" de desabafo, pelas palavras de apoio e consolo, pelas correções, pelos muitos momentos de alegrias, dancinhas, rolês de comida e amizade. Pra sempre no meu coração!

Às minhas amigas "do exterior" Anna Luiza Farias Alencar e Andrea Vásquez Garcia, pela amizade, apoio, conversas sem fim via Whats. Vocês tornam meus dias mais leves. Déia, sempre com uma análise precisa e sincera de todas as situações; Annie, sempre com uma história ou treta engraçada. 
Aos meus amigos que desde a graduação fazem parte da minha vida, Karina Pádua e Haroldo Cesar de Oliveira, muito obrigada pelo apoio e sempre estarem por perto.

Aos alunos de Iniciação Científica: Aline, Erika, Isabela, Paula e Odacir, por me possibilitarem desenvolver minhas habilidades de orientação e paciência, obrigada pela amizade.

Ao Paulo Sérgio Ceccarelli e César Polettini pela doação das tilápias, e apoio nos nossos trabalhos paralelos.

Ao meu assessor da FAPESP pelas correções dos relatórios e por sua avaliação no parecer inicial, que sempre me acompanhou "...pois todas as etapas precisam de padronização, o que pode não ocorrer no tempo previsto...". Realmente, apanhei e atrasou um pouquinho.

Ao terapeuta Eduardo Baiocco Cellim e ao psiquiatra da FZEA/USP Dr. Wagner Shigueru Matsuzaki, por todo apoio e ajuda no momento de maior loucura/dificuldade da minha vida. As minhas fisioterapeutas maravilhosas, Ivana Nogueira e Sandra Azarite, por toda amizade e ajuda no combate as minhas dores.

A todos de que contribuíram para minha jornada, meu muito OBRIGADA! 
"Eu sou aquela mulher a quem o tempo muito ensinou.

Ensinou a amar a vida e não desistir da luta, recomeçar na derrota, renunciar a palavras e pensamentos negativos. Acreditar nos valores humanos e ser otimista."

Cora Coralina 


\section{RESUMO}

CORREAA, T. C. Imunobiológicos para o diagnóstico laboratorial de ranavirose: clonagem e expressão do gene MCP de isolado brasileiro de Ranavirus e produção de anticorpos policlonaisanti-proteína MCP recombinante. 2019. 131f. Tese (Doutorado) - Faculdade de Zootecnia e Engenharia de Alimentos, Universidade de São Paulo, Pirassununga - SP, 2019.

Membros do gênero Ranavirus, pertencente à família Iridoviridae, têm sido responsáveis por epizootias em animais ectotérmicos em várias partes do mundo, pois representam patógenos emergentes capazes de infectar três classes de vertebrados: peixes ósseos, anfíbios e répteis. No Brasil, os relatos de surtos por ranavirose sassociados ao Frogvirus 3 (FV3) ocorrem desde meados dos anos 2000, sendo cada vez mais frequentes principalmente em criações comerciais de rã-touro. Portanto, as infecções por ranavírus representam um risco para outros setores da aquicultura, como a piscicultura. Neste contexto, visando a produção de imunorreagentes para uso em testes de diagnóstico, os objetivos foram: produzir a proteína recombinante do gene MCP (Major capsid protein) do isolado brasileiro de Ranavirus, FV3-símile; produzir anticorpos policlonais de coelho anti-rMCP e, por fim, padronizar um teste de ELISAIB (Indirect-Blocking Enzyme Linked Immunosorbent Assay). Para isso, foi construído o plasmídeo pET28a/MCP, transformado em Rosetta TM (DE3) para a expressão da proteína rMCP. Após a purificação, a produção de anticorpos policlonais anti-rMCP foi conduzida em dois coelhos jovens através de três inoculações da proteína rMCP, por via intramuscular e subcutânea, em intervalos de 14 dias, sendo os soros analisados por Immunoblot. Para a padronização do teste ELISA-IB, foram amostrados soros de rãstouro e realizada a infecção experimental de tilápias do Nilo, para a obtenção de soros controles. Destaque para os resultados com o sucesso da expressão da proteína rMCP de $50 \mathrm{kDa}$, no entanto, em sua forma insolúvel sob purificação desnaturante seguida de diálise. A rMCP desencadeou a produção de anticorpos policlonais nos coelhos, já na segunda imunização. No ELISA-IB, a proteína rMCP foi utilizada como antígeno viral, seguida dos soros testes e anticorpos de bloqueio (policlonal anti-rMCP). Contudo, problemas com a obtenção de soros controles adequados dificultaram a padronização do teste, sendo possível, no entanto, identificar porcentagem de inibição em soro de rã. $\mathrm{O}$ uso dos imunorreagentes produzidos e o ELISA-IB demostraram potencial promissor para o diagnóstico laboratorial de infecção por ranavírus em peixes, bem como anfíbios, no intuito de colaborar para a melhoria das condições sanitárias da aquicultura brasileira. Além disso, os imunorreagentes obtidos podem propiciarnovos estudos para a produção de imunógenos vacinais contra o Ranavirus.

Palavras-chave: ELISA-IB. FV3. Imunorreagentes. Iridovirus. Proteína recombinante. 


\begin{abstract}
CORREAA, T. C. Immunobiologics for the laboratory diagnosis of ranaviral infections: cloning and expression of the MCP gene from a Ranavirus Brazilian isolate and production of polyclonal antibodies against recombinant MCP protein. 2019. 131f. Tese (Doutorado) - Faculdade de Zootecnia e Engenharia de Alimentos, Universidade de São Paulo, Pirassununga - SP, 2019.

Members of the genus Ranavirus, belonging to the family Iridoviridae, have been responsible for epizootics in ectothermic animals in various parts of the world, as they represent emerging pathogens capable of infecting three classes of vertebrates: bony fish, amphibians and reptiles. In Brazil, reports of Frog virus 3 (FV3)-associated ranavirus outbreaks have occurred since the mid-2000s, and are increasingly common mainly in commercial bullfrog farming. Therefore, ranavirus infections pose a risk to other aquaculture sectors, such as fish farming. In this context, aiming at the production of immunoreagents for use in diagnostic tests, the objectives were: to produce the recombinant MCP (Major capsid protein) gene from the Brazilian Ranavirus isolate, FV3-like; produce rabbit anti-rMCP polyclonal antibodies and, finally, standardize an ELISA-IB (Indirect-Blocking Enzyme Linked Immunosorbent Assay) test. To this end, the Rosetta TM transformed plasmid pET28a / MCP (DE3) was constructed for the expression of the rMCP protein. Following purification, the production of polyclonal anti-rMCP antibodies was conducted in two young rabbits by three intramuscular and subcutaneous immunizations with the rMCP protein at 14-day intervals and the sera analyzed by Immunoblot. For standardization of the ELISA-IB test, bullfrog sera were sampled and experimental infection of Nile tilapia was carried out to obtain control sera. It is worth mentioning for the results, the successful expression of the $50 \mathrm{kDa} \mathrm{rMCP}$ protein, however, in its insoluble form, under denaturing purification followed by dialysis. The rMCP triggered the production of polyclonal antibodies in rabbits as early as the second immunization. In ELISA-IB, rMCP protein was used as viral antigen, followed by sera tests and blocking antibodies (anti-rMCP polyclonal). However, problems with obtaining adequate control sera made the standardization of the test difficult, but it was possible to identify inhibition percentage in frog serum. The use of the produced immunoreagents and the ELISA-IB show promising potential for laboratory diagnosis of ranavirus infection in fish, as well as amphibians, in order to contribute to the improvement of sanitary conditions in Brazilian aquaculture. In addition, the obtained immunoreagents may provide further studies for the production of vaccine immunogens against Ranavirus.
\end{abstract}

Keywords: ELISA-IB. FV3. Immunoreagents. Iridovirus. Recombinant protein. 


\section{LISTA DE FIGURAS}

Figura 1 - Mapa da distribuição global de casos de Ranavirus................................28

Figura 2 - Esquematização da estrutura do vírion................................................. 31

Figura 3 - Ciclo da replicação viral dos Ranavirus....................................................35

Figura 4 - Filogenia dos Ranavirus com base na evolução dos hospedeiros do gênero.

Figura 5 - Imagens de microscopia eletrônica de transmissão da linhagem celular BF2 infectada com FV3-símile, um isolado brasileiro. .40

Figura 6 - Distribuição de Ranavirus no Brasil, segundo registros da literatura consultada.......

Figura 7 - Representação esquemática de modelos de ELISA.................................43

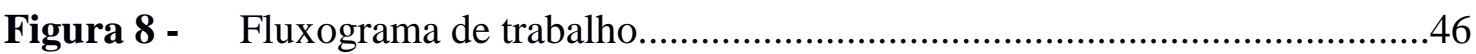

Figura 9 - Mapa o vetor de clonagem e expressão pET SUMO.

Figura 10 - Representação da expressão de proteína recombinante a partir da indução

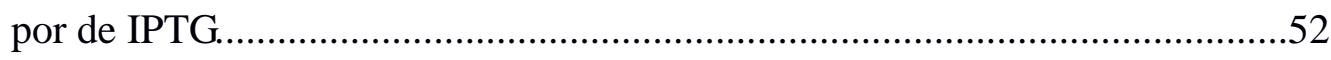

Figura 11 - Mapa do vetor expressão pET28a(+) DNA..............................................53

Figura 12 - Representação esquemática do ELISA, na padronização do anticorpo de bloqueio. .72

Figura 13 - Representação esquemática do ELISA-IB, na avaliação dos soros teste. .73

Figura 14 - Células BF-2 infectadas por FV3-símile. .76

Figura 15 - Amplificação do gene MCP do isolado FV3-símile e controles da reação de PCR......

Figura 16 - Ligação e transformação da E. coli OneShot ${ }^{\circledR} \operatorname{Mach}^{\mathrm{TM}}-\mathrm{T} 1^{\mathrm{R}}$ . .78

Figura 17 - Verificação da presença do gene MCP no vetor recombinante. .79

Figura 18 - Sequência de nucleotídeos de um dos clones evidenciando a inserção do gene MCP na posição correta de leitura e expressão da proteína fusionada.....80

Figura 19 - Alinhamento entre as sequências deduzidas de aminoácidos do gene MCP.......

Figura 20 - Caracterização por SDS-PAGE da proteína rMCP da expressão a $37^{\circ} \mathrm{C} . .85$

Figura 21 - Caracterização por SDS-PAGE da proteína rMCP da expressão a $22^{\circ} \mathrm{C} . .85$ 
Figura 22 - Caracterização por WB da proteína rMCP da expressão a $37^{\circ} \mathrm{C}$ e $22^{\circ} \mathrm{C} . .86$

Figura 23 - Amplificação do gene MCP de FV3-símile utilizando Pet28MCP-F e Pet28MCP-F .87

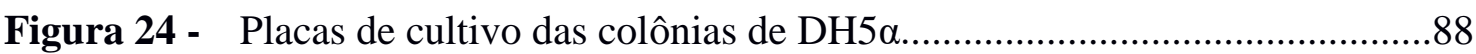

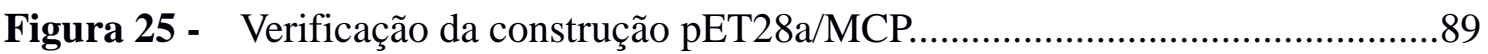

Figura 26 - Caracterização por SDS-PAGE e WB da proteína rMCP no piloto de expressão com o vetor pET-28a/MCP nas duas linhagens de expressão. .91

Figura 27 - Gel de poliacrilamida representando as bandas que foram excisadas para recuperação dos peptídeos e realização $\mathrm{LC}-\mathrm{MS}^{\mathrm{E}}$.

Figura 28 - Representação do sequenciamento proteico realizado por espectrometria de massa. .93

Figura 29 - Diálise da proteína rMCP após a purificação desnaturante .96

Figura 30 - WB da proteína rMCP purificada. .96

Figura 31 - Purificação da proteína rMCP pela Talon ${ }^{\circledR}$ Superflow $^{\mathrm{TM}}$ e SDS-PAGE...97

Figura 32 - Procedimento anestérico e colheita de sangue. .98

Figura 33 - Immunoblot para avaliação da produção de anticorpos policlonais antirMCP. .98

Figura 34 - Procedimento de inoculação e colheita de sangue. .99

Figura 35 - Gel de agarose da PCR com os marcadores moleculares: MCP e ORF53R(1) 100

Figura 36 - Fotomicrografia de órgãos de tilápia. Grupo controle negativo (sem inoculação do FV3-símile) e grupo controle positivo (indivíduos inoculados com FV3-símile). 101

Figura 37 - Exemplificação da coloração da placa de ELISA nas leituras de DO por espectrometria 102 


\section{LISTA DE TABELAS}

Tabela 1 - Panorama mundial de produção por captura, aquicultura e utilização.....22

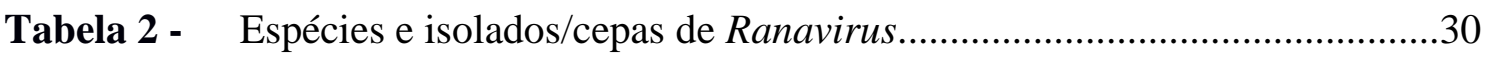

Tabela 3 - Principais genes da família Iridoviridae. As designações das ORFs são baseadas em suas posições dentro do genoma do FV3 (AY548484).................32

Tabela 4 - Sequências depositadas no GenBank utilizadas para desenho de novo oligonucleotídeo. .47

Tabela 5 - Proporção de aminoácidos da proteína MCP do FV3-símile. Códons raros em E. coli e os observados no gene MCP......

Tabela 6 - Valores de DO observados no ELISA-IB de soros de peixe....................103

Tabela 7 - Valores da porcentagem de inibição dos soros de peixes..........................104

Tabela 8 - Valores das DO observadas para o cálculo da DOMÁx............................105

Tabela 9 - Valos de DO observadas no ELISA-IB do soro de anfíbios....................105

Tabela 10 - Valores da porcentagem de inibição dos soros de anfíbios.......................106 
LISTA DE ABREVIATURAS E SIGLAS

Símbolo dos aminoácidos

\section{Nome do aminoácido}

Alanina

Arginina

Asparagina

Aspartato

Cisteína

Glutamina

Ácido glutâmico

Glicina

Histidina

Isoleucina

Leucina

Lisina

Metionina

Fenilalanina

Prolina

Serina

Treonina

Triptofano

Tirosina

Valina
Código 3 letras

Ala

Arg

Asn

Asp

Cys

Gln

Glu

Gly

His

Ile

Leu

Lys

Met

Phe

Pro

Ser

Thr

Trp

Tyr

Val
Código 1 letra

A

R

$\mathrm{N}$

D

C

Q

E

G

$\mathrm{H}$

I

L

K

M

F

P

S

$\mathrm{T}$

W

Y

V
Ac

AV

BF-2

Blast

BSA

CAT

$\mathrm{CO}_{2}$

DNA
Antígeno controle

Antígeno viral

Bluegillfry - linhagem celular

Basic Local Alignment Search Tool

Bovineserumalbumin (Albumina de soro bovino)

Cloranfenicol Acetil Transferase

Dióxido de Carbono

Ácido desoxirribonucleico 
dsDNA

DO

DOMÁx

$\mathrm{DO}_{\mathrm{NEG}}$

DOPOS

DO

DTT

ECP

eDNA

ELISA

ELISA-IB

EUA

FAO

FV3

GenBank

GRC

GRRS

IBGE

ICTV

$\mathrm{IgG}$

IgM

IPTG

LAMP

$\mathrm{LC}^{-M S^{\mathrm{E}}}$

M

MAPA

MCP

MEM

$\mathrm{mM}$

MS/MS

N

NCBI

NCLDVs

OIE
Double stranded DNA virus

Densidade óptica

Densidade óptica máxima

Densidade óptica controle negativos

Densidade óptica controle positivos

Densidade óptica da amostra

Ditiotreitol

Efeito citopático

EnvironmentalDNA

Enzyme Linked Immunosorbent Assay

Indirect-Blocking ELISA

Estados Unidos da América

Organização das Nações Unidas para Alimentação e Agricultura

Frog virus 3

Banco de dados de anotações de sequencias de nucleotídeos doNCBI

Global Ranavirus Consortium

Global Ranavirus Reporting System

Instituto Brasileiro de Geografia e Estatística

International Committe on Taxonomy of Viruses

Imunoglobulina $\mathrm{G}$

Imunoglobulina $\mathrm{M}$

Isopropyl $\beta$-D-1-thiogalactopyranoside

Loop-mediated isothermal amplification

Cromatografia líquida com espectrômetro de massa

Molar

Ministério da Agricultura, Pecuária e Abastecimento

Major capsid protein (Proteína principal do capsídeo)

Minimum Essential Medium

Milimolar

Espectrometria de massa em tandem

número amostral

National Center for Biotechnology Information

Nucleo-CytoplasmicLarge DNA Viruses

Organização Mundial da Saúde Animal 
OMS

ORF

ONU

PI

PBS

PBS-T

PCR

qPCR

RIF

SDS-PAGE

SFB

TAE

$\mathrm{TCID}_{50}$

TBS

TBS-T

TMB

WB
Organização Mundial da Saúde

Open Reading Frame

Organização das Nações Unidas

Porcentagem de inibição

Tampão fosfato-salino

Tampão fosfato-salino com Tween 20

Reação em cadeia pela polimerase

Quantitative real-time PCR

Reações de imunofluorescência indireta

Sodium Dodecyl Sulphate - Polyacrylamide Gel Electrophoresis

Soro fetal bovino

Tampão Tris-Acetato-EDTA

Tissue Culture Infective Dose 50\%

Tris Buffered Saline

Tris Buffered Saline with Tween 20

3,3',5,5'-Tetramethylbenzidine

Western Blot 


\section{LISTA DE SÍMBOLOS}

$\begin{array}{ll}\sim & \text { Aproximadamente } \\ { }^{\circ} \mathrm{C} & \text { Graus Celsius } \\ \pm & \text { Mais ou menos } \\ \% & \text { Porcentagem } \\ \mu \mathrm{g} & \text { micrograma } \\ \mu \mathrm{L} & \text { Microlitro } \\ \mathrm{g} & \text { Grama } \\ g & \text { Unidade de aceleração, equivalente a 9,80665 m/s² } \\ \mathrm{kDa} & \text { Kilodalton } \\ \mathrm{kg} & \text { Quilograma } \\ \mathrm{mL} & \text { Mililitro } \\ \mathrm{mm} & \text { Milímetro } \\ \mathrm{nm} & \text { Nanômetro } \\ \text { Overnight } & \text { 16 a 18 horas } \\ \mathrm{pb} & \text { Pares de base } \\ \mathrm{pH} & \text { Potencial Hidrogeniônico } \\ \mathrm{p} / \mathrm{v} & \text { Peso/volume } \\ \mathrm{q} \cdot \mathrm{s} \cdot \mathrm{p} & \text { Quantidade suficiente para } \\ \mathbb{R} & \text { Registrado } \\ \mathrm{T} & \text { Toneladas } \\ \mathrm{TM} & \text { Trade Mark } \\ & \end{array}$




\section{SUMÁRIO}

1 INTRODUÇÃ

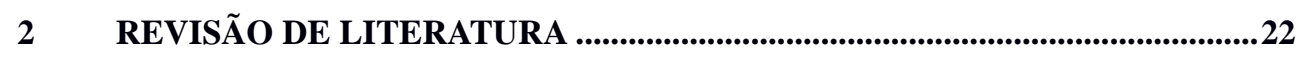

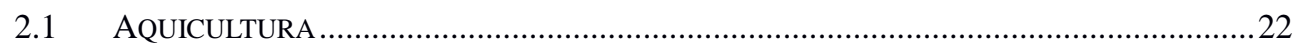

2.2 FAMÍLIA IRIDOVIRIDAE ................................................................................25

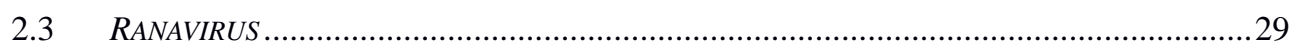

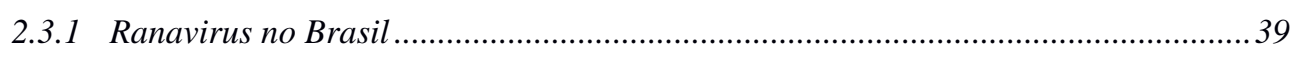

2.4 TESTES DE DIAGNóstico................................................................................. 42

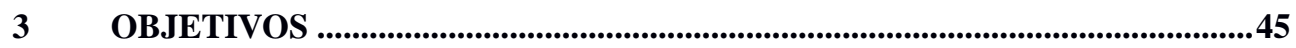

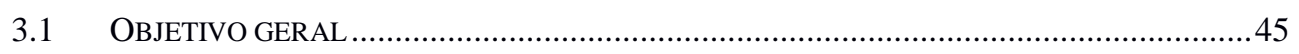

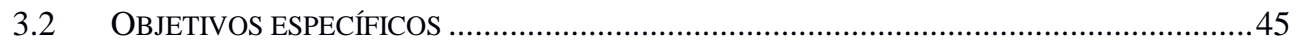

4 MATERIAL E MÉTODOS .........................................................................46

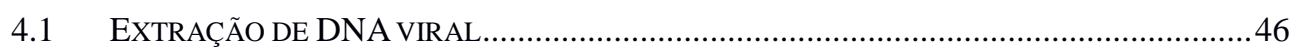

4.2 REAÇÃO EM CADEIA DA POLIMERASE (PCR) ....................................................... 47

4.3 CLONAGEM E EXPRESSÃo DO GENE MCP NO VETOR PET-SUMO................................48

4.3.1 Ligação e transformação em One Shot ${ }^{\circledR}$ Machl TM-T1R ….........................................49

4.3.2 Análise dos clones recombinantes por PCR e sequenciamento .................................50

4.3.3 Transformação na E. coli de expressão BL21(DE3) One Shot ${ }^{\circledR}$.................................51

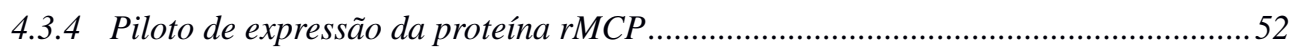

4.4 CLONAGEM E EXPRESSÃo NOS VETORES PGEM ${ }^{\circledR}$-T E PET28A (+)..............................53

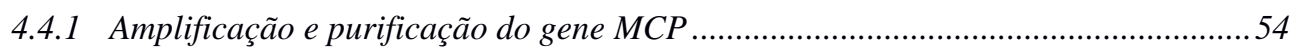

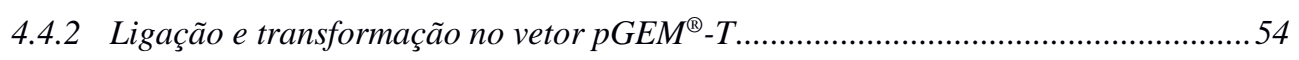

4.4.3 Digestão enzimática, ligação e transformação no vetor de expressão pET28a(+) ..55

4.4.4 Transformação em duas linhagens de E. coli e expressão da proteína rMCP...........56

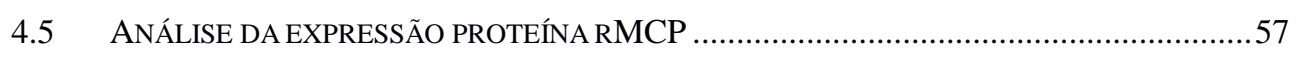

4.5.1 SDS-PAGE (Sodium Dodecyl Sulphate - Polyacrylamide Gel Electrophoresis)......57

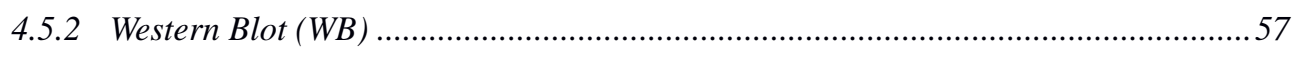

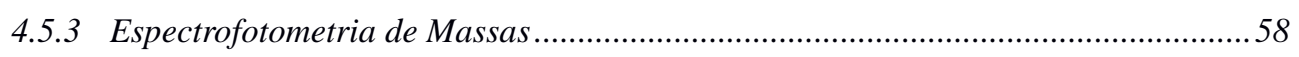

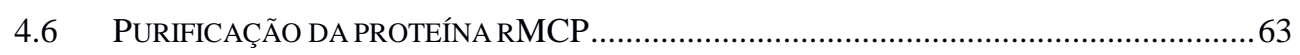

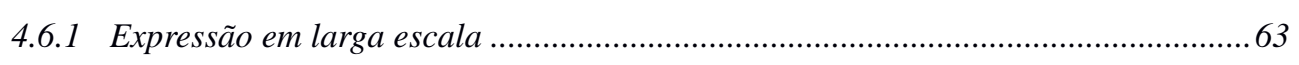

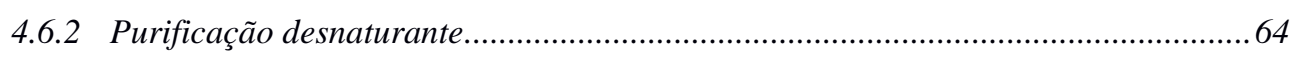

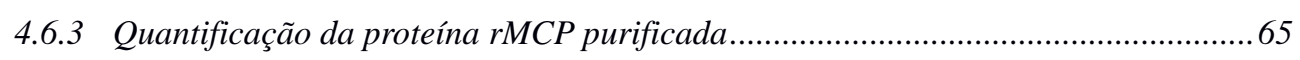

4.7 PRODUÇão DE ANTICORPOS POLICLONAIS ANTI-RMCP ..............................................66

4.7.1 Avaliação do título dos antissoros por Immunoblot..................................................66

4.8 PRODUÇão DE SOROS CONTROLES EM TILÁPIAS (OREOCHROMIS NILOTICUS) ..............67

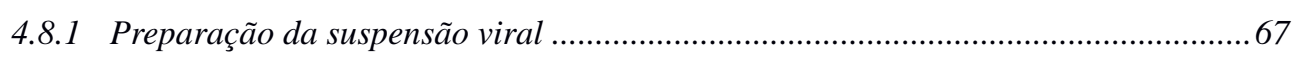

4.8.2 Manejo das tilápias e inoculação ...................................................................6

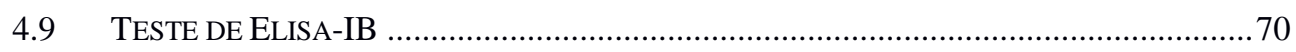


4.9.1 Padronização do anticorpo de bloqueio - anticorpo policlonal anti-rMCP ............. 70

4.9.2 Padronização do Elisa-IB através da titulação dos soros de tilápias .......................72

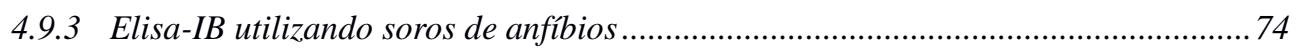

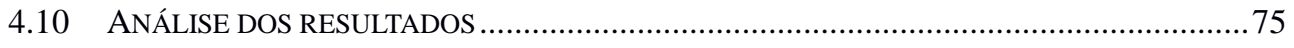

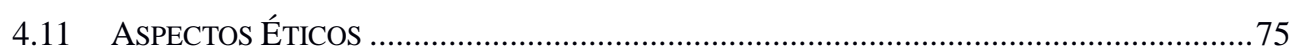

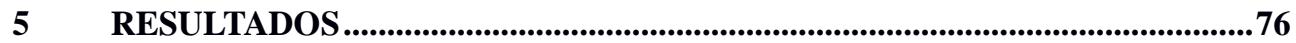

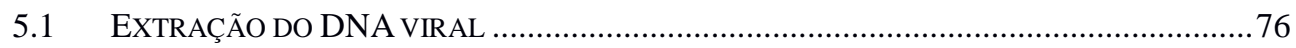

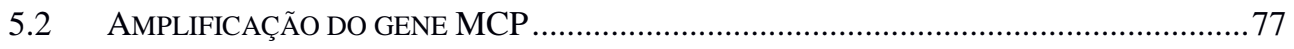

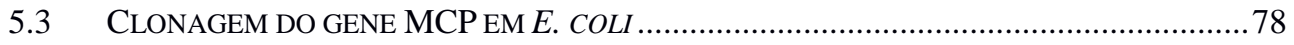

5.3.1 Ligação e transformação na linhagem One Shot ${ }^{\circledR}$ Mach $1^{\mathrm{TM}_{-}} \mathrm{T}^{R}{ }^{\mathrm{N}}$............................. 78

5.3.2 Análise dos clones recombinantes e dedução de aminoácidos do gene MCP ......... 79

5.4 ANÁLISE DA EXPRESSÃO COM O VETOR PET-SUMO DA PROTEÍNA RMCP POR SDSPAGE E WB

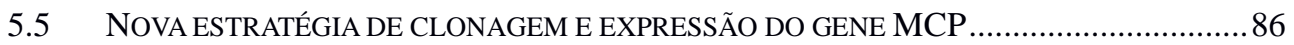

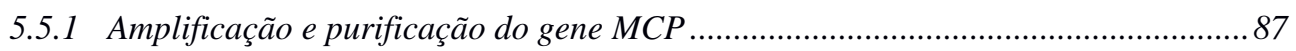

5.5.2 Clonagem no vetor nos vetores $p G E M^{\circledR}{ }_{-}$T e pET28a (+) DNA …............................ 87

5.6 ANÁLISE DA NOVA EXPRESSÃO PROTEÍNA RMCP ..................................................90

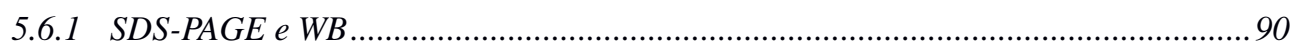

5.6.2 Espectrofotometria de Massas .............................................................................. 92

5.7 PURIFICAÇÃO E QUANTIFICAÇÃO DA PROTEÍNA RMCP ...............................................95

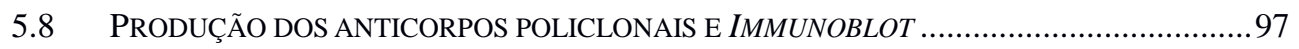

5.9 PRODUÇÃO DE SOROS CONTROLE POR INFECÇÃO EXPERIMENTAL EM TILÁPIAS...........99

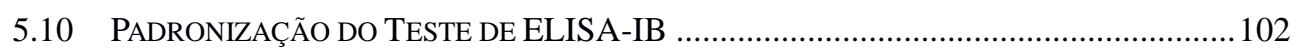

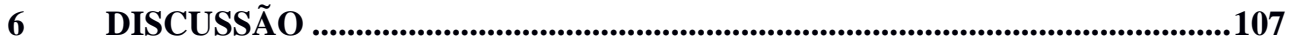

7 CONCLUSÃ

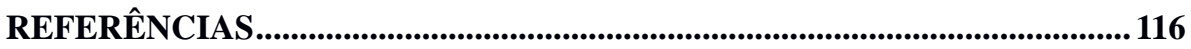

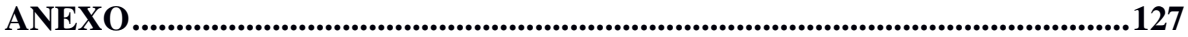




\section{INTRODUÇÃO}

Os membros da família Iridoviridae têm sido responsáveis por epizootias de grandes impactos ecológicos e econômicos em peixes, anfíbios e répteis de várias partes do mundo. A família compreende vírus núcleo-citoplasmáticos grandes de DNA (NCLDVs), ou seja, de cadeia dupla de DNA (dsDNA) e capsídeo icosaédrico. Duas subfamílias compõem esta família, Alphairidovirinae e Betairidovirinae. A primeira subfamília é composta pelos gêneros: Ranavirus, Lymphocystivirus e Megalocytivirus, que infectam vertebrados ectotérmicos. Enquanto, Lymphocystivirus e Megalocytivirus infectam apenas peixes, o gênero Ranavirus contêm espécies que infectam peixes, répteis e anfíbios, sendo Ranavirus e Megalocytivirus notoriamente reconhecidos por causar alta mortalidade em muitas espécies de peixes de interesse econômico. A segunda subfamília é composta por dois gêneros: Iridovirus e Chloriridovirus, que infectam invertebrados, como insetos e crustáceos.

Ranaviroses já foram identificadas nas Américas, Europa, Ásia e Oceania tanto em criações aquícolas quanto em populações selvagens, causando alta mortalidade e morbidade. Os ranavírus são classificados como agentes patogênicos emergentes, devido a ampla distribuição geográfica e gama de hospedeiros, parâmetros que parecem estar se expandindo principalmente com a maior atenção que o gênero Ranavirus têm recebido nas últimas décadas, em decorrência, sobretudo, do aumento dos relatos de propagação rápida e alta letalidade das infecções associadas a vírus desse gênero. A Organização Mundial de Saúde Animal (World Organisation for Animal Health - OIE) reconhece um ranavírus, EHNV (vírus da necrose hematopoiética epizoótica), como um patógeno de notificação obrigatória para peixes, enquanto para anfíbios todas as infecções causadas por ranavírus são de notificação obrigatória a OIE.

No Brasil, as informações sobre a ocorrência de infecções em peixes causadas por ranavírus são limitadas a apenas dois trabalhos: o ranavírus Frog virus 3 (FV3) foi identificado em tilápias do Nilo (Oreochromis niloticus) em surtos sequenciais de mortalidade no Ceará e em uma tilápia criada próximo a ranários em Goiás; e em pacu vermelho (tambaqui) (Colossoma macropomum), oriundo de uma propriedade com a presença de ranicultura no estado de São Paulo. Por outro lado, desde meados dos anos 2000, vem sendo reportado que o FV3 é o vírus que circula no país, provocando surtos principalmente em raniculturas. 
A aquicultura é uma atividade zootécnica em expansão, pois a produção de pescado por captura se mantém estável ao longo das últimas décadas em função da redução dos estoques naturais. Portanto, a aquicultura é apontada como um mercado estratégico para o desenvolvimento sustentável da produção de alimentos, principalmente para o Brasil, que figura entre os maiores produtores do mundo, atingindo a casa dos $\mathrm{R} \$ 4,7$ bilhões no último levantamento. Entretanto, assim como outros sistemas de produção animal, a aquicultura enfrenta problemas com doenças resultantes de sua intensificação. Dessa forma, para contribuir com o aumento da produção, a aquicultura depende de uma série de melhorias na cadeia produtiva incluindo práticas de manejo, rações de qualidade, melhoramentos genético e sanitário.

Neste contexto, diante da escassez de informações sobre a ocorrência de Ranavirus em peixes no Brasil, a importância da aquicultura para a produção zootécnica brasileira e um possível impacto econômico provocado por doenças infecciosas do gênero Ranavirus, são oportunas as pesquisas que visam diagnosticar doenças infecciosas que afetam os animais em ambientes de cultivo, visto que os patógenos virais são considerados uma das causas de perda econômica na aquicultura mundial. Na tentativa de contribuir com a mitigação desse problema, a hipótese deste projeto é que a proteína recombinante e os soros policlonais produzidos a partir da variante brasileira de Ranavirus, FV3-símile, possibilitem a produção de imunorreagentes para um teste ELISA Indireto de bloqueio (ELISA-IB). 


\section{REVISÃO DE LITERATURA}

\subsection{Aquicultura}

A aquicultura é definida como criação de espécies aquáticas em sistemas controlados ou semicontrolados, visando aumentar a produtividade de alimentos. Esta atividade zootécnica possibilita produtos mais homogêneos, rastreabilidade da cadeia produtiva e demais vantagens que contribuem para a segurança alimentar; dessa forma, gera um alimento de qualidade, com planejamento, regularidade e de forma mais sustentável que as atividades extrativistas (FAO, 2014; SIQUEIRA, 2017). A aquicultura é subdividida em algumas especialidades, como piscicultura (criação de peixes), ranicultura (criação de rãs), carcinicultura (criação de caranguejos, camarões, lagostas), malacocultura (criação de moluscos), algicultura (cultivo de algas) e a criação de répteis (jacaré e quelônios).

A aquicultura é uma atividade em expansão, pois a produção de pescado por captura se mantém estável desde o final da década de 1980, em função da redução dos estoques naturais. Segundo o relatório da FAO, até o ano de 2013, cerca de $90 \%$ dos estoques naturais de pescados foram explorados acima de seus limites sustentáveis (FAO, 2016). A produção aquícola mundial tem aumentado substancialmente de menos de 1 milhão de toneladas (t) na década de 50 para 80 milhões de toneladas em 2016 (BUENO et al., 2015; FAO 2016) (Tabela 1).

Tabela 1 - Panorama mundial de produção por captura, aquicultura e utilização.

\begin{tabular}{|c|c|c|c|c|c|c|}
\hline Calegory & 2011 & 2012 & 2013 & 2014 & 2015 & 2016 \\
\hline \multicolumn{7}{|l|}{ Production } \\
\hline \multicolumn{7}{|l|}{ Capture } \\
\hline Inland & 10.7 & 11.2 & 11.2 & 11.3 & 11.4 & 11.6 \\
\hline Marine & 81.5 & 78.4 & 79.4 & 79.9 & 81.2 & 79.3 \\
\hline Total capture & 92.2 & 89.5 & 90.6 & 91.2 & 92.7 & 90.9 \\
\hline \multicolumn{7}{|l|}{ Aquaculture } \\
\hline Inland & 38.6 & 42.0 & 44.8 & 46.9 & 48.6 & 51.4 \\
\hline Marine & 23.2 & 24.4 & 25.4 & 26.8 & 27.5 & 28.7 \\
\hline Total aquaculture & 61.8 & 66.4 & 70.2 & 73.7 & 76.1 & 80.0 \\
\hline Total world fisheries and aquaculture & 154.0 & 156.0 & 160.7 & 164.9 & 168.7 & 170.9 \\
\hline \multicolumn{7}{|l|}{ Utilization $^{\mathrm{b}}$} \\
\hline Human consumption & 130.0 & 136.4 & 140.1 & 144.8 & 148.4 & 151.2 \\
\hline Non-food uses & 24.0 & 19.6 & 20.6 & 20.0 & 20.3 & 19.7 \\
\hline Population (billions) & 7.0 & 7.1 & 7.2 & 7.3 & 7.3 & 7.4 \\
\hline Per capita apparent consumption (kg) & 18.5 & 19.2 & 19.5 & 19.9 & 20.2 & 20.3 \\
\hline
\end{tabular}

Legenda: Valores em milhões de toneladas. Fonte: FAO 2018. The State of World Fisheries and Aquaculture 2018 - Meeting the sustainable development goals. Rome. p.4. 
A Organização Mundial da Saúde (OMS) recomenda que a população consuma pescado ao menos duas vezes por semana e que o consumo seja de 12 $\mathrm{kg} / \mathrm{hab} / \mathrm{ano}$. O consumo per capta mundial foi em média de 9,9 kg/ano na década de 60, de 14,4 kg/ano na década de 90 e, alcançou um recorde de 20,3 kg/ano em 2016; e ainda, tem como projeções atingir o consumo de 21,8 kg/ano em 2025. Entretanto, o consumo per capita ainda é muito desigual entre as populações, analisando por continentes; por exemplo, alguns deles ultrapassam a média mundial per capita: Ásia, $24 \mathrm{~kg} / \mathrm{ano}$ e Europa, 22,5kg/ano; outros ficam bem abaixo da média mundial e o recomendado pela OMS, como exemplo: África, 9,9 kg/ano e América Latina e Caribe, 9,8kg/ano (FAO, 2018). No Brasil, o consumo per capta está abaixo de $10 \mathrm{~kg} / \mathrm{ano}$, além disso, este consumo também difere entre as regiões do país (PEIXE BR, 2019).

Entretanto, no Brasil, a aquicultura é vista como um mercado estratégico para o desenvolvimento sustentável, produção de proteínade qualidade e ampliação de fronteiras inexploradas no país. Diante de seu grande potencial em água doce (mais de $12 \%$ da água do planeta) extensa costa (aproximadamente 8,5 mil quilômetros), clima e geografia favoráveis e diversificados, rica biodiversidade tanto no mar quanto nos rios e lagoas, e significativa produção de grãos para fabricaçãode ração (ACEB, 2014; FIGUEIREDO; LEAL, 2008).

No levantamento da FAO em 2014, o Brasil figurava como o $14^{\circ}$ país dos 25 maiores produtores aquícolas do mundo (FAO 2016). Em 2016, atingiu um valor de produção de $\mathrm{R}$ \$ 4,61 bilhões, com cerca de 70,9\% oriunda da criação de peixes, seguida pela criação de camarões com 19,3\% (IBGE, 2016). Comparada com outras atividades nacionais, a aquicultura apresenta resultados de crescimento superiores aos da pesca extrativista e também se sobressai com relação à produção de aves, suínos e bovinos (BOSCARDIN, 2008). Por exemplo, a piscicultura brasileira cresceu 4,5\% em 2018, produzindo 722.560 toneladas de peixes de cultivo, sobre as $691.700 \mathrm{t}$ do ano anterior, e já vinha de um crescimento de 8\% de 2016 para 2017 (PEIXE BR, 2019).

Como a principal modalidade da aquicultura desenvolvida no país é a criação de peixes de água doce, destaca-se a tilápia (O. niloticus) que atingiu $400.280 \mathrm{t}$ em 2018, com crescimento de 11,9\% em relação ao ano anterior. Por esse desempenho, a espécie representa $55,4 \%$ da produção total de peixes de cultivo, que neste momento tem a produção liderada pelo estado do Paraná. Os peixes nativos representam 39,84\% da produção total do país, com relevância aos peixes redondos, em Rondônia, com 
72.800 t, seguida pelo Mato Grosso com 52.000 t (PEIXE BR, 2019). Destacam-se também os híbridos tambacu e tambatinga, a carpa (Cyprinus carpio), os peixes de couro (Pseudoplatystoma sp.), o pacu (Piaractus mesopotamicus) e o matrinxã (Brycon sp.) (BUENO et al., 2015; IBGE, 2016).

Outra especialidade da aquicultura que vem crescendo no Brasil é a ranicultura, sua implantação ocorreu em 1935 com a importação de matrizes da espécie de rã-touro (Lithobates catesbeianus), oriundas da América do Norte, para o estado do Rio de Janeiro. Contudo, foi nas duas últimas décadas que essa atividade zootécnica ganhou destaque em vários estados da federação, como exemplo, Goiás, Santa Catarina e São Paulo. O crescimento do setor veio principalmente a partir dos adventos tecnológicos desenvolvidos ao longo dos anos, como aperfeiçoamento das instalações e das técnicas de manejo adotadas pelos produtores (CRIBB; AFONSO; MOSTÉRIO, 2013).

Os dados sobre a produção brasileira de rãs são escassos, uma vez que o censo de Produção da Pecuária Municipal do IBGE agrupa a ranicultura com a criação de jacaré, siri e caranguejo. Dessa forma, este grupo teve o valor total de produção de R \$ 2,53 milhões no ano de 2016, em oito estados do país. Segundo a FAO, a ranicultura brasileira chegou a $600 \mathrm{t}$ anuais no período de 2008 a 2012; entretanto, apresentou um declínio nos últimos anos atingindo o valor de apenas 300 t no ano de 2016 (FAO, 2018; IBGE, 2016).

Os desafios para continuar aumentando a produção na aquicultura dependem de uma série de melhorias incluindo práticas de manejo, rações de qualidade, melhoramento genético e sanitário. Uma vez que, como outros sistemas de produção animal, a aquicultura enfrenta problemas com doenças resultantes de sua intensificação e comercialização. Os aspectos sanitários da produção e a falta de estrutura para o diagnóstico das principais enfermidades infecciosas são considerados de grande relevância e entreves para o crescimento (FAO, 2015; FIGUEIREDO; LEAL, 2008).

$\mathrm{Na}$ piscicultura alguns dos agentes etiológicos que mais causam danos são: as bacterioses, sendo os agentes principais: Aeromonasspp., Streptococcus spp., Vibrio spp. e Lactococcus spp; parasitoses: com destaque para Ichthyophthirius multifiliis e Gyrodactylus salaries; fungos: Aphanomyces invadans e Saprolegnia diclina; e principalmente as viroses causadas por vírus das famílias Iridoviridae, Rhabdoviridae; Orthomyxoviridae, Alloherpesviridae e Nodaviridae (FIGUEIREDO; LEAL, 2008; 
MACHIMBIRIKE et al., 2019; OIE, 2019; WALKER; WINTER, 2010; ZHANG; GUI, 2015).

Os patógenos que mais afetam os anfíbios em ranários são de origem: fúngica, a quitridiomicose provocada por Batrachochytridium desdrobatidis, fungos do gênero Saprolegnia, Aspergillus sp. Fusarium sp., Candida sp.; virais: ranaviroses provocadas por membros do gênero Ranavirus, vírus dos grupos herpes, toga e paramixo; bacteriana: as denominadas "red-leg" causadas pelos agentes Staphylococcus aureus, Aeromonas hydrophila, Pseudomonas aeruginosa e Citrobacter freundii, as micobacterioses por Mycobacterium spp., e Streptococcus spp.; as parasitoses: Longibucca catesbeianae, Lernaea cyprinacea, Cryptosporidium e Giardia spp. (HIPOLITO, 2004; OIE, 2019; PEREIRA et al., 2015).

Portanto, são oportunas as pesquisas que visam identificar e tratar as doenças que afetam os peixes e anfíbios em ambientes de cultivo, visto que, os patógenos virais são considerados uma das causas de perdas econômicas na aquicultura mundial, devido ao fato de serem de difícil prevenção e controle, além da inexistência de tratamentos efetivos contra essas infecções (CRANE; HYATT, 2011; OIE, 2015).

\subsection{Família Iridoviridae}

A família Iridoviridae compreende vírus de dsDNA, classificados como vírus núcleo-citoplasmáticos grandes de DNA, com genoma de 105-212 kpb. Capsídeos icosaédricos que variam em tamanho de 120 a $200 \mathrm{~nm}$ de diâmetro, fazendo com que no citoplasma das células infectadas sejam identificados sítios de montagem viral, onde os vírions são facilmente observados dentro de matrizes paracristalinas ou brotamento da membrana plasmática (CHINCHAR; YU; JANCOVICH, 2011; CHINCHAR et al., 2017). Tem sido proposto que a família seja agrupada com outras famílias (Poxviridae, Ascoviridae, Asfarviridae, Phycodnaviridae, Mimiviridae e Marseilleviridae) em uma linhagem monofilética, classificadas dentro de uma nova ordem taxonômica denominada Megavirales (CHINCHAR; WALTZEK; SUBRAMANIAM, 2017).

Subdividida em Alphairidovirinae e Betairidovirinae, a família Iridoviridae apresenta cinco gêneros: Iridovirus, Chloriridovirus, Ranavirus, Lymphocystivirus e Megalocytivirus (WHITTINGTON; BECKER; DENNIS, 2010). A subfamília Betairidovirinae compreende os gêneros Iridovirus e Chloriridovirus, que infectam 
invertebrados, primeiramente insetos, mas também crustáceos e moluscos, sendo registradas mais de 100 espécies infectadas. As infecções desta subfamília envolvem níveis maciços de replicação viral que resultam iridescêncianas larvas infectadas, dando a origem ao nome da família iridovírus, poisÍris na mitologia grega é a personificação do arco-íris. Estes gêneros foram previamente distinguidos com base no tamanho do vírion e na cor iridescente dos artrópodes infectados (CHINCHAR et al., 2005; WILLIAMS; BARBOSA-SOLOMIEU; CHINCHAR, 2005; CHINCHAR et al., 2017).

A subfamília Alphairidovirinae compreende os demais gêneros da família: Ranavirus, Lymphocystivirus e Megalocytivirus, que causam infecções em vertebrados ectotérmicos. Os gêneros Lymphocystivirus e Megalocytivirus infectam apenas peixes e o gênero Ranavirus contêm espécies que infectam anfíbios, répteis e peixes (Osteichthyes) (CHINCHAR et al. 2005; CHINCHAR; YU; JANCOVICH, 2011), sendo, Ranavirus e Megalocytivirus notoriamente reconhecidos por causar alta mortalidade em muitas espécies de interesse econômico (LIU et al., 2015).

Alguns autores têm proposto a criação de um novo gênero para a família Iridoviridae, para acomodar os iridovírus eritrocíticos, Viral erythrocytic necrosis (VEN), como o Erythrocytic necrosis virus (ENV), um agente patogênico responsável por causar doenças em peixes marinhos e anádromos, caracterizado pela presença de corpos de inclusão citoplasmáticos nos eritrócitos, anemia, aumento da suscetibilidade a infecções secundárias e mortalidade direta. Análises filogenéticas indicam que o ENV agrupa com outros iridovírus eritrocíticos de cobra (Thamnophis sauritus erythrocytic virus) e de lagarto (Lacerta monticola erythrocytic virus) (DE MATOS et al., 2011; EMMENEGGER et al., 2014; PURCELL et al., 2016). Entretanto, mais estudos são necessários para o reconheimento pelo Comitê Internacional de Taxonomia de Vírus (International Committee on Taxonomy of Viruses - ICTV).

As consequências biológicas resultantes das infecções por iridovírus variam de acordo com o tipo do vírus e do hospedeiro, portanto, apresentam variadas manifestações clínicas e os animais infectados podem ser sintomáticos, assintomáticos ou com morte rápida (JANCOVICH et al., 2005; LANGDON et al., 1986). Destacando a subfamíla Alphairidovirinae, os Lymphocystivirus infectam mais de 100 espécies de peixes marinhos e de água doce, encontram-se distribuídos mundialmente e são representados pelo vírus Lymphocystis disease virus (LCDV), classificado em duas linhagens: uma européia/Oceano Atlântico (LCDV-1) e uma asiática/Oceano Pacífico 
(LCDV-C) (WILLIAMS; BARBOSA-SOLOMIEU; CHINCHAR,2005). A infecção por linfocistivírus leva a crescimentos semelhantes à verrugas ou tumores, compostos por aglomerados de células infectadas individuais (de $1 \mathrm{~mm}$ de diâmetro) principalmente na superfície externa da pele dos peixes, que se rompem liberando as partículas virais na água; em alguns casos, estas lesõem podem atingir os órgãos internos (ALONSO et al., 2005; CHINCHAR; WALTZEK; SUBRAMANIAM, 2017). As verugas regridem espontaneamente e, a menos que afetem a alimentação ou o movimento, não contribuem para altos níveis de mortalidade; entretanto, geram perdas econômicas por afetar a aparência do animal (ALONSO et al., 2005; LIU et al., 2015). No Brasil, recentemente foi realizada a primeira identificação de sequências genômicas de Lymphocystivirus em peixes ornamentais, da espécie peixe-anjo-imperador (Pomacanthus imperator) (MAGANHA et al., 2019, no prelo).

Os membros do gênero Megalocytivirus infectam mais de 50 espécies de peixes de água doce e marinhos. São patógenos emergentes, identificados na década de 90, sendo que as infecções causam doença sistêmica envolvendo múltiplos órgãos internos e têm potencial para causar mortalidade de quase $100 \%$ nos peixes infectados (KURITA; NAKAJIMA, 2012; WHITTINGTON; BECKER; DENNIS, 2010). Visto que têm sido responsáveis pordeclíniosprincipalmente na maricultura da Ásia, os patógenos do gênero estão distribuidos mundialmente (WHITTINGTON; BECKER; DENNIS, 2010). Atualmente, são reconhecidas quatro espécies: Red sea bream iridovirus (RSIV), Infectious spleen and kidney necrosis virus (ISKNV), Turbot reddish body iridovirus (TRBIV) e Threespine stickleback iridovirus (TSIV); além disso, vários isolados tem sido descritos (ZHANG; GUI, 2015). Os sinais clínicos apresentados pelos animais infectados são:anorexia, letargia, exoftalmia, lesões na superfície da pele, anemia, natação irregular, fezes esbranquiçadas e presença de lesões hemorrágicas nos órgãos internos, bem como, aumento de tamanho do fígao e baço. Na avaliação histológica, as infecções são caracterizadas pela presença de células com corpos de inclusão. O Brasil, já registra a ocorrência de Megalocytivirus, possivelmente devido ao forte comércio internacional de peixes ornamentais, pois foram detectados em Pygocentrus nattereri, piranhas vermelhas comercializadas como peixe ornamental (alimentadas com outro peixe ornamental, o lebiste, Poecilia reticulata, uma vez que a sequencia genômica revelou alta similaridade com uma cepa da Malásia (CARDOSO et al., 2017; MAGANHA et al., 2018). 
O primeiro vírus do gênero Ranavirus foi isolado de anfíbios com carcinomas renais, sendo o agente responsável pelo tumor de Lucke denominado de Frog virus 3 (FV3) (GRANOFF; CAME; BREEZE, 1966). Atualmente, sabe-se que as ranaviroses causam infecções sistêmicas e estão presentes em todos os continentes (com exceção da Antártida). Foram relatadas ao menos 175 espécies em 53 famílias de vertebrados ectotérmicos infectados por ranavírus (DUFFUS et al., 2015) (Figura 1). Entretanto, não está claro se a distribuição global é um reflexo de sua maior virulência e capacidade de disseminação (por meio de atividades naturais ou humanas), ou pela maior vigilância associada a melhores mecanismos de diagnóstico e detecção aplicados nas últimas décadas (GRAY; CHINCHAR, 2015). Independentemente das razões, os ranavírus agora são vistos como agentes patogênicos emergentes, responsáveis por uma série de epizootias e perdas econômicas na produção aquícola mundial, inclusive no Brasil (MAZZONI et al., 2009). Perante esta maior atenção sobretudo pelo aumento dos relatos de morbidade e mortalidade de anfíbios, répteis e peixes em decorrência de infecções por esses agentes, foi criado o Global Ranavirus Consortium (GRC Consórcio Global de Ranavírus), para facilitar a comunicação e colaboraçãodos grupos de pesquisa pelo mundo, compartilhando informações, registando e atualizando a ocorrência de ranaviroses, promovendo simpósios, cursos, treinamentos e discussões sobre o assunto (GRC, 2019).

Figura 1 - Mapa da distribuição global de casos de Ranavirus

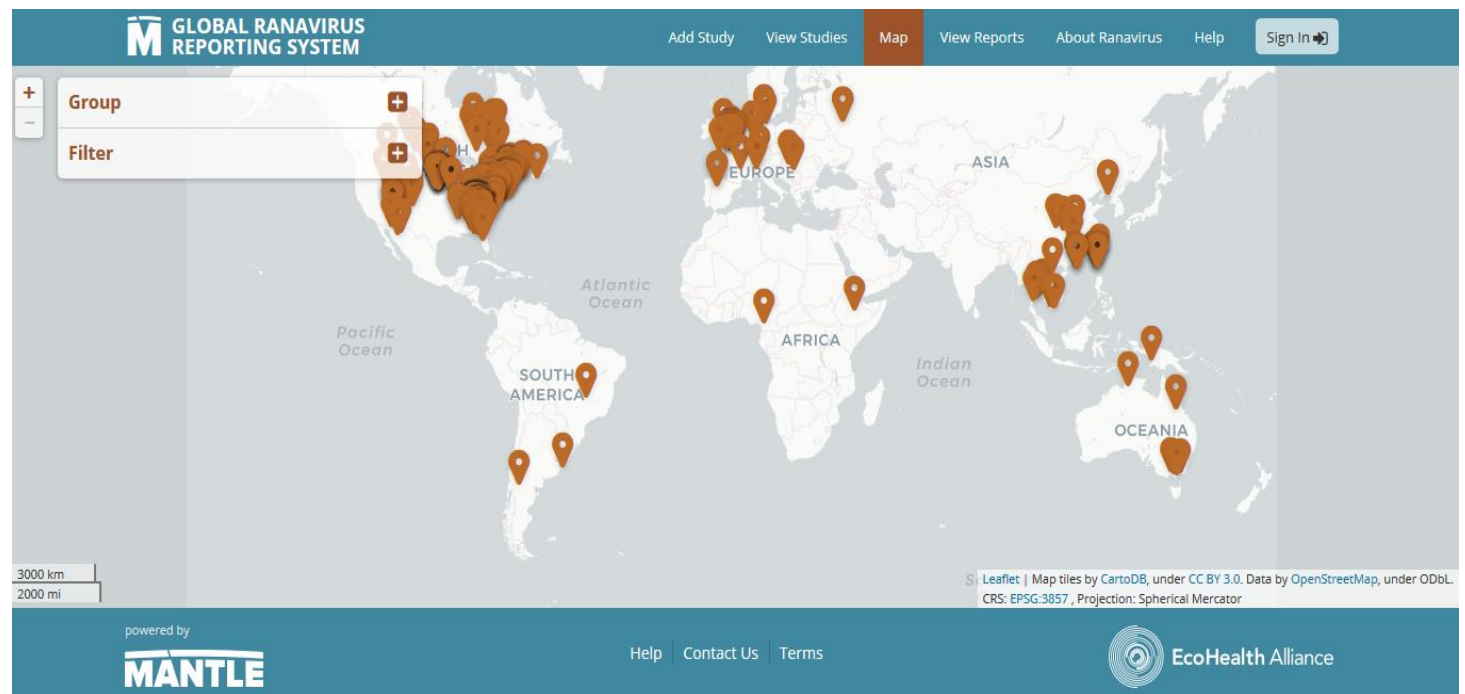

Legenda: Ícone de localização determinando os registos de Ranavirus no mundo. Nota: na Venezuela também foi reportado a ocorrência de Ranavirus (ZUPANOVIC et al., 1998). Fonte: Global Ranavirus Reporting System (GRRS): https://mantle.io/grrs/map. Acesso em: 21/08/2019. 


\subsection{Ranavirus}

O gênero Ranavirus, responsável por doenças sistêmicas em peixes, anfíbios e répteis (LESBARRÈRES et al., 2012; WHITTINGTON; BECKER; DENNIS, 2010), possui oito espécies reconhecidas: Ambystoma tigrinum virus (ATV); Bohle iridovirus (BIV); Common midwife toad virus (CMTV); European catfish virus (ECV); Epizootic haematopoietic necrosis virus (EHNV); Frog virus 3 (FV3); Santee-Cooper ranavirus (SCRV) e Singapore grouper iridovirus (SGIV) (CHINCHAR et al., 2017).

Dentro de cada espécie existem cepas e isolados já identificados, uma vez que, geralmente, recebem o nome do hospedeiro do qual foram isolados, mas ainda não foram aprovados ao patamar de espécie ICTV (JANCOVICH et al., 2012; JANCOVICH et al., 2015) (Tabela 2). Constantemente, o ICTV concentra-se no desenvolvimento de critérios para caracterizar taxonomicamente os membros da família em nível de gênero e espécie; assim, pode ser necessário revisar o número de espécies de Ranavius, pois se a identidade entre sequências genômicas for maior de $90 \%$, dois vírus serão membros da mesma espécie. Então FV3, juntamente com várias espécies atualmente reconhecidas, como BIV, EHNV e ATV, poderiam ser considerados linhagens da mesma espécie (CHINCHAR; WALTZEK; SUBRAMANIAM, 2017).

A espécie FV3 é o membro melhor caracterizado dentro do gênero Ranavirus, é considerada a espécie modelo da família Iridoviridae, denominada Espécie Tipo (CHINCHAR et al., 2009; MAJJI et al., 2009; WILLIANS; BARBOSASOLOMIEU; CHINCHAR, 2005). É da espécie tipo que vem a maioria das informações sobre os Ranavirus, como estrutura, replicação viral, interação vírushospedeiro, transcrição viral entre outros estudos. 
Tabela 2 - Espécies e isolados/cepas de Ranavirus

\begin{tabular}{|c|c|c|c|}
\hline Espécie & Hospedeiro & Continente & GenBank \\
\hline ATV (Ambystoma tigrinum virus) & Salamandra & A. do Norte & AY150217 \\
\hline BIV (Bohle iridovirus) & rã & Oceania & AY187046 \\
\hline CMTV (Common midwife toad ranavirus) & sapo & Europa & JQ231222 \\
\hline EHNV (Epizootic haematopoietic necrosis virus) & peixe & Oceania & FJ433873 \\
\hline ECV (European catfish virus) & peixe & Europa & KT989884 \\
\hline FV3 (Frog virus 3 ) & rã & A. do Norte & AY548484 \\
\hline SGIV (Singapore grouper iridovirus) & peixe & Ásia & AY521625 \\
\hline SCRV (Santee-Cooper ranavirus) & peixe & Ásia & KU507317 \\
\hline \multicolumn{4}{|l|}{ Isolado/cepa } \\
\hline ADRV (Andrias davidianus ranavirus) & Salamandra gigante & Ásia & KC865735 \\
\hline ADRV-2 & Salamandra gigante & Ásia & KF033124 \\
\hline CGSIV (Chinese giant salamander iridovirus) & Salamandra gigante & Ásia & KF512820 \\
\hline CoIV (Cod iridovirus) & peixe & Europa & KX574342 \\
\hline ESV (European sheatfish virus) & peixe & Europa & JQ724856 \\
\hline Frog virus $3(\mathrm{FV} 3)$ & rã & Europa & MF360246 \\
\hline Frog virus 3 (FV3) & peixe & A. do Norte & KF646249 \\
\hline Frog virus 3 isolate SSME (FV3_SSME) & desconhecido & A. do Norte & KJ175144 \\
\hline FV3-símile & rã & A. do Sul & MH351268 \\
\hline GGRV (German gecko ranavirus) & lagarto & Europa & KP266742 \\
\hline GIV (Grouper iridovirus) & peixe & Ásia & AV666015 \\
\hline GV6 (Guppy virus 6) & peixe & Europa & FR677325 \\
\hline Pike-perch iridovirus (PPIV) & peixe & Europa & KX574341 \\
\hline RCV-Z (Rana catesbeiana virus) & rã & A. do Norte & MF187210 \\
\hline REIR (Rana esculenta virus) & rã & Europa & FJ515796 \\
\hline RGV (Rana grylio virus) & rã & Ásia & JQ654586 \\
\hline Rmax (Ranavirus maximus) & peixe & Europa & KX574343 \\
\hline SERV (Short-finned eel ranavirus) & peixe & Oceania & KX353311 \\
\hline SSME (Spotted salamander Maine) & salamandra & A. do Norte & KJ175144 \\
\hline STIV (Soft-shelled turtle iridovirus) & tartaruga & Ásia & EU627010 \\
\hline TFV (Tiger frog virus) & rã & Ásia & AF389451 \\
\hline THI (Testudo hermanni isolate) & tartaruga & Europa & KP266741 \\
\hline ToRV1 (Tortoise Ranavirus isolate 1) & tartaruga & Europa & KP266743 \\
\hline
\end{tabular}

Legenda: Lista de alguns isolados/cepas de apenas ranavírus com genoma completo depositado no GenBank.Fonte: Própria autoria.

Os ranavírus são vírus icosaédricos $(T=133$ ou 147), as partículas infecciosas podem ser envelopadas alcançando entre 160-200nm de diâmetro ou não envelopadas (nus) com cerca de 150nm; sendo os vírionsnão envelopados liberados por lise celular, enquanto há vírions que brotam da membrana plasmática e, no processo, adquirem um envelope que aumenta a infecciosidade específica (Figura 2). Possuem uma única molécula de DNA fita dupla linear de 104-140kpb, com 49-57\% de G+C e DNA altamente metilado (CHINCHAR et al., 2005; CHINCHAR et al., 2017; 
CHINCHAR; WALTZEK; SUBRAMANIAM, 2017; ROBERT; CHINCHAR, 2012). Acredita-se que a metilação do DNA seja uma forma de proteção, para prevenir o reconhecimento via Toll-like do hospedeiro e proteger da ação de endonuclease produzida pelo próprio vírus (CHINCHAR; WALTZEK; SUBRAMANIAM, 2017).

Figura 2- Esquematização da estrutura do vírion

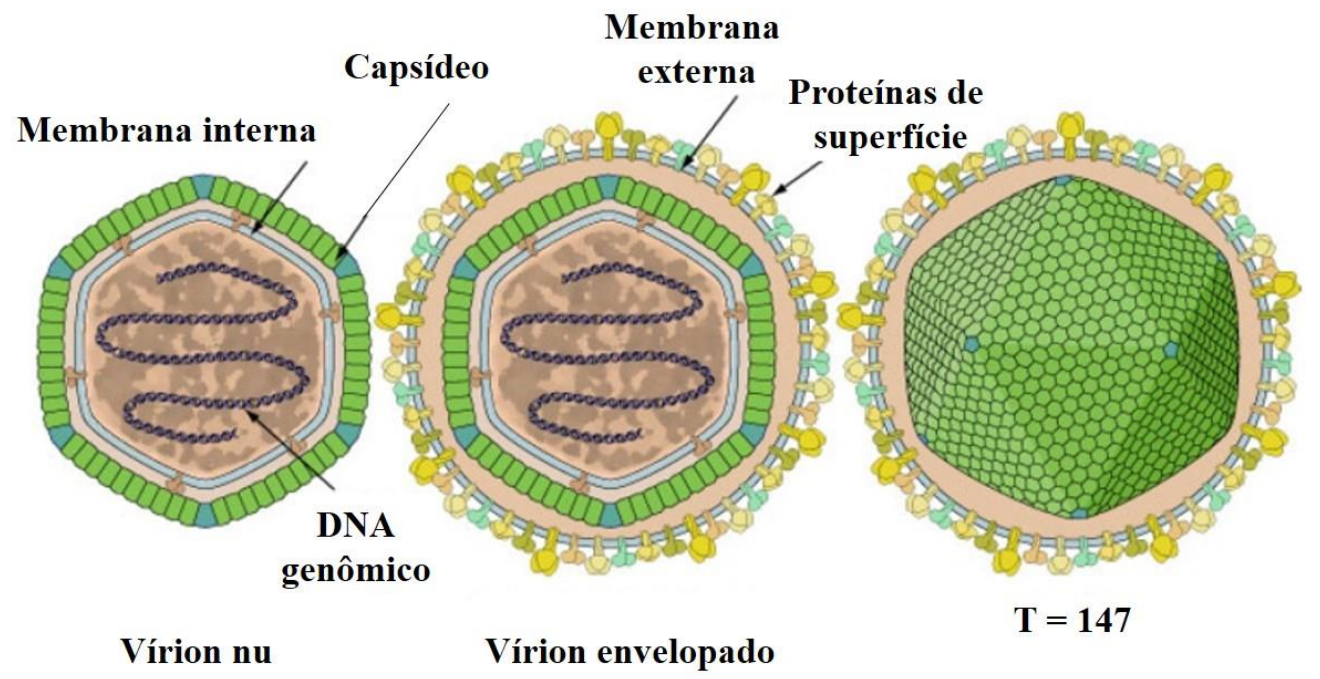

Fonte: Adaptado de ViralZone, Swiss Institute of Bioinformatics, 2009. Disponível em: https://viralzone.expasy.org/581?outline=all_by_species. Acesso em: 11/09/2017.

Ranavírus como o FV3 são geneticamente e sorologicamente distintos dos membros de outros gêneros da família Iridorividae; entretanto, vários ranavírus isolados de peixes, anfíbios e répteis apresentam parentesco genético e/ou sorológico com o FV3 (CHINCHAR et al., 2005). Até o presente momento, cerca de 30 ranavírus tiveram seus genomas completos depositados nos bancos de sequências, sendo neles observadas proteínas homólogas aos demais vírus da família Iridoviridae. Os ranavírus possuem 72 genes conservados, sendo que, em sua maior parte, vírus do mesmo clado apresentam uma colinearidade na ordem dos genes, podendo apresentar algumas inversões em blocos de genes ou ainda presença ou ausência de um ou mais genes (indels) (CHINCHAR; WALTZEK; SUBRAMANIAM, 2017).

Os 26 genes de Ranavirus comuns a outros membros da família, Iridoviridae, mostram relação com produtos gênicos previamente caracterizados (Tabela 3). Entretanto, 27 genes são encontrados apenas em Ranavirus e 13 em ranavírus anfíbios-like que não se identificam com genes putativos fora deste gênero, sugerindo 
que estes possam desempenhar papéis específicos que afetam a interação vírushospedeiro. Dos 27 genes específicos para ranavírus, apenas três têm função conhecida; codificam uma proteína contendo CARD (64R), dUTPase (63R) e proteína semelhante a $\mathrm{H} 1$ do tripleto neurofilamento (32R), enquanto 24 genes permanecem com a função desconhecida. Do mesmo modo, apenas dois dos 13 genes de ranavírus anfíbios-like (26R, vIF-2 $\alpha$; 82R, proteína imediata inicial de $18 \mathrm{kDa}$ ) têm homólogos putativos (CHINCHAR et al., 2017; EATON et al., 2007, JANCOVICH et al., 2010; JANCOVICH et al., 2012; ZHANG; GUI, 2015).

Tabela 3 - Principais genes da família Iridoviridae. As designações das ORFs são baseadas em suas posições dentro do genoma do FV3 (AY548484)

\begin{tabular}{|c|c|c|c|c|c|}
\hline ORF & Função putativa & Categoria $^{a}$ & ORF & Função putativa & Categoria $^{a}$ \\
\hline 1R & $\begin{array}{l}\text { Fator de replicação putativa } \\
\text { e/ou ligação ao DNA / } \\
\text { proteína de empacotamento }\end{array}$ & $\mathrm{C}$ & $57 R$ & $\begin{array}{l}\text { Serina / treonina proteína } \\
\text { quinase }\end{array}$ & $\mathrm{C}$ \\
\hline $2 \mathbf{L}$ & $\begin{array}{l}\text { Proteína de membrana } \\
\text { miristilada }\end{array}$ & $\mathrm{S}$ & $60 \mathrm{R}$ & $\begin{array}{l}\text { Exonuclease da família } \mathrm{B} \text { da } \\
\text { DNA polimerase }\end{array}$ & $\mathrm{C}$ \\
\hline $\mathbf{8 R}$ & $\begin{array}{l}\text { DNA Dependente, RNA } \\
\text { polimerase II, subunidade } \alpha\end{array}$ & $\mathrm{C}$ & $62 \mathrm{~L}$ & $\begin{array}{l}\text { DNA Dependente, RNA } \\
\text { polimerase II, subunidade } \beta\end{array}$ & $\mathrm{C}$ \\
\hline 9L & NTPase/ helicase & $\mathrm{C}$ & $67 \mathrm{~L}$ & $\begin{array}{l}\text { Ribonucleotídeo redutase, } \\
\text { subunidade pequena }(\operatorname{RR} \alpha)\end{array}$ & $\mathrm{C}, \mathrm{V}$ \\
\hline $12 \mathrm{~L}$ & $\begin{array}{l}\text { Função desconhecida } \\
\text { AAA-ATPase semelhante }\end{array}$ & UNK & $80 \mathrm{~L}$ & RNase III & $\mathrm{C}, \mathrm{V}$ \\
\hline $15 R$ & $\begin{array}{l}\text { AAA-AIPase, semeInante } \\
\text { ao poxvírus A32, necessário } \\
\text { para empacotamento de } \\
\text { DNA }\end{array}$ & $\mathrm{C}$ & $81 R$ & $\begin{array}{l}\text { Fator de alongamento } \\
\text { transcrição TFIIS }\end{array}$ & $\mathrm{C}$ \\
\hline 19R & $\begin{array}{l}\text { Serina / treonina proteína } \\
\text { quinase }\end{array}$ & $\mathrm{C}$ & 84R & $\begin{array}{l}\text { Antígeno nuclear de } \\
\text { proliferação celular (PCNA) }\end{array}$ & $\mathrm{C}$ \\
\hline $21 \mathrm{~L}$ & Proteína da família helicase & $\mathrm{C}$ & $85 R$ & Deoxinucleósido quinase & $\mathrm{C}$ \\
\hline 22R & $\begin{array}{l}\text { NTPase da família D5 } \\
\text { envolvida na replicação do } \\
\text { DNA }\end{array}$ & $\mathrm{C}$ & 88R & $\begin{array}{l}\text { Erv/Alr família } \\
\text { oxidorredutases tiol }\end{array}$ & $\mathrm{C}, \mathrm{V}$ \\
\hline 27R & $\begin{array}{l}\text { Tirosina quinase putativa / } \\
\text { Enzima modificandora LPS }\end{array}$ & $\mathrm{C}, \mathrm{V}$ & 90R & $\begin{array}{l}\text { Proteína principal } \\
\text { capsídeo (MCP) }\end{array}$ & $\mathrm{S}$ \\
\hline 37R & NIF-NLI fator de interação & V & 91R & $\begin{array}{l}\text { Proteína precoce imediata } \\
\text { ICP-46 }\end{array}$ & UNK \\
\hline 41R & $\begin{array}{l}\text { Fator de transcrição precoce } \\
\text { do vírus vaccinia }\end{array}$ & $\mathrm{C}$ & 94L & Uvr/REP helicase & $\mathrm{C}$ \\
\hline 53R & $\begin{array}{l}\text { Proteína de membrana } \\
\text { miristilada }\end{array}$ & $\mathrm{S}$ & 95R & Putativa RAD2-type nuclease & $\mathrm{C}$ \\
\hline
\end{tabular}

Legenda: ${ }^{2}$ letras da categoria refletem a função conhecida ou putativa das proteínas indicadas: C - catalítico; S - estrutural, V - virulência e UNK - desconhecido. Destaque à ORF90R, posição do gene MCP. Fonte: Adaptado de ICTV Report, 2018. Disponível em: https://talk.ictvonline.org/ictv-reports/ictv_online_report/dsdna-viruses/w/iridoviridae. Acesso em: 26 jul. 2019. 
O gene melhor estudado na família Iridoviridae e, portanto, em Ranavirus, é o gene MCP (major capsid protein), constituído de 1392 pb, codificando a proteína principal do capsídeo, uma proteína estrutural de $50 \mathrm{kDa}$ (463 aminoácidos), que compreende cerca de $40-45 \%$ da proteína total do vírus, sendo que dentre as espéciesdo gênero à similaridade da sequência do gene MCP é superior a 70\% (CHINCHAR et al., 2017; HUANG et al., 2011; JANCOVICH et al., 2012). Devido a conservação do gene, as sequências de MCP são usadas para identificação e caracterização viral, bem como estudos de evolução e fillogenia de ranavírus (HYATT et al., 2000; MAO; HEDRICK; CHINCHAR, 1997; MARSH et al., 2002). Uma vez que as proteínas estruturais virais podem servir como um antígeno capaz de estimular a resposta imune contra infecções virais, investigações sobre o papel da proteína $\mathrm{MCP}$ nos processos patológicos de infecções por iridovírus também têm sido realizadas, bem como, possível utilização como vacinas (LIU et al., 2015; MAHARDIKA et al., 2016; ZHOU et al., 2015).

A replicação viral dos ranavírus foi descrita baseda na replicação do FV3, ela ocorre no núcleo e no citoplasma da célula hospedeira, utilizando ambas enzimas, hospedeiras e virais. A entrada do vírion na célula hospedeira ocorre de duas formas, dependendo da ausência ou presença do envelope no vírion; no primeiro caso, os vírus nus (sem envelope) entram na célula por fusão com a membrana plasmática, já os vírus envelopados entram na célula pelo processo de endocitose, isto é, por uma ligação a um receptor da membrana plasmática, dependente de $\mathrm{pH}$ e clatrina (CHINCHAR; YU; JANCOVICH, 2011). Recentemente, foi proposta a entrada via pinocitose ou por mecanismos mediados por caveolina (WANG et al., 2014).

Após a entrada na célula, o capsídeo é desmontado e o genoma viral liberado é transportado até ao núcleo onde irá ocorrer a primeira etapa do processo replicativo (CHINCHAR; WALTZEK; SUBRAMANIAM, 2017). Os genes virais são expressos em uma cascata temporal ordenada, consistindo em genes imediatos precoces (IE - imediate early), precoces tardios (DE - delayed early ) e tardios ( $\mathrm{L}$ - late) (MAJJI et al., 2009). Os primeiros transcritos virais IE e DE têm como molde o DNA do vírion, sendo os transcritos iniciais traduzidos em proteínas reguladoras e nas principais enzimas, tais como a DNA polimerase e a RNA polimerase, que é homóloga a RNA polimerase tipo II do hospedeiro. Esta primeira etapa de transcrição IE é catalisada pela RNA polimerase II do hospedeiro. Na segunda etapa, o DNA sintetizado no núcleo é transportado para o citoplasma, em seguida ocorre uma nova síntese de DNA, formando 
estruturas compostas de 10 ou mais moléculas de DNA viral (concatâmeros); é neste momento que ocorre a metilação do DNA viral por uma metiltransferase codificada pelos ranavírus, uma forma de proteção do DNA (GOORHA et al., 1984). Na transcrição viral tardia, provavelmente no citoplasma, são transcritos e traduzidos as proteínas estruturais para a formação dos vírus descendentes (CHINCHAR; WALTZEK; SUBRAMANIAM, 2017).

$\mathrm{Na}$ última fase, ocorre a montagem dos recém-sintetizados vírions, onde as proteínas estruturais virais e o DNA são empacotados nos locais de morfogênese viral (CHINCHAR; WALTZEK, 2014). Os vírions recém-formados se acumulam no citoplasma, formando arranjos paracristalinos característicos dos iridovírus. Estes saem da célula por brotamento, através do qual adquirem o envelope derivado da membrana plasmática do hospedeiro, ou por lise celular (CHINCHAR; WALTZEK; SUBRAMANIAM, 2017).

A infecção pelo FV3 resulta em uma rápida inibição da síntese de proteínas e RNA da célula hospedeira, além da inibição da síntese macromolecular da célula hospedeira. Na replicação viral in vitro podem ser observadas alterações celulares, denominadas de forma geral, efeito citopático (ECP), onde ocorre formação de grandes inclusões citoplasmáticas facilmente detectáveis por microscopia óptica, acompanhado pelo arredondamento das células, e ainda, pode também ser acompanhada pela emissão de pseudópodes alongados onde se processa o brotamento das partículas virais. Os Ranavirus demonstram induzir morte celular por apoptose, através de alterações características como condensação da cromatina e fragmentação do DNA do hospedeiro (CHINCHAR et al., 2003; CHINCHAR; WALTZEK; SUBRAMANIAM, 2017).

A temperatura ótima de replicação varia de 26 a $30{ }^{\circ} \mathrm{C}$, com a replicação inibida a temperaturas superiores a $32^{\circ} \mathrm{C}$, restringindo a replicação in vivo a outros hospedeiros não ectotérmicos. Experimentos in vitro demostram que a replicação do FV3 é lenta ou inexistente em temperaturas menores de $12{ }^{\circ} \mathrm{C}$; já a replicação em temperaturas mais elevadas, $28{ }^{\circ} \mathrm{C}$ a $32{ }^{\circ} \mathrm{C}$, é maior, isso explicaria a relação dos surtos ocorrerem mais no verão, já que foi verificado, por exemplo, que em anfíbios a suscetibilidade é afetada pela elevação da temperatura da água (BRAND et al., 2016; CHINCHAR et al., 2002). 
Figura3 - Ciclo da replicação viral dos Ranavirus

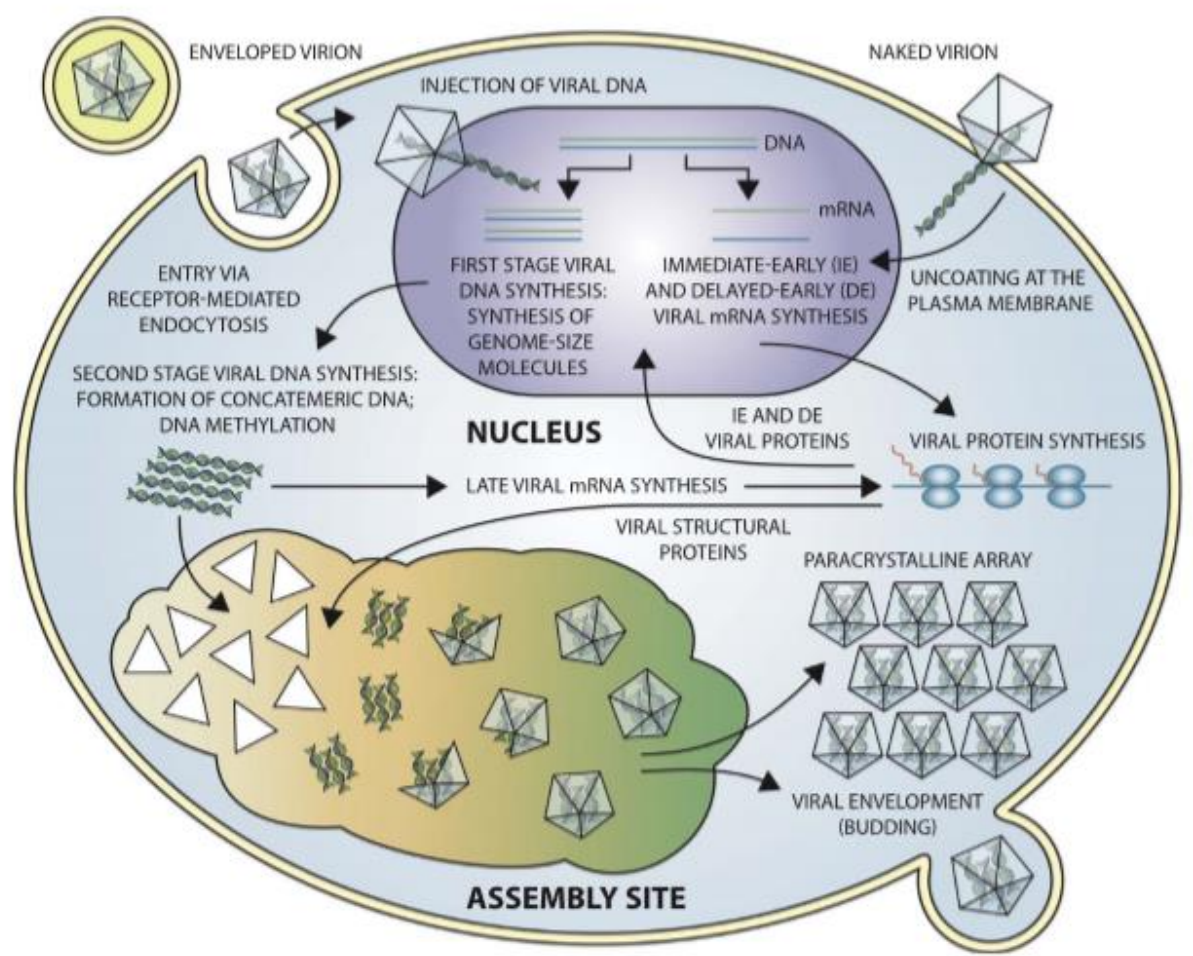

Legenda: O DNA viral entra no núcleo onde ocorrem a transcrição viral precoce e a síntese do genoma de DNA. Posteriormente, o genoma é transportado para o citoplasma, onde são metilados e ocorre a síntese de DNA no segundo estágio resultando na formação de concatâmeros compostos por 10 ou mais moléculas de DNA. A transcrição tardia requer síntese viral contínua de DNA e é catalisada por uma RNA polimerase dependente de DNA codificada pelo vírus. O DNA e as proteínas virais interagem em locais de montagem viral; após a sua formação os vírions maduros podem ser encontrados no citoplasma em arranjos paracristalinos, deixando a célula por brotamento ou lise. Fonte: CHINCHAR, V.G.; WALTZEK, T.B.; SUBRAMANIAM, K. Ranaviruses and other members of the family Iridoviridae: Their place in the virosphere.Virology, Waltham, v. 511, p. 259-271. Nov. 2017.

Algumas espécies de ranavírus podem infectar não apenas várias espécies hospedeiras dentro de uma classe taxonômica, mas também membros de diferentes classesde vertebrados ectotérmicos (peixes ósseos, anfíbios e répteis). Por isso, os ranavírus são considerados patógenos emergentes e promíscuos (CHINCHAR et al., 2017; CHINCHAR; WALTZEK; SUBRAMANIAM, 2017). Por exemplo, a infecção por EHNV já foi relatada em pelo menos 13 espécies de peixes; FV3 e BIV são capazes de infectar hospedeiros das três classes; e mais, devido a sua distribuição global, podem ocorrer a coexistência de espécies/cepas na mesma região. Em tempo, infecções 
experimentais em anfíbios (Rana aurora) com ATV e FV3 demostram que na coexposição há o dobro de indivíduos infectados, sendo que a coinfecção aumenta a infectividade e a replicação viral (CHINCHAR et al., 2017; CHINCHAR; WALTZEK; SUBRAMANIAM, 2017; DUFFUS et al., 2015; MIHALJEVIC; HOVERMAN; JOHNSON, 2018).

Estudos relatam que Ranavirus infectam pelo menos 22 famílias de peixes (DUFFUS et al., 2015), e membros do gênero já foram identificados em mais de 40 espécies selvagens e cativas na Oceania, Ásia, Europa e Américas (AHNE et al., 1997; ALMEIDA-QUEIROZ et al., 2014; BORZYM; KARPINSKA; REICHERT, 2015; LANGDON et al., 1986; PENG et al., 2015; PLUMB et al., 1996;).

Em anfíbios, diversas infecções por ranaviroses já foram identificadas em animais selvagens e cultivados na Ásia, Américas, Oceania, África e Europa, sendo um dos responsáveis principais pelo declínio mundial dos anuros na natureza (ALENCAR, 2016; CULLEN; OWENS, 2002; CUNNINGHAM et al., 1996; DOCHERTY-BONE et al., 2013; DUFFUS et al., 2017; FOX et al., 2006; GALLI et al., 2006; MAZZONI et al., 2009; OLIVEIRA, 2020; WOLF et al., 1968; ZHANG et al., 2001; ZUPANOVIC et al., 1998). Em salamandras, ocorrências foram registadas na América do Norte e Ásia (BOLLINGER et al., 1999; DOCHERTY et al., 2003; ZHOU et al. 2013); e em répteis na Europa, América do Norte, Ásia e Austrália (CHEN; ZHENG; JIANG, 1999; DE VOE et al., 2004; HYATT et al., 2002, HUANG et al., 2009; MARSCHANG et al., 1999; WINZELER et al., 2015). Sendo assim, fica evidente sua extensa distribuição global e sua capacidade de causar doenças em várias espécies de vertebrados ectotérmicos (CHINCHAR et al., 2017; DUFFUS et al., 2015).

Avaliando a história evolutiva dos Ranavirus com base em seus hospedeiros, originalmente estes vírus eram restritos aos peixes; ao longo do processo evolutivo, por eventos de mutações, deleções, inserções, aquisições de novos genes, ou seja, alterações genéticas, seguidas da exposição a novos hospedeiros; os ranavírus sofreram essa radiação na diversidade dentro do gênero e nos hospedeiros infectados (ABRANS et al., 2013; CHINCHAR; YU; JANCOVICH, 2011; PRICE et al., 2017). Em suma, primeiro ocorrem as infecções raras, depois transmissões locais, transmissões interespecíficas ou interclasses e, por fim, as epidemias. Genes envolvidos na interação hospedeiro-patógeno exibem seleção positiva durante o estabelecimento de novas espécies virais (ABRANS et al., 2013). 
Filogeneticamente os Ranavirus são divididos em três clados: FV3-like que agrupa os vírus que infectam comumente anfíbios; CMTV-like que agrupam principalmente os vírus que infectam répteis eo clado mais antigo, ATV-likeou EHNVlike (denominação preferida por alguns autores), onde estão os vírus que infectam peixes (Figura 4). Acredita-se que esta evolução adaptativa de hospedeiros seguiu dos peixes, caudatas (salamandras), anuros e, por fim, chegando aos répteis (squamatas e quelônios) (CLAYTOR et al., 2017; PRICE et al., 2017). Sendo o FV3, portanto, o mais recente dos Ranavirus e que traz essa capacidade de infectar as três classes de vertebrados ectotérmicos (CHINCHAR; YU; JANCOVICH, 2011).

Figura 4 - Filogenia dos Ranavirus com base na evolução dos hospedeiros do gênero

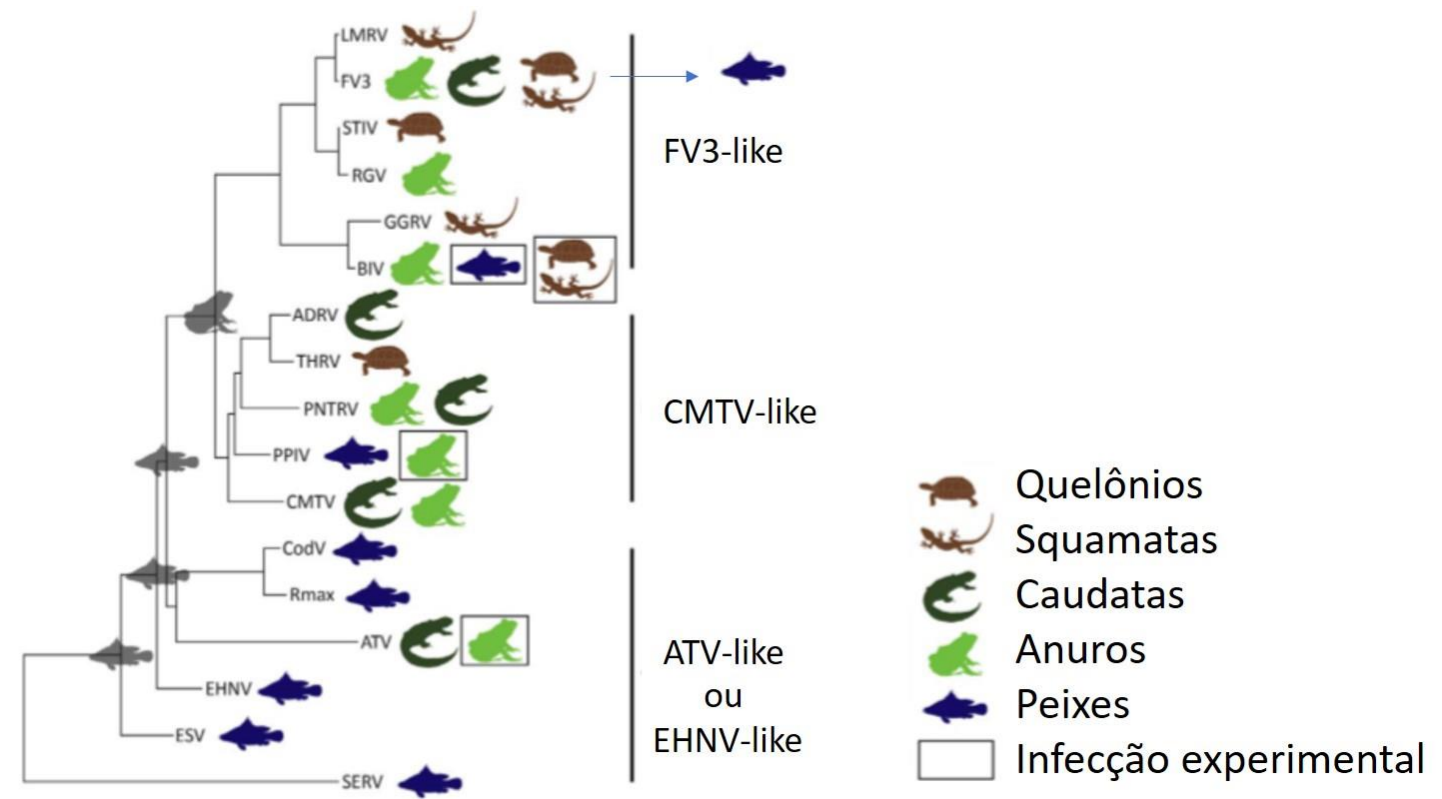

Legenda: Perspectiva filogenética dos hospedeiros de ranavírus no contexto dadiversidade de tipos de virais: FV3-like, anfíbios-like ranavírus, CMTV-like e ATVlike ou ENV-like. Os hospedeiros ancestrais (peixe ou anfíbio) são indicados pela imagem cinza nos nós. Abreviação do isolado: SERV, short-finnedeelranavirus; ESV, European sheat fishvirus; EHNV, Epizootic haematopoietic necrosis virus; ATV, Ambystoma tigrinum virus; Rmax, Ranavirus maximus; CodV, Cod iridovirus; CMTV, common midwife toad virus; PPIV, pike-perch iridovirus; PNTRV, Portuguese newtand toad ranavirus; THRV, Testudo hermanni ranavirus; ADRV, Andrias davidianus ranavirus; BIV, Bohle iridovirus; GGRV, German gecko ranavirus; RGV, Rana grylio iridovirus; STIV, Soft-shelled turtle iridovirus; FV3, Frog virus 3; LMRV, Lacerta monticola ranavirus. Fonte: Adaptado de PRICE, S. J. et al. From fish to frogs and beyond: Impact and host range of emergent ranaviroses. Virology, Waltham, v. 511, p. 272-279. Nov. 2017. 
As ranaviroses podem ser transmitidas naturalmente entre os animais através de vias de infecção diretas ou indiretas, por exemplo, por alimentação, canibalismo, contato direto com animais infectados ou exposição ambiental (água). As infecções porranavírus são sistêmicas, subclínicas ou podem levar a infecções persistentes, envolvendo múltiplos órgãos internos, tais como os rins, fígado, baço e intestino, causando hemorragia, bem como necrose local ou generalizada; e podem levar a altos níveis de morbidade e mortalidade. As manifestações clínicas adicionais são escurecimento da pele e olhos, letargia, natação errática, perda da flutuabilidade, anorexia, apatia e ataxia (GEORGE et al., 2015; WILLIAMS; BARBOSASOLOMIEU; CHINCHAR, 2005).

Indivíduos com infecções subclínicas podem atuar como reservatórios, dificultando a erradicação do vírus, sendo esse tipo de infecção comum em espécies cativas de peixes, representando um problema potencial na indústria aquícola e para animais silvestres (CHOI et al., 2006; HOLOPAINEN, 2012). A mortalidade e morbidade estão diretamente ligadas à dose viral, virulência (dependendo da espécie/cepa do vírus), estágio de desenvolvimento do hospedeiro, espécie de hospedeiro, origem geográfica, resposta imune do hospedeiro, via de transmissão, persistência ambiental e fatores estressores (GRAY; CHINCHAR, 2015). Dessa forma, a infecção por FV3 pode levar à morte de girinos, anfíbios recentemente metamorfoseados e adultos imunodeprimidos, mas na maioria das infecções em anfíbios adultos e saudáveis estas infecções são depuradas pelo sistema imunológicoou causam apenas infecções subclínicas que se resolvem dentro de duas semanas (CHINCHAR et al., KIM et al., 2015; 2017OIE, 2012).

A Organização Mundial de Saúde Animal (World Organisation for Animal Health - OIE) determina que todas as infecções provocadas por ranavírus em anfíbios sejam notificadas pelo órgão nacional competente. Para peixes, a OIE reconhece a espécie EHNV (vírus da necrose hematopoiética epizoótica) como um patógeno de notificação obrigatória (OIE, 2019). A recomendação da OIE, segundo o Manual de Testes de diagnóstico para Animais Aquáticos, para a confirmação de ranavírus como o agente etiológico pode seguir uma série de ferramentas de diagnóstico, sendo o isolamento viral em cultura celular o teste padrão ouro; entretanto, as análises clínicas, citopatológicas, microscopia eletrônica, imuno-histoquímicas, ensaios imunoadsorventes enzimáticos (ELISA) e análises moleculares (PCR e mais 
recentemente sequenciamento de nova geração) devem ser considerados (MILLER et al., 2015; OIE, 2015).

\subsubsection{Ranavírus no Brasil}

No Brasil, as informações sobre a ocorrência de infecções em peixes causadas por ranavírus ainda são limitadas. As primeiras sequências genômicas de ranavírus detectadas em peixes, homólogas aos do vírus FV3, foram identificadas por Almeida-Queiroz et al. (2014) em tilápias do Nilo (Oreochromis niloticus) associadas a surtos sequenciais de mortalidade em pisciculturas de Jaguaribara-CE (maior produtor nacional de peixe em 2014 - IBGE, 2015) e, em pacu vermelho (tambaqui - Colossoma macropomum), oriundo de propriedade com criação de rãs, em Matão-SP. Além disso, Mesquita (2014) detectou positividade para Ranavirus também em tilápia do Nilo criada na água residual do frigorífico de ranário objeto de seu estudo, no estado de Goiás.

Contudo, vários estudos em anfíbios corroboram que o FV3 é o Ranavirus circulante no Brasil. Mazzoni et al. (2009) fizeram o primeiro registro no país; durante o período de 2003 a 2005 investigaram a mortalidade em girinos de L. catesbeianus criados no estado de Goiás, e confirmaram a infecção por FV3 através de técnicas moleculares, histopatológicas e de microscopia eletrônica. Galli et al. (2006) investigando raniculturas uruguaias e brasileiras (próximo a Brasília), a partir da detecção molecular do vírus em girinos, verificaram que as sequências obtidas quando comparadas as de bancos de dados demonstraram elevada homologia com vários membros do gênero, sendo $100 \%$ similares ao FV3.

Mesquita (2014) detectou ranavírus em L. catesbeianus em dois ranários de Goiás, nas cidades de Anápolis e Hidrolândia, por meio do emprego de métodos de diagnóstico como histopatologia, PCR em tempo real, microscopia eletrônica, imunohistoquímica, e associando a presença do vírus a rãs que apresentavam Síndrome Vestibular. Além disso, avaliando animais do entorno dos ranários, verificou por PCR em tempo real, a presença de ranavírus em pererecas nativas, lagartixa e peixe (tilápia citada acima).

Neves et al. (2016) investigaram a presença de ranavírus em três ranários produtores de L. catesbeianus no estado de São Paulo, através de microscopia eletrônica de transmissão, análises histopatológicas e a partir de anticorpos policlonais primários. 
Observaram que partículas virais estavam presentes em 90\%, 65\% e 15\% dos animais adultos dos três locais e em $90 \%$ dos girinos em um dos ranários.

Alencar (2016) realizou o isolamento viral e caracterização de um FV3 (FV3-símile), em cultura celular a partir do tecido hepático de rãs-touro ( $L$. catesbeianus) proveniente de um ranário do interior de São Paulo em período de surto (Figura 5). Ademais, Oliveira et al. (2020) avaliaram a presença de Ranavirus em rãs e girinos, através de técnicas moleculares de amplificação do gene $\mathrm{MCP}$, em oito raniculturas nos anos de 2016 e 2017, sendo seis delas localizadas em cidades do estado de São Paulo, uma no estado de Santa Catarina e uma ranicultura do Rio Grande do Sul. O ranário de Tapiratiba - SP apresentou diagnóstico molecular positivo de 52,2\% para os indivíduos adultos e 50\% para os girinos analisados, destacando-se que a ranicultura estava em surto com cerca de $90 \%$ de mortalidade. Na sequência deste estudo, Tavares (2018) realizou o isolamento viral e caracterização de um novo FV3-símile, a partir do tecido hepático de rãs-touro provenientes de Tapiratiba.

Figura 5 - Imagens de microscopia eletrônica de transmissão da linhagem celular BF-2 infectada com FV3-símile, um isolado brasileiro

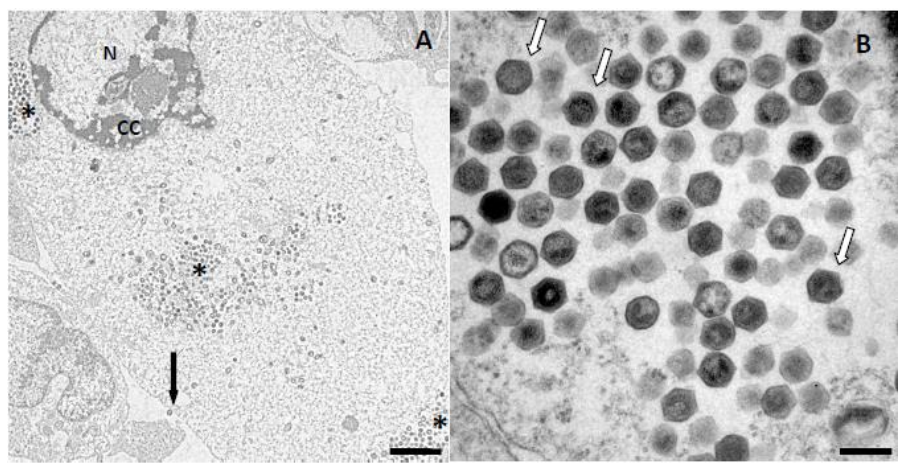

Legenda:A: Núcleo $(\mathrm{N})$, condensação da cromatina (CC), indicativo de apoptose, * locais de montagem das partículas virais e arranjos paracristalinos, seta indicando a saída do vírion por brotamento; Barra $=900 \mathrm{~nm}$. B: Setas indicando vírions icosaédricos, com morfologia indicativa da família Iridoviridae; Barra $=200 \mathrm{~nm}$.Fonte: ALENCAR, A. L. F. Isolamento e caracterização de estirpe de Frogvirus 3-símile detectada em rãs-touro gigante (Lithobatescatesbeianus) no Estado de São Paulo. 2016. 61 f. Dissertação (Mestrado) Faculdade de Zootecnia e Engenharia de Alimentos, Universidade de São Paulo, Pirassununga, 2016.

Ruggeri et al. (2019) fizeram recentemente o relato de ranavírus em anfíbios selvagens na Mata Atlântica. No ano de 2017, no Rio Grande do Sul, foi verificada uma grande mortandade de girinos de rã-touro e alguns peixes em uma lagoa natural, sendo 
que os animais apresentavam sinais característicos de ranaviroses. Em dois locais, próximos ao surto, foram coletados adultos de rã-touro e girinos de duas famílias nativas, Bufonidae e Hylidae; estes foram analisados por qPCR para Ranavirus e para o fungo Batrachochytrium dendrobatidis, os resultados confirmaram a presença do vírus e, portanto, o surto de ranavirose fora de um local de criação. Uma das hipóteses levantadas pelos autores é que o ranavírus tenha se disseminado pela Mata Atlântica a partir de ranários abandonados, que resultou na liberação de animais de produção na natureza (ZIEGLER, 2019) (Figura 6).

Figura 6 - Distribuição de Ranavirus no Brasil, segundo registros da literatura consultada

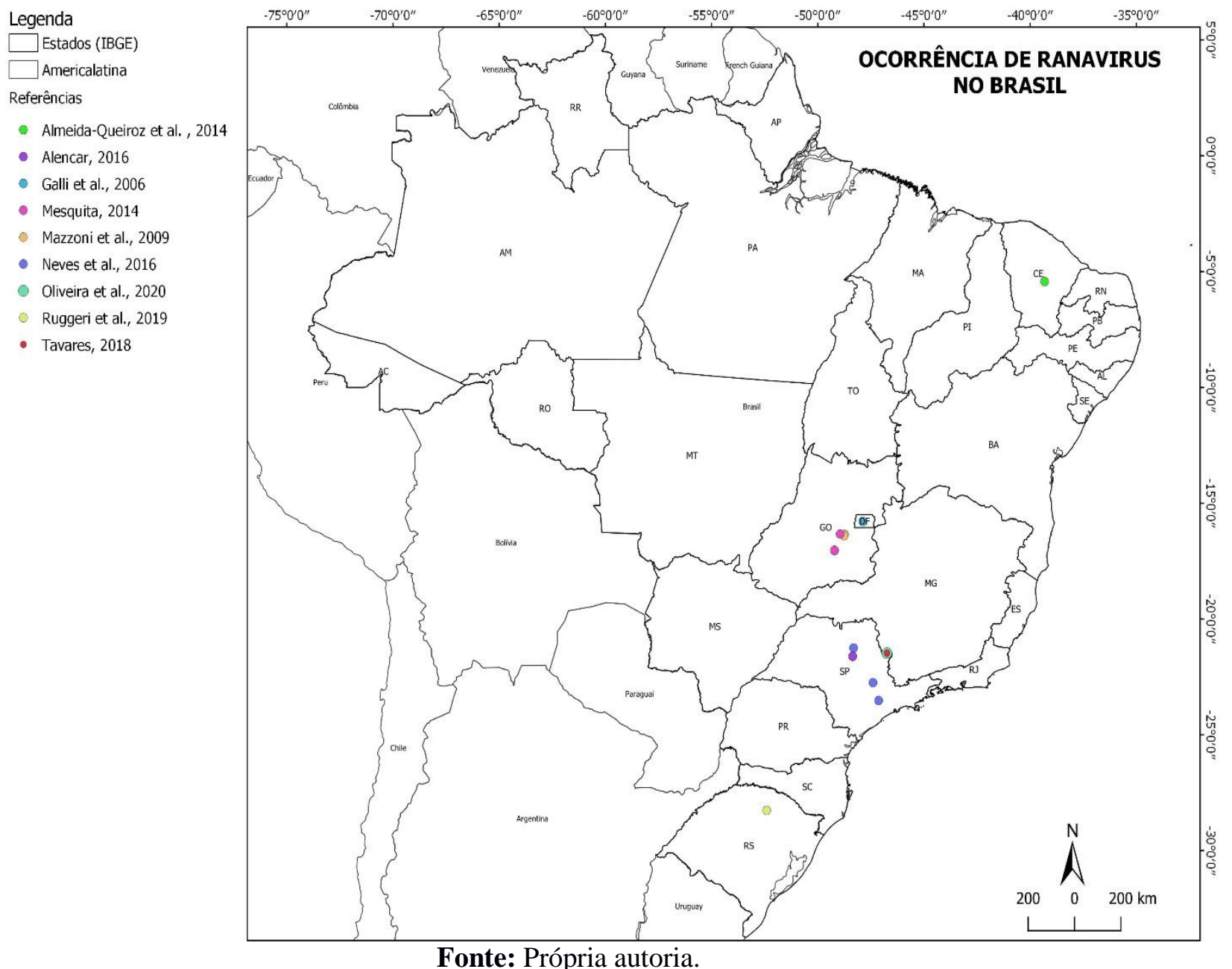

O Ministério da Agricultura, Pecuária e Abastecimento (MAPA) iniciou no ano de 2018 consultas públicas para a criação das novas diretrizes na área de sanidade de organismos aquáticos, visando incluir os patógenos da família Iridoviridae e, 
portanto, as ranaviroses, no Programa Nacional de Saúde Animal. Em tempo, trabalhos sobre a ocorrência de ranavírus no Brasil, como rotina de monitoramento, caracterização viral e estudos genéticos e filogenéticos devem ser intensificados, uma vez que nem todas as classes acometidas foram objeto de estudo, como por exemplo, os quelônios. Além disso, com a literatura disponível neste momento, no Brasil, não é possível identificar ao certo quando e por onde ocorreu a entrada de Ranavirus, apenas sugere-se a hipótese de que a porta de entrada foi a importação de matrizes de $L$. catesbeianus oriundas da América do Norte (MOSTÉRIO, 2019, comunicação pessoal).

\subsection{Testes de diagnóstico}

Na tentativa de contribuir com o diagnóstico e a sanidade das populações cativas e selvagens, vários métodos têm sido desenvolvidos para a detecção viral. Segundo Flores (2007), os testes de diagnóstico devempriorizar algumas características, tais como: sensibilidade, especificidade, rapidez, praticidade, reprodutibilidade, automatização e baixocusto. No diagnóstico virológico, os métodos são classificados em diretos e indiretos; osmétodos diretos são utilizados para detectar o vírus, antígenos ou ácidos nucléicos do vírus; por outro lado, os métodos indiretos detectam anticorpos específicos contra o vírus, ou seja, identificam a resposta do hospedeiro frente à infecção.

Dentre as técnicas diretas temos a detecção viral pela microscopia eletrônica, o isolamento viral em cultivo celular, hemaglutinação ou hemadsorção; a detecção de antígenos virais pelo uso de anticorpos específicos com as técnicas de imuno-histoquímica, imunofluorescência, imunoperoxidase, imunoenzimáticas (ELISA), imunocromatográficas e imunoblot; detecção de ácidos nucléicos com hibridização (Southern, Northern, dot/slot blot), reações em cadeia da polimerase (PCR), quantitative real-time PCR (PCR em tempo real ou qPCR), DNA ambiental (eDNA), LAMP (loop-mediated isothermal amplification) e sequenciamento genômico completo ou parcial. Nos métodos indiretos, destacam-se os sorológicos: a imunodifusão em gel de ágar, ELISA, soroneutralização, fixação do complemento e inibição da hemaglutinação. Os testes diretos e indiretos, por exemplo, moleculares e sorológicos oferecem vantagens diferentes e devem ser considerados complementares e 
não concorrentes (CINKOVA et al., 2010; FLORES, 2007; HOLOPAINEN et al., 2009; JARAMILLO et al., 2017; KIM et al., 2015; MIN et al., 2013; WIRTH et al., 2018).

O teste de ELISA foi desenvolvido na década de 70 e desde então vem sendo adaptado, podendo ser executado através de vários protocolos e variações do mesmo conceito antígeno-anticorpo (Figura 7). É uma técnica de alto nível de sensibilidade, especificidade e reprodutibilidade; além disso, utiliza pequeno volume de reagente e amostragem não letal. À título de exemplo, uma das vantagens importantes de se testar soros por ELISA, em peixes, é que o sangue pode ser coletado facilmente através da veia caudal de muitas espécies; mesmo em peixes menores, é possível coletar amostra suficiente para o teste (JARAMILLO et al., 2017). Ademais, podem indicar uma infecção anterior, muito importante para as ocorrências subclínicas principalmente de ranaviroses e, podem também, ser utilizados na avaliação de eficácia de vacinas (CHOI et al., 2006; HOLOPAINEN, 2012; JARAMILLO et al., 2017).

Figura 7 - Representação esquemática de modelos de ELISA

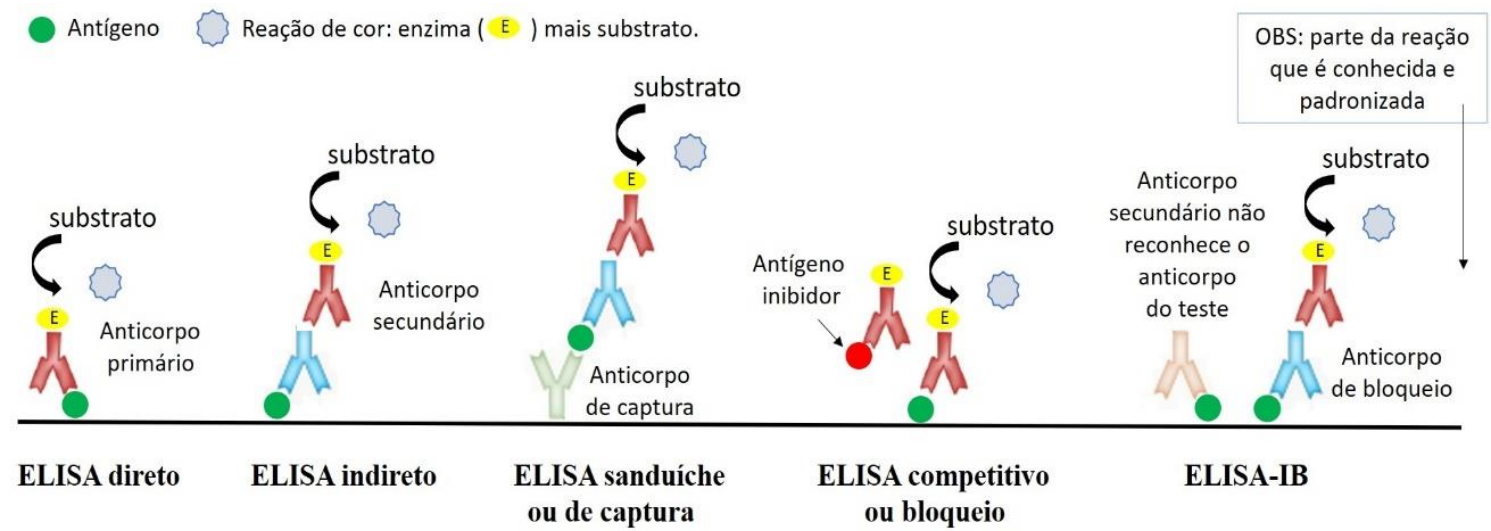

Legenda: No ensaioimunoabsorventeenzimático (ELISA), um antígeno é reconhecido diretamente por um anticorpo marcado ou indiretamente por um anticorpo primário, que em seguida, é reconhecido por um anticorpo secundário conjugado (marcado), que ao entrar em contato com um substrato apresenta coloração. Fonte: Própria autoria.

Uma vez que proteínas estruturais virais podem servir como um antígeno capaz de estimular a resposta imune contra infecções virais, investigações sobre o papel da proteína MCP nos processos patológicos de infecções por ranavírus também têm sido realizadas. Estas requerem a produção in vitro através de clonagem e expressão do gene MCP em sistema de expressão procarioto, uma vez que ouso de proteínas recombinantes 
e/ou peptídeos sintéticos em diferentes testes de ELISA ampliam o diagnóstico sorológico (KIM; JUNG; LEE, 2007; LIU et al., 2015; MAHARDIKA; MASTUTI, 2015). Neste contexto, a produção de anticorpos policlonais pode ser uma alternativa, pois contêm uma mistura de anticorpos que reconhecem diferentes partes da proteína (epítopos).

Cinkova et al. (2010), utilizando anticorpo policlonal de coelho produzido contra o ranavírus European catfish virus (ECV), avaliaram a reatividade desse imunobiológico contra um painel de 9 ranavírus. Ressaltaram que o anticorpo policlonal obtido poderia ser útil como reagente de diagnóstico para o desenvolvimento de ensaios específicos e normalizados para a detecção dos vírus pertencentes ao gênero Ranavirus, a partir de peixes de água doce e anfíbios.

Neste contexto, o desenvolvimento de imunorreagentes necessários para a realização de testes sorológicos, como teste de ELISA, é importante para o rastreamento das doenças infecciosas e as proteínas recombinantes produzidas também podem ser alvo de estudos como potencial imunógeno vacinal contra Ranavirus (CAIPANG et al., 2006; CINKOVA et al., 2010; FU et al., 2012; KIM; JANG; LEE, 2008; LIU et al., 2015). 


\section{OBJETIVOS}

\subsection{Objetivo geral}

Contribuir para o aprimoramento do imunodiagnóstico de ranaviroses em peixes e rãs da aquicultura comercial, assim como das espécies de vida livre do Brasil, através da produção de imunorreagentes e adaptação de um teste ELISA Indireto de Bloqueio (Indirect-Blocking ELISA, ELISA-IB), a partir da variante brasileira de Ranavirus, FV3-símile.

\subsection{Objetivos específicos}

a. Produzir a proteína MCP recombinante (rMCP), através de clonagem e expressão do gene MCP do isolado brasileiro de Ranavirus, FV3-símile, em sistema de expressão procarioto (Escherichia coli);

b. Produzir anticorpos policlonais anti-rMCP em animais de experimentação (coelhos);

c. Padronizar um teste de ELISA-IB para detecção de anticorpos anti-MCP de ranavírus, testando-se a proteína $\mathrm{rMCP}$ e os anticorpos policlonais anti-rMCP como imunorreagentes. 


\section{MATERIAL E MÉTODOS}

A metodologia desenvolvida seguiu três etapas principais, destacadas no fluxograma a seguir:

Figura 8 - Fluxograma de trabalho
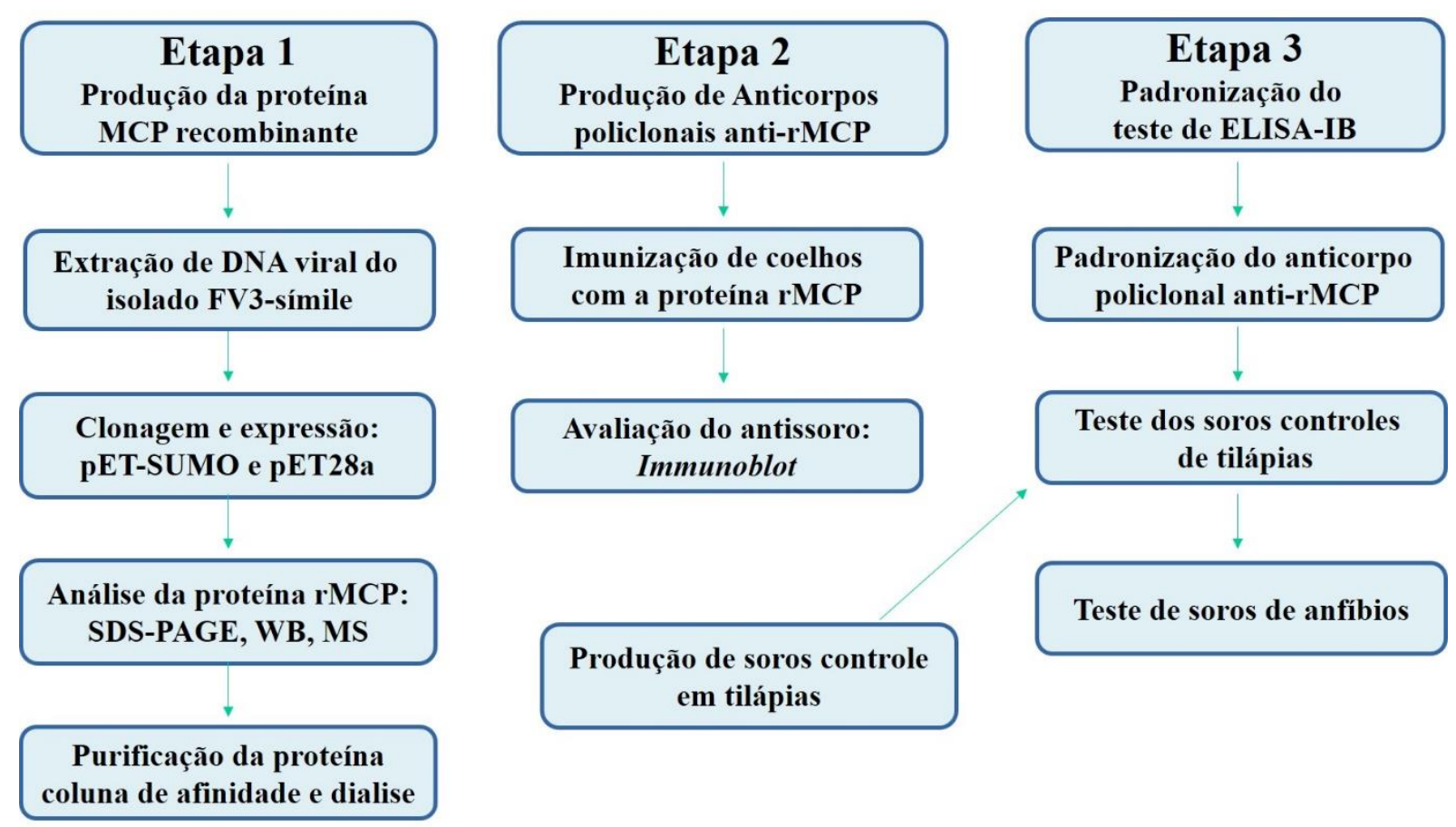

Fonte: Própria autoria.

\subsection{Extração de DNA viral}

Uma garrafa de cultivo celular $75 \mathrm{~cm}^{2}$ contendo células BF-2 (ATCC ${ }^{\circledR} \mathrm{CCL}$ 91 em meio MEM (minimal essential medium) $\left(\mathrm{Gibco}^{\circledR}\right.$, Life Technologies, EUA) [suplementado com $10 \%$ soro fetal bovino (SFB), $1 \%$ de L-Glutamina(Gibco ${ }^{\circledR}$, Life Technologies, EUA), $100 \mathrm{UI} / \mathrm{mL}$ de penicilina e $100 \mu \mathrm{g} / \mathrm{mL}$ estreptomicina $\left(\mathrm{Gibco}^{\circledR}\right.$, Life Technologies, EUA) e $2 \mu \mathrm{g} / \mathrm{mL}$ de Fungizone ${ }^{\circledR}$ (Gibco ${ }^{\circledR}$, Life Technologies, EUA)], foram infectadas com isolado brasileiro de Ranavirus, FV3-símile (GenBank: MH01657), oriundo de rã-touro (L. catesbeianus), isolado por Alencar (2016), 
pertencente ao biobanco do Laboratório de Higiene Zootécnica, do Departamento de Medicina Veterinária da FZEA/USP, Pirassununga, SP.

As células infectadas foram centrifugadas por 10 minutos a $1000 \times g$, sendo o sedimento e o sobrenadante submetidos à extração de DNA utilizando o QIAamp DNA MiniKit (QIAGEN ${ }^{\circledR}$, EUA). A concentração de DNA foi mensurada por espectrofotometria (DeNovix DS-11, EUA), segundo a razão de absorbância $\mathrm{A}_{260} / \mathrm{A}_{280}$, e armazenado a $-20^{\circ} \mathrm{C}$ até o seu uso.

\subsection{Reação em cadeia da polimerase (PCR)}

Foi realizada amplificação do gene MCP completo, 1.392 pb, utilizando os

oligonucleotídeos iniciadores para FV3, MCP-RV-F (5' ATGTCTTCTGTAACTGGTTCA 3' Forward) (MAZZONI et al., 2009) e MCP-RV-R2 (5' TTACAAGATTGGGAATCCCAT 3' Reverse), sendo este último desenhado para o presente estudo, a partir do alinhamento de 14 sequências de Ranavirus depositadas no banco de dados do NCBI (National Center for Biotechnology Information), considerando como sequência principal a da espécie tipo FV3 (AY548484.1) (Tabela 4).

Tabela 4 - Sequências depositadas no GenBank utilizadas para desenho de novo oligonucleotídeo

\begin{tabular}{lc}
\hline Espécie ou isolado & Número de acesso \\
\hline Frog virus 3 & AY548484.1 \\
Frog virus 3 (Mazzoni et al., 2009) & DQ897669.1 \\
Tiger frog virus & AF389451.1 \\
Soft-shelled turtle iridovirus & EU627010.1 \\
Grouper iridovirus & AY666015.1 \\
Rana grylio iridovirus & JQ654586.1 \\
Singapore grouper iridovirus & AY521625.1 \\
Epizootic haematopoietic necrosis virus & FJ433873.1 \\
Ambystoma tigrinum stebbensi virus & AY150217.1 \\
Common midwife toad ranavirus & JQ231222.1 \\
European sheatfish virus & JQ724856.1 \\
Andrias davidianus ranavirus & KC865735.1 \\
Andrias davidianus ranavirus & KF033124.1 \\
Chinese giant salamander iridovirus & KF512820.1 \\
\hline
\end{tabular}

Legenda: Nome da espécie ou isolado e número de acesso no GenBank. Fonte: Própria autoria. 
Para a reação de PCR do gene MCP, foi utilizado o kitGoTaq ${ }^{\circledR}$ Colorless Master Mix 2 (Promega, EUA), conforme as recomendações do fabricante, adicionando-se em cada reação 50ng de DNA, $0,1 \mu \mathrm{M}$ de cada oligonucleotídeo e água livre de nucleases q.s.p. $25 \mu$ L. A reação foi submetida ao processo de termociclagem que compreendeu uma desnaturação inicial de $94^{\circ} \mathrm{C}$ por 5 , , seguido de 30 ciclos de $94^{\circ} \mathrm{C}$ por $30^{\prime}, 58^{\circ} \mathrm{C}$ por $30^{\prime}$, $72^{\circ} \mathrm{C}$ por $1^{\prime}$, finalizando com uma extensão de $72^{\circ} \mathrm{C}$ por 30' (SwiftTM MaxPro Thermal Cycler, Esco Technologies Inc., EUA).

Para avaliar a eficiência da execução do experimento todas as etapas contaram com controles. Como controle de PCR foram utilizados $1 \mu \mathrm{L}$ de Control DNA Template (100 ng), $1 \mu \mathrm{L}$ Control PCR Primers $(0,1 \mu \mathrm{g} / \mu \mathrm{L}$ cada) ambos fornecidos pelo kit Champion ${ }^{\mathrm{TM}}$ pET SUMO Protein Expression System (Invitrogen ${ }^{\mathrm{TM}}$, Thermo Fisher Scientific, EUA), 12,5 $\mu \mathrm{L}$ GoTaq ${ }^{\circledR}$ Colorless Master Mix 2 (Promega, EUA) e água livre de nucleases q.s.p. $25 \mu \mathrm{L}$. A reação foi submetida a termociclagem: desnaturação inicial de $94^{\circ} \mathrm{C}$ por $2^{\prime}$, seguido de 30 ciclos de $94^{\circ} \mathrm{C}$ por $1^{\prime}, 55^{\circ} \mathrm{C}$ por $1^{\prime}, 72^{\circ} \mathrm{C}$ por $1^{\prime}$, finalizando com uma extensão de $72^{\circ} \mathrm{C}$ por $7^{\prime}$ (Swift ${ }^{\mathrm{TM}}$ MaxPro Thermal Cycler, Esco Technologies Inc., EUA).

Os produtos da PCR foram submetidos à eletroforese em gel de agarose a $1,5 \%$ em tampão TAE e verificou-se o tamanho do fragmento através da transiluminação do gel em luz ultravioleta, após coloração em solução de Sybr Gold ${ }^{\circledR}$ (Invitrogen ${ }^{\mathrm{TM}}$, Thermo Fisher Scientific, EUA). Após a confirmação do fragmento esperado para o gene (1.392pb) e para o Controle de PCR (750pb), os produtos foram purificados com auxílio do kit Wizard ${ }^{\circledR}$ SV Gel and PCR Clean-Up System (Promega, EUA), conforme especificações do fabricante.

\subsection{Clonagem e expressão do gene MCP no vetor pET-SUMO}

A clonagem e expressão do gene MCP foi realizada inicialmente utilizandose o kit Champion ${ }^{\mathrm{TM}}$ pET SUMO "Protein Expression System" (Invitrogen, Thermo Fisher Scientific, EUA) (Figura 9), sendo um único vetor de clonagem e expressão, e duas linhagens de E. coli, uma para a etapa de clonagem e outra para a expressão. Conforme as recomendações do fabricante descritas brevemente a seguir nos itens 4.3.1 a 4.3.4. 
Figura 9 - Mapa do vetor de clonagem e expressão pET SUMO

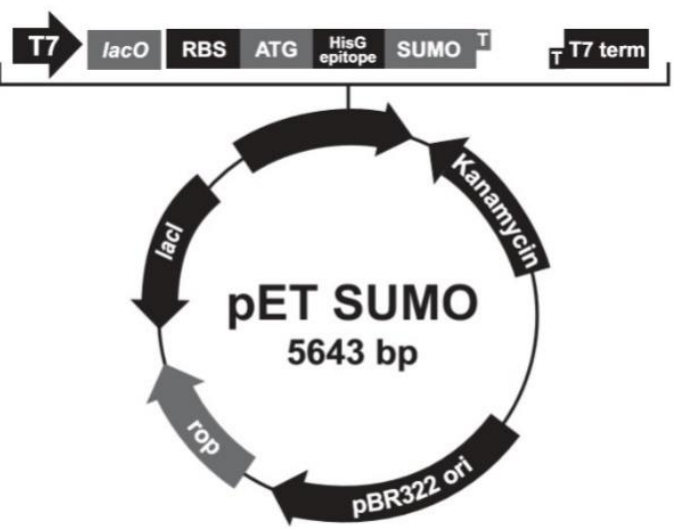

Legenda: Características do vetor pET SUMO: 5643 pares de bases; Promotor T7: 209225; LacOperator (lacO): 228-252; Sítio de ligação do ribossomo (RBS): 282-288; ATG iniciador: 297-299; Epítopo HisG: 309-329; ORF SUMO: 360-653; Sítio para o oligo SUMO foward: 549-571; Sítio de clonagem TA: 653-654; Sítio para o oligo T7 reverse: 783-802 (c); Terminador T7: 744-872; Gene de resistência a canamicina: 1431-2246 (c); Origem pBR322: 2342-3015; ORF ROP: 3383-3574; ORF lacl: (c); (c) = fita complementar. Fonte: Manual Champion ${ }^{\mathrm{TM}}$ pET SUMO "Protein Expression System" (Invitrogen, Thermo Fisher Scientific, EUA) (Manual part no. 25-0709 - MAN0000440).

\subsubsection{Ligação e transformação em OneShot ${ }^{\circledR}$ Mach1 ${ }^{\mathrm{TM}}$-T1R}

$\mathrm{Na}$ etapa de ligação, todos os reagentes foram descongelados em gelo e a reação também foi realizada em gelo. Foram realizadas duas reações de ligação, uma do gene MCP e uma de Controle de ligação com o produto do Controle de PCR. O volume final das reações de ligação foi de $10 \mu \mathrm{L}$, sendo $1 \mu \mathrm{L}$ do produto de PCR purificado na concentração de $25 \mathrm{ng} / \mu \mathrm{L}, 1 \mu \mathrm{L}$ de 10x Ligation Buffer, $2 \mu \mathrm{L}$ de pET SUMO vector (25ng/ $\mu \mathrm{L}), 1 \mu \mathrm{L}$ de T4 DNA Ligase e $5 \mu \mathrm{L}$ de água livre de nucleases. Estas reações foram incubadas a $15^{\circ} \mathrm{C}$ overnight em termociclador (Swift ${ }^{\mathrm{TM}}$ MaxPro Thermal Cycler, Esco Technologies Inc., EUA).

O procedimento de transformação bacteriana foi realizado por choque térmico (Hanahan et al.,1983), sendo a linhagem de E. coli quimicamente competente OneShot ${ }^{\circledR}$ Mach $1^{\mathrm{TM}}-\mathrm{T} 1^{\mathrm{R}}$ utilizada para a clonagem. Tubos contendo as células competentes foram removidos do $-80^{\circ} \mathrm{C}$ e mantidos em gelo para descongelamento lento, em seguida $2 \mu \mathrm{L}$ da ligação foram adicionados em seu respectivo tubo - L: Ligação do MCP, C: Controle de ligação, do fragmento de 750pb do Controle de PCR e UC: Controle de Transformação, plasmídeo circular (uncut plasmid) (plasmídeo 
pUC19) $10 \mu \mathrm{L}$ - agitados gentilmente e colocados em gelo por 30 min. Após este tempo, as células foram submetidas ao choque térmico pela imersão do tubo em banho-maria a $42^{\circ} \mathrm{C}$ por 30 segundos, transferindo-se imediatamente para o gelo. Foram adicionados $250 \mu \mathrm{L}$ de meio S.O.C. (fornecido pelo kit) em temperatura ambiente; estes tubos foram incubados horizontalmente a $37^{\circ} \mathrm{C}$ sob agitação de $200 \mathrm{rpm}$ por 1 hora.

Neste intervalo, placas de Luria-Bertani (LB-ágar) (Anexo I) contendo $50 \mu \mathrm{g} / \mathrm{mL}$ de sulfato de Canamicina (Gibco ${ }^{\circledR}$, Life Technologies, EUA) ou $100 \mu \mathrm{g} / \mathrm{mL}$ de Ampicilina $\left(\right.$ Gibco $^{\circledR}$, Life Technologies, EUA) (apenas para o plasmídeo pu19A, que apresenta resistência a este antibiótico) foram incubadas a $37^{\circ} \mathrm{C}$ por pelo menos 30 minutos. Decorrido o período de incubação das células transformadas, foram semeadas em duplicata, de cada transformação, a placa 1 com $100 \mu \mathrm{L}$ e a placa 2 com $200 \mu \mathrm{L}$ da cultura crescida. As placas foram incubadas em estufa a $37^{\circ} \mathrm{C}$ overnight.

\subsubsection{Análise dos clones recombinantes por PCR e sequenciamento}

As colônias obtidas na transformação de E. coli OneShot ${ }^{\circledR} \mathrm{Mach}^{\mathrm{TM}}-\mathrm{T} 1^{\mathrm{R}}$ foram submetidos ao repique em tubos de 2,0mL contento $1 \mathrm{~mL}$ de meio Luria-Bertani (meio LB) (Anexo I) mais $50 \mu \mathrm{g} / \mathrm{mL}$ de sulfato de Canamicina (Gibco ${ }^{\circledR}$, Life Technologies, EUA), incubadas a $37^{\circ} \mathrm{C}$ overnight sob agitação a $200 \mathrm{rpm}$. No dia seguinte, $600 \mu \mathrm{L}$ da cultura crescida de cada clone foi submetida à extração de DNA plasmidial através do Kit Wizard Plus SV Miniprep DNA Purification System (Promega, EUA), conforme as recomendações do fabricante. Nos $400 \mu \mathrm{L}$ restantes da cultura foram adicionados $20 \%$ de glicerol em cada tubo e armazenado a $-20^{\circ} \mathrm{C}$ como um estoque do clone. O DNA plasmidial obtido a partir da miniprep foi submetido a quantificação por espectrofotometria (DeNovix DS-11, EUA) e armazenado a $-20^{\circ} \mathrm{C}$ até o seu uso.

A análise da presença e posição correta do inserto do gene MCP foi realizada inicialmente com base na amplificação por PCR do gene MCP (descrito anteriormente no item 4.2); as amostras positivas foram submetidas a uma segunda reação de PCR com o par de oligonucleotídeos iniciadores do vetor pET SUMO: SUMO Forward (5' AGA TTC TTG TAC GAC GGT ATT AG 3') e T7 Reverse (5' TAG TTA TTG CTC AGC GGT GG 3’). Para tanto, na reação de PCR do vetor pET SUMO foram utilizados $12,5 \mu \mathrm{L}$ GoTaq ${ }^{\circledR}$ Colorless Master Mix 2 (Promega, EUA), com 
50ng de DNA plasmidial, $0,1 \mu \mathrm{M}$ de cada oligonucleotídeo e água livre de nucleases q.s.p. $25 \mu \mathrm{L}$. A reação foi submetida ao processo de termociclagem com desnaturação inicial de $94^{\circ} \mathrm{C}$ por 5', seguido de 30 ciclos de $94^{\circ} \mathrm{C}$ por $30 ", 60^{\circ} \mathrm{C}$ por 30 ", $72^{\circ} \mathrm{C}$ por 1', finalizando com uma extensão de $72^{\circ} \mathrm{C}$ por $10^{\prime}$ (Swift ${ }^{\mathrm{TM}}$ MaxProThermalCycler, Esco Technologies Inc., EUA).

As amostras positivas para o tamanho do fragmento do inserto do gene MCP mais as extremidades do vetor $(1.645 \mathrm{pb})$ foram submetidas ao sequenciamento, que foi realizado na empresa de biotecnologia $\left.\operatorname{Helixxa}^{\odot}{ }^{(P a u l i ́ n i a / S P}\right)$, através do kit BigDye ${ }^{\mathrm{TM}}$ Terminator v3.1 CycleSequencing Kit (AppliedBiosystems ${ }^{\text {TM }}$, EUA), em sequenciador automático ABI 3500 Series GeneticAnalyzer (AppliedBiosystems ${ }^{\mathrm{TM}}$, EUA). As sequências de nucleotídeos foram compiladas e analisadas pelos programas CodonCode Aligner (CodonCode Corporation, EUA) e BioEdit (HALL, 1999), verificando a posição correta do gene MCP logo após do SUMO.

Foi realizada também a dedução de aminoácidos do gene MCP do FV3símile para comparação com os aminoácidos desta proteína entre as espécies do gênero Ranavirus e com outra sequência brasileira de FV3, depositada por Mazzoni et al. (2009); esta avaliação foi realizada no programa Jalview 2.10.1 (WATERHOUSE et al. 2016).

\subsubsection{Transformação na E.coli de expressão BL21(DE3) OneShot ${ }^{\circledR}$}

Após a confirmação da clonagem, clones pET SUMO/MCP foram selecionados para a transformação em E. coli da linhagem BL21(DE3) OneShot ${ }^{\circledR}$ para a expressão da proteína recombinante (rMCP). A transformação nesta linhagem quimicamente competente também foi realizada por choque térmico (como descrito anteriormente no item 5.3.1); a única diferença sendo que a propagação foi realizada apenas em meio LB. Como controle positivo para esta etapa foi transformado o pET SUMO/CAT, um vetor fornecido pelo kit que expressa a proteína denominada Cloranfenicol Acetil Transferase (CAT) com o N-terminal 6xHis e de aproximadamente $39 \mathrm{kDa}$. 


\subsubsection{Piloto de expressão da proteína rMCP}

Células transformadas da linhagem BL21(DE3) OneShot ${ }^{\circledR}$ contendo o plasmídeo recombinante (pET SUMO/MCP) foram cultivadas em tubos falcon de 50 $\mathrm{mL}$ com $10 \mathrm{~mL}$ de LB e $50 \mu \mathrm{g} / \mathrm{mL}$ de sulfato de Canamicina $\left(\right.$ Gibco $^{\circledR}$, Life Technologies, EUA); este pré-inóculo foi crescido a $37^{\circ} \mathrm{C}$ com agitação a $200 \mathrm{rpm}$ overnight. No dia seguinte, $500 \mu \mathrm{L}$ da cultura foi inoculado em $10 \mathrm{~mL}$ de $\mathrm{LB}$ e $50 \mu \mathrm{g} / \mathrm{mL}$ de sulfato de Canamicina (Gibco ${ }^{\circledR}$, Life Technologies, EUA); após duas horas a $37^{\circ} \mathrm{C}$ e agitação de $200 \mathrm{rpm}$ foi verificada a Densidade Óptica $\left(\mathrm{DO}_{600}\right)$, que deveria estar entre 0,4 a 0,6. Atingida a DO iniciou-se a indução com IPTG (Isopropyl $\beta$-D-1-thiogalactopyranoside) (Promega, EUA) nas concentrações: 0,1mM, 0,5mM e 1mM (Figura 10).

Figura10 - Representação da expressão de proteína recombinante apartir da indução por de IPTG
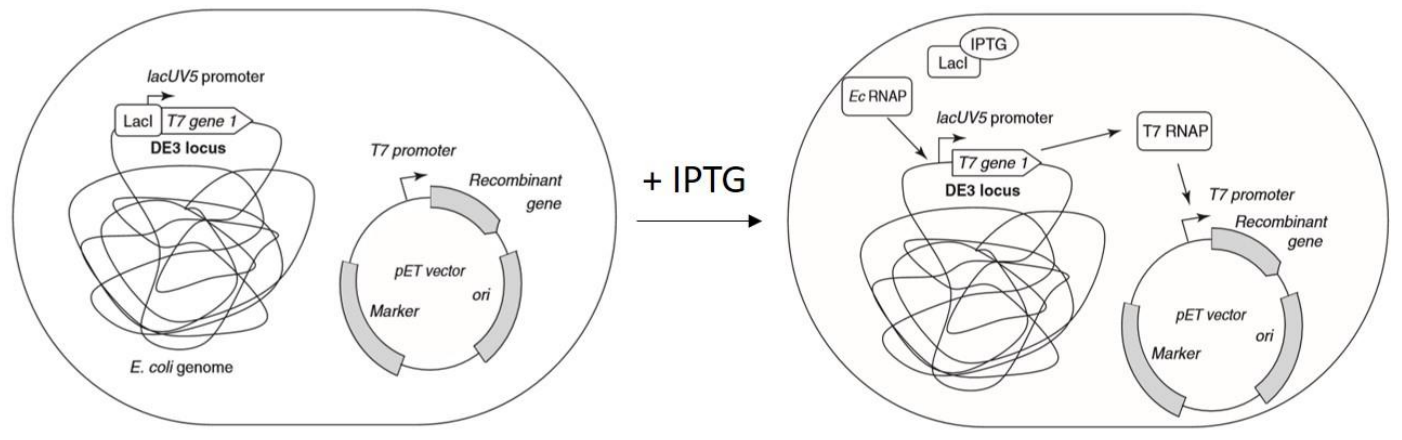

Legenda: Sistema pET de expressão: baseia-se na expressão do gene T7, na presença de IPTG, que por sua vez ativará a expressão das proteínas do vetor pET. Fonte: OVERTON, T. W. Recombinant protein production in bacterial hosts. Drug Discovery Today, London, v. 19 n. 5, p. 590-601, May. 2014.

Foram tomados pontos de tempo, o ponto zero assim que realizada a indução e a cada duas horas ou 4 horas até atingir 24 horas após a indução (denominados t0, t2, t4, t6, t8, t12, t16 e t24). Removeram-se alíquotas de $500 \mu \mathrm{L}$ em tubos de $1,5 \mathrm{~mL}$, que foram centrifugados a $10000 \times g$ por 5 min e armazenados a $20^{\circ} \mathrm{C}$, até análise por eletroforese em gel de poliacrilamida. Além disso, foram induzidos nas mesmas condições o pET SUMO/CAT e a BL21(DE3) OneShot ${ }^{\circledR}$ sem vetor, para servirem como controle de expressão.

Após as primeiras análises do piloto de expressão, este foi repetido com volumes maiores de meio LB, buscando-se, dessa forma, otimizar a expressão para 
maximizar o rendimento de obtenção da proteína. Além disso, o piloto de expressão foi repetido com outras duas temperaturas de $22^{\circ} \mathrm{C}$ e $18^{\circ} \mathrm{C}$, na tentativa de se verificar a cinética de produção da proteína recombinante em condições de metabolismo mais baixo da BL21(DE3) OneShot ${ }^{\circledR}$

\subsection{Clonagem e expressão nos vetores pGEM ${ }^{\circledR}$-T e pET28a (+)}

$\mathrm{Na}$ tentativa de se obter maior expressão da proteína $\mathrm{rMCP}$, uma nova estratégia de clonagem foi adotada, iniciando-se com a clonagem no vetor pGEM $^{\circledR}$-T Easy Vector (Promega, EUA) que possui múltiplos sítios de clonagem, com diversos sítios de enzimas de restrição, compatíveis com a clonagem no vetor de expressão pET28a(+) DNA (Novagen, Merck, Alemanha), gentilmente cedido pelo pesquisador Dr. Paulo S. Monzani (Figura 11). Os sítios escolhidos para corte e ligação foram aqueles sensíveis às enzimas de restrição $N d e \mathrm{I}$ (sentido F) e EcoRI (sentido R).

Figura 11 - Mapa do vetor expressão pET28a(+) DNA

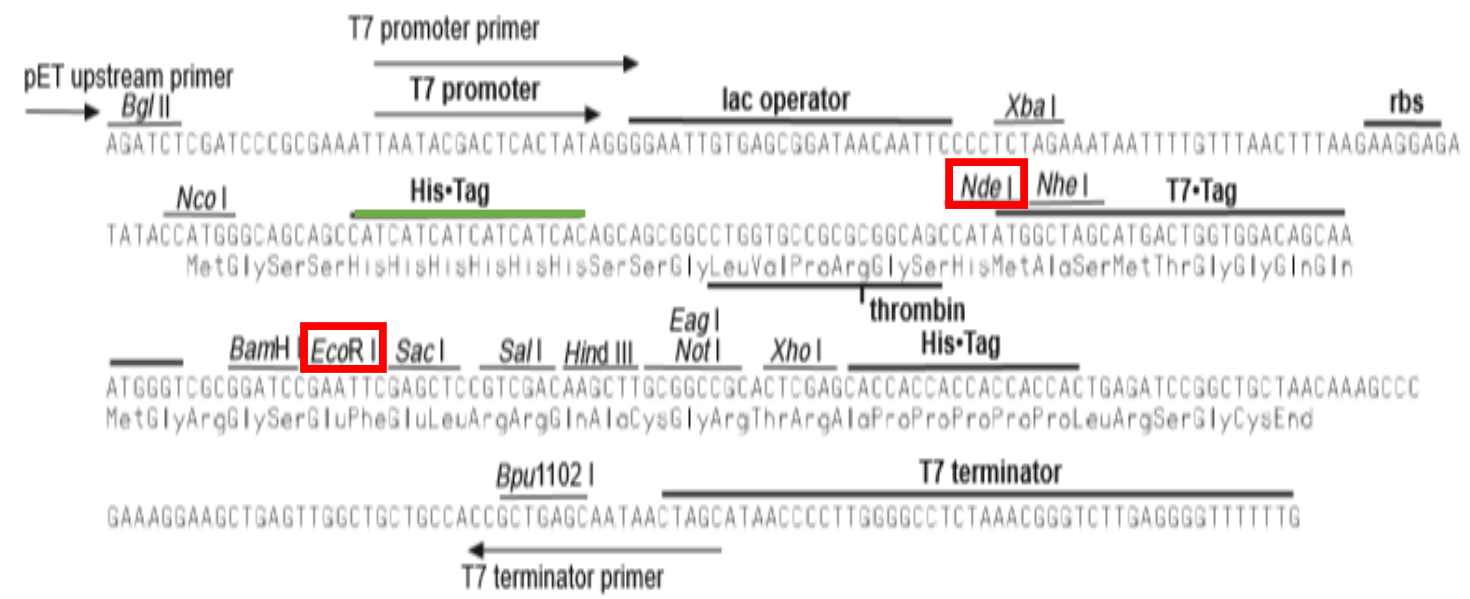

Legenda: Região de clonagem e expressão do vetor pET28a(+), evidenciando os sítios das enzimas escolhidas (vermelho) e a cauda His-tag N-terminal fragmento de 0,84 kDa (verde). Fonte: Adaptado do Manual Novagen, Disponível em: <https://biochem.web.utah.edu/hill/links/pET28.pdf>. Acesso em: 17 set. 2018. 
4.4.1 Amplificação e purificação do gene MCP

Dessa forma, foram construídos dois novos oligonucleotídeos iniciadores para amplificação via PCR do gene MCP com as extremidades contendo os sítios de restrição para as enzimas acima mencionadas, compreendendo $1.398 \mathrm{pb}$, sendo: Pet28MCP-F (5'- CATATGTCTTCTGTAACTGGTTC-3') e Pet28MCP-R (5'GAATTCTTACAAGATTGGGAATCC-3').

A reação da PCR foi a mesma do item 4.2 descrito acima, apenas com o novo par de oligonucleotídeos. A reação foi submetida ao processo de termociclagem que compreendeu uma desnaturação inicial de $94^{\circ} \mathrm{C}$ por 5 , , seguido de 40 ciclos de $94^{\circ} \mathrm{C}$ por $30^{\prime}, 52^{\circ} \mathrm{C}$ por $30^{\prime}, 72^{\circ} \mathrm{C}$ por $1^{\prime}$, finalizando com uma extensão de $72^{\circ} \mathrm{C}$ por 30' (Swift ${ }^{\mathrm{TM}}$ MaxProThermalCycler, Esco Technologies Inc., EUA). Os produtos da PCR foram submetidos à eletroforese em gel de agarose a 1,5\% e verificou-se o tamanho do fragmento através da transiluminação do gel em luz ultravioleta, após coloração em solução de Sybr Gold ${ }^{\circledR}$ (Invitrogen ${ }^{\mathrm{TM}}$, Thermo Fisher Scientific, EUA).

Em seguida, o fragmento de 1.398 pb foi excisado do gel e purificado com auxílio do kit Wizard ${ }^{\circledR}$ SV Gel and PCR Clean-Up System (Promega, EUA), conforme especificações do fabricante. A purificação foi quantificada por espectrofotometria (DeNovix DS-11, EUA), segundo a razão de absorbância $\mathrm{A}_{260} / \mathrm{A}_{280}$, e armazenado a $20^{\circ} \mathrm{C}$ até a utilização na ligação.

\subsubsection{Ligação e transformação no vetor pGEM $^{\circledR}-\mathrm{T}$}

A clonagem no vetor pGEM $^{\circledR}-\mathrm{T}$ (Promega, EUA) foi realizada na proporção de 3:1 (inserto/vetor). Para a reação de ligação, foram misturados $5 \mu \mathrm{L}$ de $2 \mathrm{X}$ Rapid Ligation Buffer, $1 \mu \mathrm{L}_{\text {pGEM }}{ }^{\circledR}-\mathrm{T}$ (50 ng), $3 \mu \mathrm{L}$ do produto purificado da PCR (42ng/ $\left.\mu \mathrm{L}\right)$ e $1 \mu \mathrm{L}$ T4 DNA ligase; a reação foi incubada à temperatura ambiente por quatro horas. Em seguida, foi realizada a transformação por choque térmico, sendo $10 \mu \mathrm{L}$ da ligação adicionados a $100 \mu \mathrm{L}$ de células competentes DH5 $\alpha$, sendo incubados por $20 \mathrm{~min}$ em gelo. Após este tempo, as células foram submetidas ao choque térmico pela imersão do tubo em banho-maria a $42^{\circ} \mathrm{C}$ por 90 segundos, transferindo-se imediatamente para o gelo, sendo adicionados $800 \mu \mathrm{L}$ de Luria-Bertani (meio LB) e incubando-se em estufa a $37^{\circ} \mathrm{C}$ por uma hora. 
Decorrida a incubação, foi realizada uma centrifugação a $3.000 \times g$ por 2 minutos para concentrar as células transformadas. $\mathrm{Na}$ sequência, estas foram homogeneizadas em $200 \mu \mathrm{L}$ de LB e plaqueadas em LB ágar contendo $100 \mu \mathrm{g} / \mathrm{mL}$ de ampicilina (Invitrogen ${ }^{\mathrm{TM}}$, Thermo Fisher Scientific, EUA), $50 \mu \mathrm{L}$ X-gal a $50 \mathrm{mg} / \mathrm{mL}$ e $10 \mu \mathrm{L}$ de IPTG a $1 \mathrm{M}$ (Promega, EUA) (Anexo I); em seguida, foram incubadas a $37^{\circ} \mathrm{C}$ overnight. No dia seguinte, quatro clones foram selecionados para confirmação da clonagem, sendo os clones semeados em $5 \mathrm{~mL}$ de LB com $100 \mu \mathrm{g} / \mathrm{mL}$ de ampicilina a $37^{\circ} \mathrm{C}$, overnight, sob agitação a $200 \mathrm{rpm}$. A miniprep para obtenção do DNA plasmidial foi realizada com o kit Omega EZNA Plasmid DNA mini kit (Omega Bio-Tek, EUA), de acordo com recomendações do fabricante.

\subsubsection{Digestão enzimática, ligação e transformação no vetorde expressão pET28a(+)}

Os plasmídeos $\mathrm{pGEM}^{\circledR}$-T/MCP e o vetor pET28a(+) foram digeridos com as enzimas de restrição NdeI e EcoRI (Invitrogen ${ }^{\mathrm{TM}}$, Thermo Fisher Scientific, EUA), utilizando a seguinte reação: 2,5 a $5 \mu \mathrm{L}$ de DNA plasmidial (dependendo da concentração), $1 \mu \mathrm{L}$ de cada enzima, $2 \mu \mathrm{L}$ de Anza ${ }^{\mathrm{TM}}$ 10x Buffer e água q.s.p. $20 \mu \mathrm{L}$. Para a reação do vetor pET28a(+), foram utilizados $10 \mu \mathrm{L}(110 \mathrm{ng} / \mathrm{mL})$. Os volumes foram homogeneizados lentamente e colocados em banho seco a $37^{\circ} \mathrm{C}$ por $15 \mathrm{~min}$.

A verificação e recuperação dos fragmentos clivados foi realizada em gel de agarose $1 \%$ corado com SYBR ${ }^{\circledR}$ Safe DNA gel stain (Invitrogen ${ }^{\mathrm{TM}}$, Thermo Fisher Scientific, EUA). As bandas do gel contento o vetor pET28a(+), agora linearizado, e o fragmento contendo o gene MCP foram purificados com o kit Omega EZNA ${ }^{\circledR}$ Gel Extraction (OmegaBio-Tek, EUA) de acordo com recomendações do fabricante.

Neste momento, iniciou-se a segunda clonagem do processo, com a ligação do MCP ao vetor de expressão na proporção de 1:1, conforme a reação: $10 \mu \mathrm{L} 10 \mathrm{X}$ Ligase Buffer, $7 \mu \mathrm{L}$ vetor pET28a linearizado $(3,6 \mathrm{ng} / \mu \mathrm{L}), 2 \mu \mathrm{L}$ do fragmento MCP $(14 \mathrm{ng} / \mu \mathrm{L})$ e $1 \mu \mathrm{L}$ T4 DNA Ligase. A reação foi incubada à temperatura ambiente por aproximadamente 4 horas. Logo após, foi realizada a transformação em células competentes DH5a, por choque térmico [como descrito no item 4.1.1.2, com a diferença do antibiótico: $50 \mu \mathrm{g} / \mathrm{mL}$ de sulfato de canamicina (Gibco ${ }^{\circledR}$, Life Technologies, EUA)], com a finalidade de se aumentar a quantidade do vetor construído, $\mathrm{pET} 28 \mathrm{a} / \mathrm{MCP}$. 
No dia seguinte, seis colônias obtidas na transformação foram submetidas a repique em tubos de $5 \mathrm{~mL}$ de meio $\mathrm{LB}$ com $50 \mu \mathrm{g} / \mathrm{mL}$ de sulfato de canamicina (Gibco ${ }^{\circledR}$, Life Technologies, EUA), incubadas a $37^{\circ} \mathrm{C}$ overnight sob agitação a $200 \mathrm{rpm}$. A miniprep para obtenção deste DNA plasmidial foi através do Kit Wizard Plus SV Miniprep DNA Purification System (Promega, EUA), conforme as recomendações do fabricante. Os plasmídeos pET28a/MCP foram submetidos à reação de PCR (conforme descrito no item 4.1.1.1) como forma de controle para confirmar a construção do plasmídeo de expressão com o gene MCP.

4.4.4 Transformação em duas linhagens de E. coli e expressão da proteína rMCP

Após a confirmação da construção do plasmídeo pET28a/MCP, foram realizadas as transformações, por choque térmico, em duas linhagens de E. coli quimicamente competentes: BL21(DE3) OneShot ${ }^{\circledR} \quad$ (Invitrogen $^{\mathrm{TM}}$, ThermoFisherScientific, EUA), utilizada inicialmente no projeto, e a nova linhagem a ser testada, Rosetta ${ }^{\mathrm{TM}}(\mathrm{DE} 3)$ (Novagen, Merck, Alemanha), com o intuito de comparar a expressão de cada linhagem. Para tanto, $100 \mu \mathrm{L}$ de células e $1 \mu \mathrm{L}$ de DNA plasmidial pET28a-MCP ( 30 ng/ $\mu \mathrm{L})$, incubados em $400 \mu$ Lde meio S.O.C. (Invitrogen $^{\mathrm{TM}}$, Thermo Fisher Scientific, EUA), a $37^{\circ} \mathrm{C}$ por 1 hora sob agitação de $200 \mathrm{rpm}$. Em seguida, todo o conteúdo da transformação de cada linhagem, separadamente, foi inoculado em $10 \mathrm{~mL}$ de meio LB com50 $\mu \mathrm{g} / \mathrm{mL}$ de sulfato de canamicina (Gibco ${ }^{\circledR}$, Life Technologies, EUA) e incubados a $37^{\circ} \mathrm{C}$ sob agitação de $200 \mathrm{rpm}$ overnight.

No dia seguinte, foi realizado o piloto da expressão: uma alíquota de $150 \mu \mathrm{L}$ do pré-inóculo foi inoculado em $100 \mathrm{~mL}$ de $\mathrm{LB}$ contendo $50 \mu \mathrm{g} / \mathrm{mL}$ de sulfato de canamicina $\left(\right.$ Gibco $^{\circledR}$, Life Technologies, EUA) e incubado a $37^{\circ} \mathrm{C}$ sob agitação de 200 rpm por cerca de 3 horas, até atingir a Densidade Óptica $\left(\mathrm{DO}_{600}\right)$ acima de 0,6. Neste ponto, as culturas foram induzidas com $1 \mathrm{mM}$ de IPTG (Promega, EUA), e alíquotas de $500 \mu \mathrm{L}$ das culturas foram removidas em diferentes pontos de tempo ( $\mathrm{t} 0, \mathrm{t} 2, \mathrm{t} 4 \mathrm{e} \mathrm{t} 6)$, sendo centrifugadas a $14000 \mathrm{rpm}$ por 5 minutos e armazenados a $-20^{\circ} \mathrm{C}$, com o intuito de se determinar o tempo ideal para níveis mais elevados de expressão da rMCP. 


\subsection{Análise da expressão proteína rMCP}

\subsubsection{SDS-PAGE (Sodium Dodecyl Sulphate - Polyacrylamide Gel Electrophoresis)}

As amostras do piloto de expressão armazenadas em freezer foram descongeladas em gelo. O pellet foi homogeneizado em $500 \mu \mathrm{L}$ de tampão de lise (Anexo I), para a liberação das proteínas. Os tubos foram submetidos ao congelamento rápido em nitrogênio líquido e descongelamento em banho-maria a $42^{\circ} \mathrm{C}$, repetindo por três vezes o processo de congelamento e descongelamento. Em seguida, foi realizada a centrifugação $14000 \mathrm{rpm}$, a $4^{\circ} \mathrm{C}$ por $5 \mathrm{mim}$, sendo o sobrenadante transferido para um novo tubo, uma vez que poderia conter as proteínas solúveis, enquanto o pellet formado, as proteínas insolúveis.

Após a preparação inicial das amostras, volumes do sobrenadante $(75 \mu \mathrm{L}) \mathrm{e}$ do pellet (sedimento total) foram homogeneizados em tampão de amostra, 4X Laemmli (Bio-Rad Laboratories, EUA), diluído segundo a recomendação do fabricante em 2mercaptoetanol (SIGMA-ALDRICH, EUA). Em seguida, foi realizada a fervura a $95^{\circ} \mathrm{C}$ por $5 \mathrm{mim}$, e $10 \mu \mathrm{L}$ de amostra foi aplicada em gel de poliacrilamida $10 \%$ MiniPROTEAN $^{\circledR}$ TGX $^{\mathrm{TM}}$ (Bio-Rad Laboratories, EUA), a 100V em cuba de eletroforese vertical (Bio-Rad Laboratories, EUA) na presença de tampão 1X Tris/Glicina/SDS (Bio-Rad Laboratories, EUA).

Decorrida a separação das proteínas pela eletroforese em poliacrilamida na presença de SDS, o gel foi fixado por $15 \mathrm{~min}$ com solução de fixação (Anexo I) e corado overnight sob leve agitação com Coomassie Brilliant blue R250 Dye (Bio-Rad Laboratories, EUA) (Anexo I). No dia seguinte, foram realizadas sucessivas lavagens sob leve agitação com a solução descoloração (Anexo I) até a visualização das proteínas. Foi utilizado o fotodocumentador ChemiDoc ${ }^{\mathrm{TM}}$ MP Imaging System (BioRad Laboratories, EUA).

\subsubsection{Western Blot (WB)}

A etapa de WB foi realizada após a corrida de um gel SDS-PAGE. A transferência para a membrana Trans-Blot ${ }^{\circledR}$ Turbo $^{\mathrm{TM}}$ Mini PVDF Transfer (Bio-Rad Laboratories, EUA) foi realizada através do sistema turbo de transferência, Trans- 
Blot $^{\circledR}$ Turbo ${ }^{\mathrm{TM}}$ Transfer System (Bio-Rad Laboratories, EUA), segundo as recomendações do fabricante. Após a transferência, a membrana foi lavada rapidamente com tampão 1X TBS-T (Tris-Buffered Saline with Tween-20) (Anexo I); em seguida, bloqueada em $10 \mathrm{~mL}$ 1X TBS-T 5\% BSA (bovine serum albumin) (Anexo I) por uma hora em agitador horizontal tipo gangorra.

Decorrido o bloqueio, a membrana foi incubada overnight a $4^{\circ} \mathrm{C}$ com o anticorpo primário Anti-His-Tag (RheaBiotech - Imuny Anticorpos Nacionais, BR) na diluição de 1:1000, no próprio tampão utilizado no bloqueio. Em determinado momento, passou-se a usar também como anticorpo primário para confirmação de reatividade da proteína $\mathrm{rMCP}$ o anticorpo Anti-Iridovirus capsid protein antibody (ab26808, $\left.\mathrm{AbCam}^{\circledR}, \mathrm{EUA}\right)$, comercialmente descontinuado, mas que foi gentilmente cedido pelas pesquisadoras Dra. Cláudia Maris Ferreira Mostério (Instituto de Pesca SP) e Dra. Ana Maria Cristina Rabello Pinto da Fonseca Martins (Instituto Biológico SP), na diluição de 1:10000.

No dia seguinte, a solução contendo o anticorpo primário foi retirada e a membrana lavada por cinco vezes de dois minutos com 1X TBS-T. Para a diluição de 1:4000 do anticorpo secundário, antiRabbit IgG (RheaBiotech - Imuny Anticorpos Nacionais, BR) foi preparado $1 \mathrm{X}$ TBS-T $1 \%$ BSA (8mL $1 \mathrm{X}$ TBS-T $+2 \mathrm{~mL}$ TBS-T 5\% BSA); a membrana foi incubada por uma hora sob agitação. Na sequência, a membrana foi lavada cinco vezes de dois minutos cada com $1 \mathrm{X}$ TBS-T e revelada com o ClarityMax ${ }^{\mathrm{TM}}$ Western ECL Substrate (Bio-Rad Laboratories, EUA). Para a visualização das bandas foi utilizado o fotodocumentador ChemiDoc ${ }^{\mathrm{TM}}$ MP Imaging System (BioRad Laboratories, EUA).

\subsubsection{Espectrofotometria de Massas}

A espectrometria de massas foi realizada no Laboratório Max Feffer de Genética de Plantas, do Departamento de Genética - ESALQ/USP, conforme o protocolo padronizado pelo laboratório, segundo Shevchenko et al. (2006). O processo de preparação da amostra para a leitura no espectrômetro de massas Synapt G2 HDMS (Waters, EUA) consiste em quatro etapas iniciais realizadas durante três dias: preparação das bandas, digestão com tripsina, eluição dos peptídeos e purificação dos peptídeos por microcoluna de fase reversa ZipTips ${ }^{\circledR} \mathrm{C} 18$ (Millipore - Merck, Alemanha). 
Posteriormente, amostras são injetadas no espectro de massas (LC-MS ${ }^{\mathrm{E}}$ ) e sequenciadas; por fim, ocorre a análise dos dados utilizando software e banco de dados de proteínas (UniProt).

\subsubsection{Preparação das amostras}

Após a expressão do plasmídeo pET28a/MCP em Rosetta ${ }^{\mathrm{TM}}$ (DE3) foi realizado a separação por SDS-PAGE e as bandas de maior intensidade, 50kDa e $35 \mathrm{kDa}$, foram cortadas do gel (pelo menos3 bandas de cada tamanho) com auxílio de uma lâmina de bisturi pequena, estéril, em uma placa de Petri de vidro, estéril, previamente enxaguada com metanol e água Milli-Q; as bandas excisadas foram fragmentadas em fragmentos de aproximadamente $1 \mathrm{~mm}^{3}$ e transferidas para tubos de 1,5 mL com auxílio de uma ponteira.

Em seguida, iniciou-se a descoloração dos fragmentos de gel com $200 \mu \mathrm{L}$ de solução de descoloração [50\% (v/v) de acetonitrila e $25 \mathrm{mM}$ de bicarbonato de amônio (AmBic)], agitação por vórtex e repouso de 5 a $10 \mathrm{mim}$. Este processo foi repetido até a remoção completa do corante, aproximadamente 3 vezes. A solução descolorante foi removida e o gel desidratado com $200 \mu \mathrm{L}$ de acetonitrila $100 \%$ por $10 \mathrm{~min}$; após um spin na centrífuga, foi realizada a remoção completa da acetonitrila. Este processo de desidratação foi repetido por mais uma vez, para que os fragmentos do gel ficassem bem brancos, e para a evaporação completa da acetonitrila, os tubos foram deixados em temperatura ambiente na capelade exaustão por $15 \mathrm{~min}$.

Para a redução, os fragmentos de gel foram reidratados com $40 \mu \mathrm{L}$ de solução de redução (DTT $20 \mathrm{mM}$ ), sendo as amostras incubadas a $56^{\circ} \mathrm{C}$ por $40 \mathrm{~min}$. Após um spin na centrífuga, foi realizada a remoção completa dasolução de redução e realizado o processo de desidratação com $200 \mu \mathrm{L}$ de acetonitrila $100 \%$ por $10 \mathrm{~min}$, seguido de evaporação na capelade exaustão por 15 min.

A alquilação foi realizada adicionando-se $40 \mu \mathrm{L}$ de solução de alquilação (55mM de iodoacetamida) sobre os fragmentos de géis e incubação no escuro, à temperatura ambiente, por 30 minutos. Após este período, foi realizado um spin na centrífuga e a remoção completa da solução de alquilação, os fragmentos de gel foram lavados com $200 \mu \mathrm{L}$ de AmBic 25mM, com auxílio do vórtex, seguido de duas 
desidratações com $200 \mu \mathrm{L}$ de acetonitrila $100 \%$ por 10 mim e de evaporação na capela de exaustão por $20 \mathrm{mim}$.

\subsubsection{Digestão com tripsina}

Antes de iniciar a digestão, foi preparada a solução de tripsina, que deve ser nova e de uso imediato; portanto, alíquotas $(10 \mu \mathrm{L})$ de tripsina $(100 \mathrm{ng} / \mu \mathrm{L})$ que estavam congeladas foram completadas para $50 \mu \mathrm{L}$ com solução de AmBic $50 \mathrm{mM}$ gelada. Assim, a concentração final da enzima foi de $20 \mathrm{ng} / \mu \mathrm{L}$ em cada tubo. Foram adicionados $15 \mu \mathrm{L}$ desta solução de tripsina $(20 \mathrm{ng} / \mu \mathrm{L})$ sobre os fragmentos de géis desidratados e as amostras foram deixadas por 15 minutos a $4^{\circ} \mathrm{C}$ para a penetração da tripsina nos fragmentos. Em seguida, foi adicionado AmBic 50mM até cobrir os fragmentos de géis $(40 \mu \mathrm{L})$. As amostras foram incubadas a $37^{\circ} \mathrm{C}$ por 14 horas.

\subsubsection{Eluição dos peptídeos}

Todas as soluções de eluição apresentadas neste tópico são descritas no Anexo I. A ação da tripsina foi interrompida pela adição de $15 \mu \mathrm{L}$ de solução bloqueadora [5\% (v/v) ácido fórmico $96 \%$ em 50\% (v/v) de acetonitrila]. O sobrenadante $(55 \mu \mathrm{L})$ foi recuperado e transferido para um tubo novo.

Eluição I: volume suficiente de solução de eluição I foi adicionado para cobrir os fragmentos de géis remanescentes nos tubos da digestão (40 $\mu \mathrm{L})$. As amostras foram incubadas por 15 minutos a $40^{\circ} \mathrm{C}$, com agitação (vórtex), a cada 5 minutos. $\mathrm{O}$ sobrenadante foi recuperado e transferido para o mesmo tubo que contém o sobrenadante da digestão e a solução bloqueadora $(=135 \mu \mathrm{L})$. Esta etapa foi repetida por mais uma vez.

Eluição II: volume suficiente de solução de eluição II para cobrir os fragmentos de géis $(40 \mu \mathrm{L})$ foi adicionado. As amostras foram incubadas novamente por 15 minutos a $40^{\circ} \mathrm{C}$, com agitação (vórtex), a cada 5 minutos. $\mathrm{O}$ sobrenadante foi recuperado e transferido para o mesmo tubo que contém o sobrenadante resultante da digestão e eluição $\mathrm{I}(=215 \mu \mathrm{L})$. Esta etapa foi repetida por mais uma vez.

Eluição III: foi adicionado volume suficiente $(40 \mu \mathrm{L})$ de acetonitrila100\% para desidratar os fragmentos de géis. O sobrenadante foi recuperado e transferido para 
o mesmo tubo que contêm os sobrenadantes das eluições anteriores $(=295 \mu \mathrm{L})$. Neste momento, os fragmentos de géis podem ser descartados, pois os peptídeos eluídos estão na solução final, fruto de todos os sobrenadantes recuperados $(\sim 300 \mu \mathrm{L})$.

A solução de peptídeos eluídos foi concentrada em concentrador a vácuo (“Speedvac" - Eppendorf Concentrator 5301), a temperatura ambiente até $1 \mu \mathrm{L}(+/-$ $1 \mathrm{~min} / \mu \mathrm{L})$. As amostras foram armazenadas a $-20^{\circ} \mathrm{C}$ para a próxima etapa.

4.5.3.4 Purificação das amostras de peptídeos para espectrometria de massas SynaptG2 utilizando ZipTips ${ }^{\circledR} \mathrm{C} 18$

Antes da análise MS/MS, os peptídeos precisam ser dessalinizados. Para esse propósito foram utilizadas microcolunasde fase reversa ZipTips ${ }^{\circledR} \mathrm{C} 18$ (Millipore Merck, Alemanha), seguindo as instruções do manual com algumas modificações apresentadas a seguir. As soluções utilizadas nesta etapa estão descritas no Anexo I.

As amostras armazenadas no passo anterior foram ressuspendidas em $10 \mu \mathrm{L}$ ácido trifluoracético (TFA) $0.1 \%$ (v:v) em água Milli-Q eagitadas em vórtex, para ajustar o $\mathrm{pH}$ da amostra de forma a obter-se um $\mathrm{pH}<4.0$.

A dessalinização inicia-se com o equilíbrio da coluna ZipTip ${ }^{\circledR}$ C18. Portanto, ajustou-se a ponteira P10 ZipTip ${ }^{\circledR} \mathrm{C} 18 \mathrm{em}$ uma micropipeta P10. Foram aspirados $10 \mu \mathrm{L}$ da solução I e, na sequência, descartados, sem que o estágio dois da micropipeta fosse acionado. Depois, foram aspirados $10 \mu \mathrm{L}$ da solução II e, na sequência, descartados, sem que o estágio dois da micropipeta fosse acionado. Por último, o equilíbrio foi realizado aspirando-se $10 \mu \mathrm{L}$ da solução III e descartando a solução sem acionar o estágio dois da micropipeta.

Para capturar os peptídeos das amostras ressuspendidas foram realizados dez ciclos de pipetagem (aspirar e dispensar repetitivamente), lentamente e sem acionar o segundo estágio da micropipeta, para garantir a fixação dos peptídeos à coluna. Em seguida, foi realizada a lavagem da coluna, aspirando $10 \mu \mathrm{L}$ e descartando a solução IV por três vezes. Por fim, para a eluição dos peptídeos da coluna ZipTip ${ }^{\circledR}{ }_{\mathrm{C}}$, foram aspirados $10 \mu \mathrm{L}$ da solução II e transferidos para um "vial” de vidro borosilicato Waters Total Recovery Vial - (Walters, EUA). Depois, foram realizados dez ciclos de pipetagem (aspirar e dispensar repetitivamente). As amostras foram secas a vácuo ("Speedvac" - Eppendorf Concentrator 5301), e depois, eluídas em $10 \mu \mathrm{L}$ de 50\% (v/v) 
acetonitrila em água Milli-Q, seguida de nova concentração a vácuo (“Speedvac” Eppendorf Concentrator 5301), à temperatura ambiente até $1 \mu \mathrm{L}(+/-1 \mathrm{~min} / \mu \mathrm{L})$. As amostras foram armazenadas a $-20^{\circ} \mathrm{C}$ para a próxima etapa.

\subsubsection{LC-MS ${ }^{\mathrm{E}}$}

As amostras armazenadas foram ressuspendidas em $20 \mu \mathrm{L}$ de formiato de amônio $20 \mathrm{mM}$ pH10. Os peptídeos foram sequenciados no espectrômetro de massas Synapt G2 HDMS (Waters, EUA), acoplado ao sistema Acquity UPLC M-Class, com tecnologia 1D Simulado (Waters, EUA). Os peptídeos foram capturados por uma coluna Trap 2D Symmetry C18 (5 $\mu \mathrm{m}, 180 \mu \mathrm{m} \times 20 \mathrm{~mm})$ (Waters, EUA). A separação foi realizada com uma coluna de primeira dimensão Acquity UPLC M-Classpeptide BEH C18 (5 $\mu \mathrm{m}, 300 \mu \mathrm{m} \times 50 \mathrm{~mm}$ ) (Waters, EUA) e uma coluna analítica Acquity UPLC $M$ Classpeptide CSH C18 $(1,7 \mu \mathrm{m}, 75 \mu \mathrm{m} \times 150 \mathrm{~mm}$ ) (Waters, EUA). As fases móveis da primeira dimensão foram: solução de formiato de amônio 20 mM pH 10 e acetonitrila. Já na segunda dimensão, os dois eluentes foram: A (100\% água contendo $0,1 \%$ de ácido fórmico) e B (100\% acetonitrila contendo 0,1\% ácido fórmico). Foram injetados $9 \mu \mathrm{L}$ de cada amostra: $50 \mathrm{kDa}$ e $35 \mathrm{kDa}$.

A aquisição dos dados foi realizada em um espectrômetro de massas do tipo quadrupolo-tempo de voo (Q-TOF) Synapt G2 MS, equipado com uma fonte NanoLockSpray operando no modo positivo (Waters, EUA), com ion mobility. Para todas as análises, o espectrômetro de massas operou no modo "V", com poder de resolução típico mínimo de 12500, com a cela de ion mobility ativada. O espectrômetro de massas foi calibrado com [Glu1] fibrinopeptídeo B (GFP) humana $1 \mathrm{pmol}_{\mathrm{g}} \mathrm{L}^{-1}$ e a mesma solução foi empregada para o "lockmass" utilizando-se o íon de dupla carga com uma amostragem a cada 30 segundos. Os experimentos foram realizados no modo $\operatorname{HDMS}^{\mathrm{E}}$ (análise independente de dados) que consiste na aquisição alternada, entre espectros obtidos a baixa $(3 \mathrm{eV})$ e alta $(15-50 \mathrm{eV})$ energia de colisão, aplicadas ao módulo trap do 'T-wave' CID, em presença de gás argônio, que produz íons precursores e produtos em sequência. $\mathrm{O}$ tempo de varredura foi de 0,8 segundos em cada modo, no intervalo de $\mathrm{m} / z$ entre 50 e 2000 . 
4.5.3.6 Análise dos dados gerados na espectrometria de massas

Os espectros de massas foram processados utilizando o software Protein Lynx Global SERVER TM (PLGS) versão 3.0.3, com o banco de dados reverso de E. coli, disponível no UNIPROT (data do download 08 de fevereiro de 2019, 28833 proteínas), acrescida da proteína MCP_FRG3G Major capsid protein (Q67473). Os parâmetros de processamento incluíram: tolerância automática para precursores e íons-produto; mínimo de três íons-fragmento correspondentes por peptídeo; mínimo de 7 íonsfragmento correspondentes por proteína; mínimo de 2 peptídeos correspondentes por proteína; um possível erro de clivagem pela tripsina; carbamidometilação de cisteína como modificação fixa e oxidação de metionina como modificação variável; taxa máxima de descoberta de falso positivo (FDR) a $4 \%$.

\subsection{Purificação da proteína rMCP}

\subsubsection{Expressão em larga escala}

A partir dos resultados observados nos pilotos de expressão optou-se por fazer a expressão em escala apenas com a linhagem Rosetta ${ }^{\mathrm{TM}}(\mathrm{DE} 3)$ (Novagen, Merck, Alemanha). Em erlenmeyrs de $500 \mathrm{~mL}$ foram crescidos 2,5 $\mathrm{mL}$ do pré-inóculo de células contendo o plasmídeo pET28a-MCP em $200 \mathrm{~mL}$ de meio LB com 50 $\mu \mathrm{g} / \mathrm{mL}$ de sulfato de Canamicina $\left(\right.$ Gibco $^{\circledR}$, Life Technologies, EUA). Após aproximadamente 4 horas, com a DO de 1, foi realizada a indução com 1mM de IPTG (Promega, EUA), a expressão foi realizada durante 4 horas. Decorrido este tempo, foram amostradas cinco alíquotas de $1000 \mu \mathrm{L}$ para verificar a expressão e o restante foi centrifugado em falcon de $50 \mathrm{~mL}$ a $5000 \times g$ por 8 minutos a cada centrifugação. O pellet foi armazenado a $80^{\circ} \mathrm{C}$ até processo de lise.

O pellet celular contendo a proteína rMCP foi ressuspendido em $30 \mathrm{~mL}$ de tampão de lise pET-SUMO (Anexo I). Foram realizadas cinco etapas de congelamento a $-80^{\circ} \mathrm{C}$ e descongelamento a $42^{\circ} \mathrm{C}$ para auxiliar a lise celular. Além disso, foi utilizado o

Sonicador de Ponteira Desruptor de Célula Ultrassônico (Uniquegroup, Brasil); a amostra foi sonicada em gelo por 1 minuto com intervalo de 30 segundos por seis vezes, 
na potência de $70 \%$. Prontamente, o material for centrifugado a $5000 \times g$ por $10 \mathrm{~min}$, a fim de separar as proteínas solúveis e insolúveis.

\subsubsection{Purificação desnaturante}

A purificação da proteína rMCP com 6xHis-Tag foi realizada por interação com resina de afinidade composta por níquel, primeiramente com ProBond ${ }^{\mathrm{TM}}$ NickelChelating Resin, do kit ProBond ${ }^{\mathrm{TM}}$ Purification System (Life technologies, EUA). Inicialmente, conforme as instruções do fabricante, adotando-se as três possibilidades de purificação: purificação nativa, purificação híbrida (denominação do kit) e purificação desnaturante. A purificação da rMCP expressa pelo vetor $\mathrm{pET} 28 \mathrm{a} / \mathrm{MCP}$ foi padronizada pelo processo de purificação na condição desnaturante, uma vez que não foi possível a solubilização da proteína produzida.

Brevemente, para esta purificação desnaturante, o pellet resultante da lise por sonicador da expressão em escala foi homogeneizado com $8 \mathrm{~mL}$ de Guanidinium Lysis Buffer, agitado lentamente por 10 minutos e centrifugado a $3000 \times g$ por 15 minutos. O sobrenadante foi então adicionado a coluna ProBond ${ }^{\mathrm{TM}}$ Nickel-Chelating Resin, já preparada conforme as recomendações do fabricante. Na sequência, foram realizadas as etapas de ligação e lavagens com os tampões fornecidos pelo kit, em temperatura ambiente. Em todas as etapas, $20 \mu \mathrm{L}$ foram aspirados dos sobrenadantes para posterior análise por SDS-PAGE. Por fim, para eluição da proteína, foram utilizados 5mL de Denaturing Elution Buffer, sendo coletadas frações de $1 \mathrm{~mL}$ da proteína eluída e realizadas leituras de $\mathrm{DO}_{280}$ em espectrofotômetro (DeNovix DS-11, EUA).

As frações com os maiores picos de absorbância foram reunidas para realização do processo de diálise. Adicionaram-se $2 \mathrm{~mL}$ da eluição em uma membrana Dialysis tubing celulose membrane (SIGMA-ALDRICH, EUA), já hidratada, e imediatamente a membrana foi colocada em 1L tampão de diálise (Anexo I) sob agitação a $4^{\circ} \mathrm{C}$ overnight. No dia seguinte, o tampão foi trocado e deixado por mais aproximadamente 6 horas no processo de diálise. Por fim, a amostra foi recuperada e submetida por uma coluna Amicon ${ }^{\circledR}$ Ultra $0.5 \mathrm{~mL}$ Centrifugal Filters 3kDa (Millipore, Merck, Alemanha), a fim de concentrar a proteína rMCP. 
Visando a obtenção de concentrações e volumes maiores da proteína rMCP foi utilizado um novo kit de purificação desnaturante, Talon ${ }^{\circledR}$ Superflow ${ }^{\mathrm{TM}}$ Metal Affinity Resin (Clontech Laboratories, EUA), segundo as recomendações do fabricante com algumas alterações descritas a seguir. A resina Talon ${ }^{\circledR}$ Superflow ${ }^{\mathrm{TM}}$ foi acomodada em uma seringa de $10 \mathrm{~mL}$, usando-se filtro de papel na parte inferior e superior dos $4 \mathrm{~mL}$ de resina. Com a estrutura fixa e fluxo contínuo por gotejamento (coluna de fluxo de gravidade), após a completa sedimentação da resina, foram adicionados $20 \mathrm{~mL}$ de água destilada. Em seguida, a resina foi equilibrada com $25 \mathrm{~mL}$ de Tampão de equilíbrio (Anexo I). Enquanto a coluna era equilibrada, o pellet de proteínas insolúveis originárias da expressão da proteína rMCP que passou pelo processo de lise e sonicação das células E. coli RosettaTM(DE3) foi homogeneizado a $25 \mathrm{~mL}$ do Tampão de equilíbrio até sua completa dissolução. Todo o conteúdo da amostra clarificada foi adicionado à coluna para a ligação da proteína recombinante à resina; depois, a coluna foi lavada com $40 \mathrm{~mL}$ de Tampão de lavagem (Anexo I).

$\mathrm{Na}$ última etapa, foam adicionados $25 \mathrm{~mL}$ de Tampão de eluição (Anexo I) para a recuperação da proteína $\mathrm{rMCP}$. Na tentativa de realizar o enovelamento (refolding) da proteína que estava em sua forma denaturada e reduzir a concentração de ureia, foi realizado o processo de diálise, sob agitação constante utilizando-se a membrana Dialysis tubing celulose membrane (Sigma-Aldrich, EUA). Foram preparados dois tampões de diálise (Anexo I), sendo que a cada uma hora aproximadamente a molaridade de ureia era reduzida gradativamente, misturando-se proporcionalmente estes tampões, até a concentração desejada. Esse processo de diálise durou cerca de 30 horas e foi interrompido no momento que a proteína iniciou a precipitação.

\subsubsection{Quantificação da proteína rMCP purificada}

A dosagem da proteína rMCP purificada foi baseada no método descrito por Bradford (1976). Para a construção da curva padrão foram utilizados sete padrões de BSA de 0,125 - 2,0 mg/mL do kit QuickStart ${ }^{\mathrm{TM}}$ Bovine Serum Albumin (BSA) Standard Set (Bio-Rad Laboratories, EUA). As leituras foram realizadas em espectrofotômetro de placa no comprimento de onda $595 \mathrm{~nm}$ (Thermo Fisher Scientific, EUA). 


\subsection{Produção de anticorpos policlonaisanti-rMCP}

Para a produção dos anticorpos policlonais anti-rMCP, foi realizada a imunização de 2 coelhos machos da Raça Nova Zelândia, com três meses de vida alojados no Setor de Cunicultura da Divisão Agropecuária (DVAGRO) - FZEA/USP, Pirassununga, SP. Os coelhos foram acomodados em gaiolas individuais, o manejo foi como os demais animais da produção, recebendo água e ração ad libitum.

Foram efetuadas três inoculações da proteína rMCP purificada na concentração de $80 \mu \mathrm{g} / \mathrm{mL}, 60 \mu \mathrm{g} / \mathrm{mL}$ e $40 \mu \mathrm{g} / \mathrm{mL}$, respectivamente, sendo um volume de $1 \mathrm{~mL}$ dividido nas aplicações pelas vias intramuscular e subcutânea, com agulha $25 \times 0,80 \mathrm{~mm}$ com intervalos de 14 dias. Antes das aplicações e sangrias, os animais foram sensibilizados e anestesiados com Acepromazina (Acepram 1\%, Vetnil ${ }^{\circledR}$ ) e Cloridrato de ketamina (Dopalen, Ceva) via intramuscular, pela veterinária Waldelucy K. B. F. da Silva.

Como controle do ensaio, antecedendo à primeira inoculação, foi realizada uma sangria da veia jugular de cerca de $3 \mathrm{~mL}$, com seringa de $5 \mathrm{~mL}$ e agulha $25 \times 0,70 \mathrm{~mm}$, coletando-se assim o soro pré-imune. Após 28 dias, na terceira e última inoculação foi realizada a sangria de prova. Após 14 dias, foi realizada a sangria final. Em todas as colheitas o sangue foi colocado em tubos de vidro e deixado à temperatura ambiente por cerca de oito a dez horas para a coagulação; decorrido este período, os tubos foram colocados na geladeira overnight, para uma maior retração do coágulo e liberação do soro. No dia seguinte, os soros foram coletados e centrifugados a $3000 \times g$ por 10 minutos para a eliminação de qualquer componente celular remanescente. Foram divididas alíquotas de $500 \mu \mathrm{L}$ em tubos de 1,5 mL, sendo estes colocados em banho seco a $56^{\circ} \mathrm{C}$ por 30 minutos para a inativação do sistema complemento. Os soros foram armazenados em freezer $\mathrm{a}-20^{\circ} \mathrm{C}$.

\subsubsection{Avaliação do título dos antissoros por Immunoblot}

A verificação da produção dos anticorpos policlonais anti-rMCP produzidos foi realizada por SDS-PAGE e WB, onde a proteína rMCP foi aplicada em gel de poliacrilamida. A proteína $\mathrm{rMCP}$ purificada $(\sim 1 \mu \mathrm{g} / \mathrm{mL})$ foi homogeneizada na proporção de 4:1 em tampão de amostra, 4X Laemmli (Bio-RadLaboratories, EUA), diluído em $\beta$ - 
mercaptoetanol (Sigma-Aldrich, EUA). Em seguida, foi realizada a fervura a $95^{\circ} \mathrm{C}$ por 5 mim, e $10 \mu \mathrm{L}$ da amostra foi aplicada em gel de poliacrilamida 10\% MiniPROTEAN ${ }^{\circledR} \mathrm{TGX}^{\mathrm{TM}}$ (Bio-Rad Laboratories, EUA); a corrida foi efetuada em cuba de eletroforese vertical a 100V (Bio-Rad Laboratories, EUA), na presença de tampão 1X Tris/Glicina/SDS (Bio-Rad Laboratories, EUA).

Decorrida a separação da proteína pela eletroforese em poliacrilamida na presença de SDS, foi realizada a transferência para a membrana Trans-Blot ${ }^{\circledR}$ Turbo $^{\mathrm{TM}}$ Mini PVDF Transfer (Bio-RadLaboratories, EUA), através do sistema turbo de transferência, Trans-Blot ${ }^{\circledR}$ Turbo $^{\mathrm{TM}}$ Transfer System (Bio-Rad Laboratories, EUA). Após a transferência, a membrana foi cortada para a utilização em diferentes tratamentos com os soros obtidos, como anticorpos primários. Para tanto, a membrana foi lavada rapidamente com tampão 1X TBS-T (Tris-Buffered Saline with Tween-20) (Anexo I); em seguida, bloqueada em 10 mL 1X TBS-T 5\% BSA (bovine serum albumin) (Anexo I) por uma hora em agitador horizontal tipo gangorra. Decorrido o bloqueio, as partes da membrana foram incubadas overnight a $4^{\circ} \mathrm{C}$ com o anticorpo primário, o soro préimune, soro de prova e o soro pós-imunizaçãofinal na diluição de 1:2500, no próprio tampão utilizado no bloqueio.

No dia seguinte, os anticorpos primários foram retirados e as membranas lavadas por cinco vezes de dois minutos com 1X TBS-T. Para a ligação do anticorpo secundário, anti-Rabbit IgG conjugado com peroxidase (RheaBiotech - Imuny Anticorpos Nacionais, BR), foi preparada a diluição de 1:4000 em 1X TBS-T 1\% BSA (8mL 1X TBS-T + 2mL TBS-T 5\% BSA); a membrana foi incubada em temperatura ambiente por uma hora sob agitação. Na sequência, a membrana foi lavada cinco vezes, por dois minutos cada, com $1 \mathrm{X}$ TBS-T e revelada com o ClarityMax ${ }^{\mathrm{TM}}$ Western ECL Substrate (Bio-Rad Laboratories, EUA). Para a visualização das bandas foi utilizado o fotodocumentador ChemiDoc ${ }^{\mathrm{TM}}$ MP Imaging System (Bio-Rad Laboratories, EUA).

\subsection{Produção de soros controles em tilápias (Oreochromis niloticus)}

\subsubsection{Preparação da suspensão viral}

A sexta passagem (P6) do isolado brasileiro de FV3-símile (GenBank: MH01657) foi inoculado em uma garrafa de T150 de células BF-2, (mantidas a $25^{\circ} \mathrm{C}$ e 
$5 \%$ de $\mathrm{CO}_{2}$ em meio MEM (minimal essential medium - Gibco ${ }^{\circledR}$, Life Technologies, EUA) suplementado com $10 \%$ soro fetal bovino (SFB), $1 \%$ de L-Glutamina, 100 $\mathrm{UI} / \mathrm{mLde}$ penicilina e $100 \mu \mathrm{g} / \mathrm{mL}$ estreptomicina e $2 \mu \mathrm{g} / \mathrm{mL}$ de Fungizone ${ }^{\circledR}\left(\right.$ Gibco $^{\circledR}$, Life Technologies, EUA)). Decorridos sete dias, a garrafa passou por um processo de congelamento $\left(-80^{\circ} \mathrm{C}\right)$ e descongelamento (temperatura ambiente) por três vezes; em seguida, todo o conteúdo foi recolhido e centrifugado por $3000 \times g$ por 10 minutos, o sobrenadante foi transferido em alíquotas de 1,5 mL para tubos de $2 \mathrm{~mL}$, constituindo assim a P7, e armazenados em $-80^{\circ} \mathrm{C}$. Para ser utilizada como controle negativo, uma garrafa de células BF-2 passou pelas mesmas condições de dias de cultivo, congelamento, descongelamento e centrifugação que a garrafa infectada; dessa forma, teve seu sobrenadante recolhido para a posterior utilização.

A sétima passagem foi titulada $\left(\right.$ TCID $\left._{50}\right)$ em duas placas de 96 poços contendo monocamadas de células BF-2 a $1,5 \times 10^{4}$, preparadas 24 horas antes da titulação e mantidas em MEM (Gibco ${ }^{\circledR}$, Life Technologies, EUA) suplementado com $10 \%$ de soro fetal bovino (SFB), $1 \%$ de L-Glutamina, $100 \mathrm{UI} / \mathrm{mL}$ de penicilina, $100 \mu \mathrm{g} / \mathrm{mL}$ estreptomicina (PenStrep - Gibco ${ }^{\circledR}$, Life Technologies, EUA) e $2 \mu \mathrm{g} / \mathrm{mL}$ de Fungizone $^{\circledR}\left(\right.$ Gibco $^{\circledR}$, Life Technologies, EUA). Foram realizadas diluições do inóculo viral inicial de $10^{-1}$ a $10^{-8}$, sendo que cada poço contendo a monocamada de células foi inoculado com $50 \mu \mathrm{L}$ de cada diluição, com oito réplicas por placa. No controle negativo, foi adicionado somente meio de manutenção à monocamada.

As placas inoculadas foram incubadas em estufa a $25^{\circ} \mathrm{C}$ durante uma hora para a adsorção das partículas virais. Após este período, foram adicionados $50 \mu \mathrm{L}$ de meio de manutenção composto por MEM (Gibco ${ }^{\circledR}$, Life Technologies, EUA) suplementado com 2\% de SFB, $1 \%$ de PenStrep (Gibco ${ }^{\circledR}$, Life Technologies, EUA), $2 \mu \mathrm{g} / \mathrm{mL}$ de Fungizone ${ }^{\circledR}$ (Gibco ${ }^{\circledR}$, Life Technologies, EUA) e 1\% de L-Glutamina em cada poço; as placas foram então incubadas a $25^{\circ} \mathrm{C}$. A leitura com base no efeito citopático (ECP) na monocamada de cada poço foi realizada no sexto dia de incubação. A TCID $50 / \mathrm{mL}$ foi calculada de acordo com Reed e Muench (1938).

\subsubsection{Manejo das tilápias e inoculação}

Foram obtidas 56 juvenis de tilápias, com peso de 27,85 g $( \pm 3,28)$ e comprimento total de $11,4 \mathrm{~cm}( \pm 0,89)$; estas foram acondicionadas em duas caixas 
d'água de 310 L (sistema fechado) por sete dias para aclimatação. Por todo período do experimento, os dois grupos nas caixas d'água receberam o mesmo manejo; com

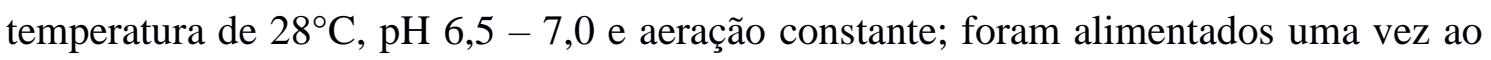
dia até à saciedade aparente, tiveram 50\% da água trocada a cada sete dias, sendo que água retirada dos dois grupos foi tratada com solução à base de cloro $10 \%$ para garantir a descontaminação antes de ser descartada na rede de esgoto. O manejo e colheita de sangue das tilápias foi realizado com o auxílio do zootecnista Dr. Nycolas Levy Pereira.

Após o período de aclimatação, as tilápias das duas caixas foram misturadas e iniciou-se a inoculação dividindo novamente os animais, agora em um grupo controle negativo e um grupo controle positivo (infectado). Foram retirados 4 animais para a colheita do soro pré-imune e dos órgãos (fígado, baço e rim) para a realização de extração de DNA do pool de tecido e PCR (utilizando-se dois marcadores moleculares: MCP2 (MARSH et al., 2002) e ORF53R (1) (CORRÊA et al., 2019) para confirmar a ausência de ranavírus nestes animais antes da infecção experimental.

Foram realizadas duas inoculações intraperitoneais de $100 \mu \mathrm{L}$ do FV3-símile no título de $10^{3} \mathrm{TCID}_{50} /$ peixe, a cada 14 dias, assim como no grupo controle onde foram inoculados $100 \mu \mathrm{L}$ de meio MEM, ou seja, o sobrenadante do cultivo celular de BF-2; para tanto foram utilizadas seringas de $1 \mathrm{~mL}$ com agulha $27,5 \mathrm{G}(0,38 \times 13 \mathrm{~mm})$. Antes da segunda imunização, foram retirados três animais de cada grupo, para a colheita de soro de prova e obtenção dos órgãos. Após 14 dias, uma última inoculação foi realizada, com $10^{4}$ TCID 50 peixe. Antes de qualquer procedimento com as tilápias, elas foram sensibilizadas com Eugenol na concentração de anestesia e/ou eutanásia, conforme o procedimento a ser realizado, como a imunização ou colheita de material.

Decorridos os últimos 14 dias, foi retirado o sangue de todos os animais, para a obtenção do soro, os animais foram eutanasiados e os tecidos retirados para a realização da PCR. Além disso, alguns exemplares tiveram os órgãos (fígado, baço e rim) fixados em formol 10\% para análises histológicas que foram realizadas no Instituto Biológico de São Paulo.

O procedimento de colheita de sangue foi realizado conforme recomendado por Ishikawa et al. (2010), com seringas de $3 \mathrm{~mL}$ e agulhas de $21 \mathrm{G} \times 11 / 4$ ” $(30 \times$ $0,8 \mathrm{~mm}$ ), por venopunção caudal com a agulha inclinada no ângulo de $45^{\circ}$ e penetração em direção à região da coluna vertebral, onde se localizam a veia e artéria caudais. $\mathrm{O}$ sangue foi transferido para tubos de $1,5 \mathrm{~mL}$ para a coagulação em temperatura 
ambiente, seguida de centrifugação a $3000 \times g$ por 10 minutos, o soro foi transferido para tubos novos e colocado em banho-maria a $56{ }^{\circ} \mathrm{C}$ por 30 minutos para inativação do sistema complemento; em seguida, foi armazenado em freezer a $-20{ }^{\circ} \mathrm{C}$.

\subsection{Teste de Elisa-IB}

No teste de ELISA-IB, a proteína rMCP foi utilizada como antígeno viral (AV) específico para a detecção de anticorpos anti-ranavírus em soros de peixe e anfíbios; o antígeno controle (Ac) consistiude uma suspensão de extrato de $E$. coliRosetta $^{\mathrm{TM}}$ (DE3). O método foi baseado no ELISA de bloqueio de fase líquida de Esterhuysen, Prehaud, Thomson (1995), onde a densidade óptica máxima (DOMÁx) foi obtida pela subtração da média da densidade óptica negativa (DONEG), ou seja, a DO do Ac, pela média da densidade óptica positiva (DOPos), ou seja, a DO do AV; sendo ambos na ausência de soros testes, o que representaria a reatividade máxima (100\% de ligação) do anticorpos de bloqueio (policlonalanti-rMCP).

\subsubsection{Padronização do anticorpo de bloqueio - anticorpo policlonalanti-rMCP}

Foram testadas três concentrações de proteína rMCP, sendo a concentração ótima para o AV determinada pela menor concentração capaz de produzir, ao final do ensaio, a maior densidade óptica (DOMÁx), portanto, já descontada a DO correspondente das cavidades contendo como antígeno o extrato de E. coli. As três concentrações da proteína $\mathrm{rMCP}$ foram: $1 \mu \mathrm{g} / \mathrm{mL}, 2,5 \mu \mathrm{g} / \mathrm{mL}, 5 \mu \mathrm{g} / \mathrm{mL}$; frente às diluições do anticorpo policlonal anti-rMCP em seis concentrações (1:50, 1:100, 1:200, 1:400, 1:800 e 1:1000).

O ensaio imunoenzimáticofoi realizado em microplacas de fundo chato de 96 cavidades (Costar 3590, Corning Incorporated, EUA) sensibilizadas com a proteína rMCP diluída em tampão Carbonato-Bicarbonato 0,05M pH 9,6, num volume de $100 \mu \mathrm{L}$ por cavidade, na metade superior de cada microplaca. Semelhantemente, procedeu-se a adição do Ac, nas mesmas concentrações do AV, nas cavidades correspondentes da metade inferior de cada microplaca, no volume de $100 \mu \mathrm{L}$. As microplacas foram incubadas a $4^{\circ} \mathrm{C}$, por 18 horas, em câmara úmida.

Após esse período, as microplacas foram lavadas por quatro vezes com $1 \mathrm{X}$ PBS-T (Anexo I), entre todas as fases do experimento, as microplacas foram submetidas 
a este mesmo tratamento de lavagem. Na sequência, foi realizado o bloqueio com adição de $100 \mu \mathrm{L}$ de PBS-T + BSA 5\% (Anexo I), a $37^{\circ} \mathrm{C}$ por 1 hora, em câmara úmida. Decorrido o bloqueio, as microplacas receberam $100 \mu \mathrm{L}$ do anticorpo policlonal antirMCP diluído em PBS-T + BSA $1 \%$, as placas foram incubadas a $37^{\circ} \mathrm{C}$ por 1 hora, em câmara úmida. Na sequência, após a lavagem, foi adicionado o anticorpo secundário, anti-Rabbit IgG conjugado com peroxidase (RheaBiotech - Imuny Anticorpos Nacionais, BR), diluído a 1:5000 em de PBS-T + BSA 1\%, num volume de 100 $\mu \mathrm{L}$. Novamente, as placas foram incubadas a $37^{\circ} \mathrm{C}$ por 1 hora, em câmara úmida.

Finalmente, após a lavagem das microplacas, foram adicionados $100 \mu \mathrm{L}$ por cavidade do substrato TMB (3,3',5,5'-Tetramethylbenzidine) (Sigma-Aldrich, EUA), as mesmas foram mantidas à temperatura ambiente na câmera úmida, durante no máximo 30 minutos e, a seguir, bloqueadas com $50 \mu \mathrm{L}$ de uma solução de $\mathrm{HCl} 2 \mathrm{M}$. A leitura das densidades ópticas (DO) de cada cavidade das microplacas foi realizada em um leitor de microplacas Thermo Scientific Multiskan GO (Thermo Fisher Scientific, EUA) com o auxílio do software SkanIt RE 4.0 (Thermo Fisher Scientific, EUA) no comprimento de onda de $370 \mathrm{~nm}$, em três tempos (20 min, $25 \mathrm{~min}$ e $30 \mathrm{~min}$ ) até a determinação do tempo de reação, contra o branco unicamente de TMB. Após o bloqueio a leitura foi realizada a 450nm, contra branco constituído pelo substratoenzimático e bloqueador.

A figura 12 representa esquematicamente as ligações que são esperadas em cada poço durante a padronização da DOMÁx do anticorpo policlonal anti-rMCP, obviamente ocorrem várias ligações em um único poço; assim o esquema demostra apenas uma ligação para facilitar a compreensão da ligação máxima que o anticorpo de bloqueio pode atingir. Espera-se que ocorram ligações inespecíficas no Ac, por isso os valores de DO dele devem ser descontados das DO encontradas nas ligações específicas do anticorpo de bloqueio com o AV. 
Figura 12 - Representação esquemáticado ELISA, na padronização do anticorpo de bloqueio

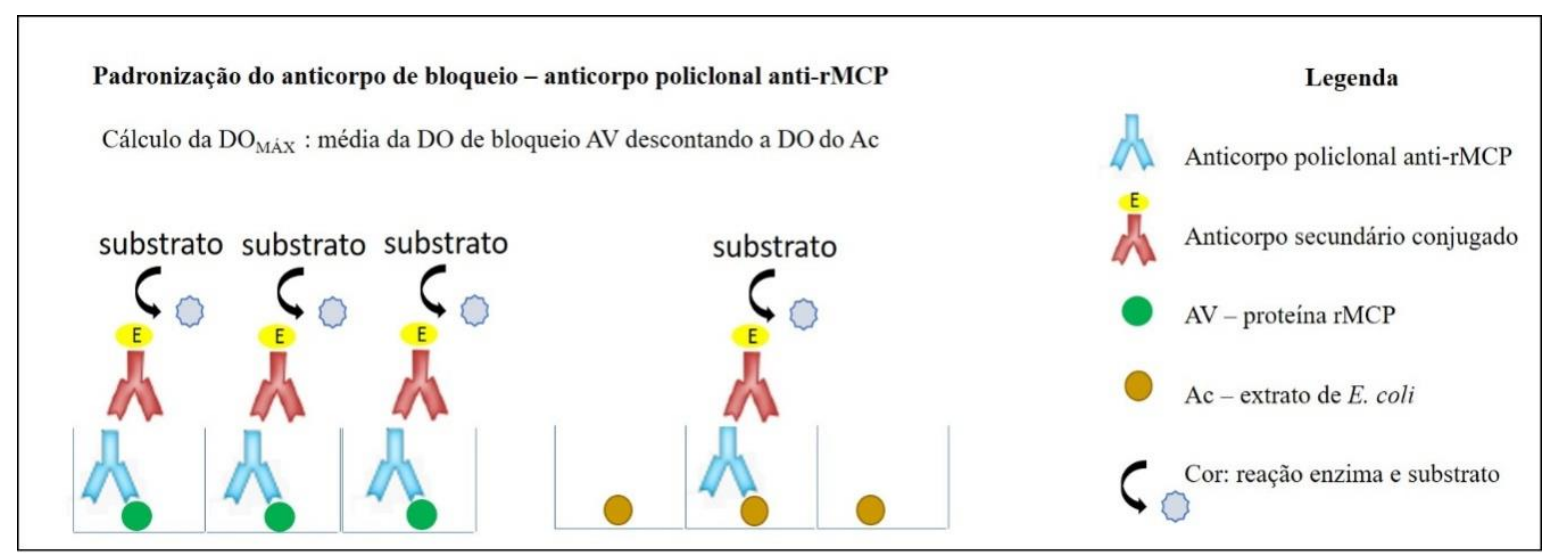

Legenda: exemplo de apenas uma ligação por poço. Fonte: Própria autoria.

\subsubsection{Padronização do Elisa-IB através da titulação dos soros de tilápias}

Após a definição das condições ótimas do AV e do anticorpo de bloqueio (policlonal anti-rMCP), foram testadas quatro diluições de soros sabidamente positivos e negativos (1:50, 1:100, 1:200 e 1:400) frente ao anticorpo secundário anti-Rabbit IgG conjugado com peroxidase (RheaBiotech - Imuny Anticorpos Nacionais, BR) (na diluição padrão de 1:5000), sendo a diluição ótima do soro a ser empregada aquela com a maior diferença de leitura entre os positivos e negativos na concentração ótima do AV.Os soros foram testados em duplicata, sendo os resultados expressos, portanto, em DO média.

As microplacas de fundo chato de 96 cavidades (Costar 3590, Corning Incorporated, EUA) foram sensibilizadas com o AV em tampão Carbonato-Bicarbonato $0,05 \mathrm{M}$ pH 9,6, num volume de $100 \mu \mathrm{L}$ por cavidade, na metade superior, e da mesma forma na cavidade inferior, a sensibilização com o extrato de E. coli (Ac), nas mesmas concentrações do AV. As microplacas foram incubadas a $4^{\circ} \mathrm{C}$, por 18 horas, em câmara úmida.

No dia seguinte, após as quatro lavagens com $1 \mathrm{X}$ PBS-T, foi realizado o bloqueio com adição de $100 \mu \mathrm{L}$ de PBS-T + BSA $5 \%$, a $37^{\circ} \mathrm{C}$ por 1 hora, em câmara úmida. Em seguida, foram adicionados $100 \mu \mathrm{L}$ de soro de peixe, positivos e negativos diluídos em PBS-T + BSA 1\%, em duplicatas, e foram incubados a $37^{\circ} \mathrm{C}$ por 1 hora em câmara úmida. 
Na etapa seguinte, as microplacas foram lavadas e adicionam-se $100 \mu \mathrm{L}$ do anticorpo policlonal anti-rMCP, anticorpo de bloqueio, diluído na concentração determinada anteriormente, em PBS-T + BSA $1 \%$, a $37^{\circ} \mathrm{C}$ por 1 hora, em câmara úmida. Decorrida esta incubação e, após a lavagem, foi adicionado o anticorpo secundário, anti-Rabbit IgG conjugado com peroxidase (RheaBiotech - Imuny Anticorpos Nacionais, BR), diluído a 1:5000 em PBS-T + BSA 1\%, num volume de $100 \mu \mathrm{L}$. Novamente, as placas foram incubadas a $37^{\circ} \mathrm{C}$ por 1 hora, em câmara úmida.

Por fim, após a lavagem das microplacas, foram adicionados $100 \mu \mathrm{L}$ por cavidade do substrato enzimático TMB (3,3',5,5'-Tetramethylbenzidine) (SigmaAldrich, EUA); as mesmas foram mantidas à temperatura ambiente em câmera úmida, durante no máximo 30 minutos e, depois, bloqueadas com $50 \mu \mathrm{L}$ de uma solução de $\mathrm{HCl} 2 \mathrm{M}$. A leitura das densidades ópticas (DO) de cada cavidade das microplacas foi realizada em leitor de microplacas no comprimento de onda de $370 \mathrm{~nm}$, contra o branco unicamente de TMB. E após o bloqueio, a leitura foi realizada a 450nm, contra branco constituído pelo TMB e bloqueador.

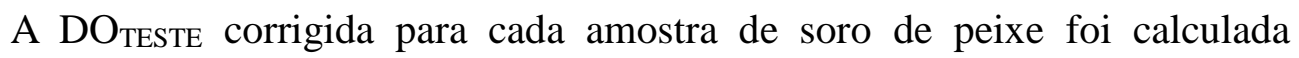
através da subtração da DO obtida na cavidade revestida pelo AV do valor da DO obtida na cavidade revestida pelo Ac. A partir da DOMAX, determinada em cada placa, foram calculadasas porcentagens de inibição (PI) proporcionada por cada soro teste sobre a reatividade máxima que os anticorpos de bloqueio apresentam se soros testes não são empregados, dessa forma a redução da DOMAX obtida refletiria a quantidade de anticorpos anti-ranavírus presentes na amostra (DOTESTE). Segundo a fórmula I de Esterhuysen, Prehaud e Thomson (1995):

\section{PI $=\underline{\text { DO }_{\text {MÁX }}-\text { DO }_{\text {TESTE }}} \times 100$ \\ DOMÁx}

Fórmula I

O ponto de corte (“cutoff”) foi dado a partir da determinação da porcentagem de inibição (PI). Considerou-se a média de PI obtida para os soros controles negativos mais três desvios padrão (média + 3SD) (LIBEAU et al., 1995). 
Valores de PI acima desse ponto de corte indicariam resultados positivos, enquanto valores abaixo indicariam resultados negativos.

A figura 13 traz a representação do que deveria ser observado quando ocorre a presença de anticorpos anti-ranavírus nos soros avaliados. Estes anticorpos presentes na amostra, no caso de IgM piscícola, se ligam ao AV presente na placa, ou seja, os sítios de ligação da proteína rMCP ficariam ocupados, e quando adicionado o anticorpo de bloqueionem todos os sítios de ligação estariam disponíveis. Como o anticorpo secundário com a peroxidase só reconhece o anticorpo policlonal ocorre a redução da intensidade da DO. Quando as DO revelaria presença de anticorpos anti-ranavírus na amostra. Sempre, é claro, descontando as possíveis ligações inespecíficas com o Ac de cada soro respectivamente.

Figura 13 - Representação esquemática do ELISA-IB, na avaliação dos soros teste

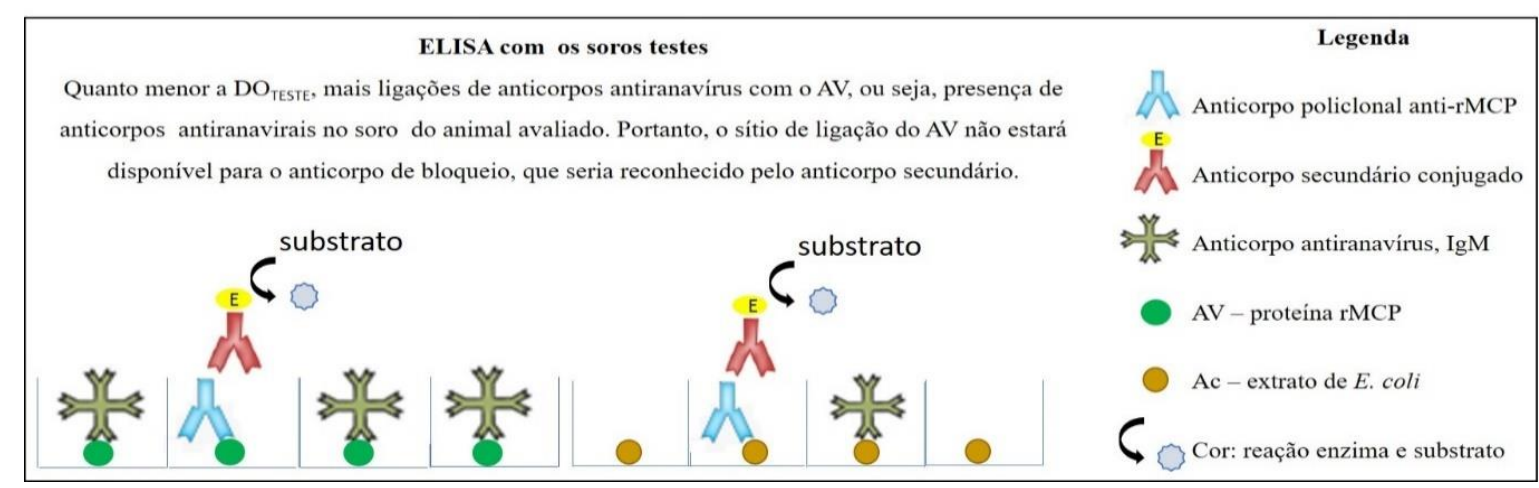

Legenda: exemplo de apenas uma ligação por poço. Fonte: Própria autoria.

4.9.3 Elisa-IB utilizando soros de anfíbios

Para testar o ELISA-IB em anfíbios, foram obtidos soros de seis indivíduos de rãs-touro (L. catesbeianus) de uma região endêmica de FV3 no estado de São Paulo, com o auxílio da equipe de monitoramento do Instituto de Pesca -SP, coordenados pela pesquisadora Dra. Cláudia Maris Ferreira Mostério.

Os indivíduos foram escolhidos aleatoriamente priorizando os animais mais velhos do ranário, uma vez que a propriedade estava em fase de recria no momento da visita e, as rãs não apresentavam sinais clínicos aparentesderanaviroses ou acometidos por outras doenças. A colheita de sangue foi realizada por venopunção na pata traseira com seringas de $1 \mathrm{~mL}$ e agulhas de $21 \mathrm{G} \times 1$ 1/4" $(30 \times 0,8 \mathrm{~mm})$. Obteve-se cerca de 800 $\mu \mathrm{L}$ sangue decada um dos seis indivíduos selecionados, após o processo de coagulação 
o material foi transportado ao laboratório em caixa de isopor resfriada com gelo, para a separação do soro dos componentes celulares foi realizada a centrifugação a $3000 \times g$ por 10 minutos; os soros foram transferidos para tubos novos e armazenados em freezer $\mathrm{a}-20^{\circ} \mathrm{C}$.

O ELISA-IB seguiu a mesma metodologia empregada com os soros de peixe, descrita no o item 4.9.2. Apenas neste caso, foram testadas duas diluições para os soros de rã-touro (1:50, 1:100) e duas concentrações do AV. Foram calculadas as PI de cada amostra.

\subsection{Análise dos resultados}

Foram realizadas análises qualitativas da proteína rMCP e do soro policlonal anti-rMCP. As análises estatísticas (médias, desvios-padrão) dos experimentos foram realizadas utilizando o programa Bioestat (AYRES et al., 2007), com nível de significância de 5\% (valor de $\mathrm{p}<0.05$ ).

\subsection{Aspectos Éticos}

Este projeto foi aprovado pelo Comitê de Ética em Pesquisa da Faculdade de Zootecnia e Engenharia de Alimentos (USP/FZEA), sob o número CEUA No 2265041116. Todos os esforços foram realizados para minimizar o sofrimento dos animais utilizados, de acordo com a Lei Federal 11.794/2008 (BRASIL, 2008). 


\section{RESULTADOS}

\subsection{Extração do DNA viral}

A garrafa de BF-2 com confluência superior a $85 \%$, foi inoculada com $150 \mu \mathrm{L}$ de FV3-símile, da sexta passagem (P6), título $10^{6.8} \mathrm{TCID} / \mathrm{mL}$. Após 24 horas, foi possível verificar efeito citopático e em 48 horas todas as células estavam mortas (Figura 14). Amostraram-se alíquotas, em tubos de 1,5mL, com o volume total da garrafa contendo meio de cultivo, material celular da BF-2 e partículas virais. Estas alíquotas foram submetidas à centrifugação, como especificado anteriormente (item 4.1), sendo o sobrenadante e o sedimento formado (pellet) submetidos à extração de DNA.

Observou-se que a extração do pellet apresentava maiores quantidades de DNA, uma vez que o DNA celular também estava presente. Além disso, estas amostras demonstraram maior pureza quando comparadas às amostras da extração a partir do sobrenadante. Todas as amostras foram armazenadas a $-20^{\circ} \mathrm{C}$; duas destas que apresentaram maiores concentrações de DNA e maior grau de pureza, foram escolhidas para o teste dos oligonucleotídeos iniciadores e para a realização dos protocolos de clonagem.

Figura 14 - Células BF-2 infectadas por FV3-símile

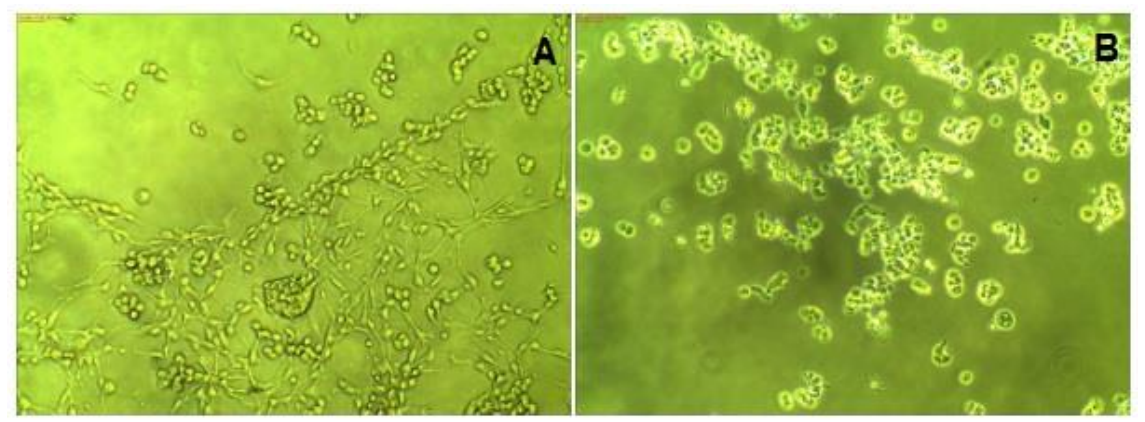

Legenda: A: Efeito citopático, após 24 h da infecção, B: Células BF-2 mortas, após 48 horas da infecção. Aumento de 100x. Fonte: Própria autoria. 


\subsection{Amplificação do gene MCP}

A confecção de um novo oligonucleotídeo no sentido reverse foi necessária para atender a uma especificação do Kit pET SUMO, em que se pede que o stop codon do gene esteja presente. Com o alinhamento das sequências do gene MCP do gênero Ranavirus depositadas no NCBI, com destaque a espécie tipo do FV3 e a sequência brasileira de FV3 depositada por Mazzoni et al. (2009). O oligonucleotídeo desenhado foi denominado MCP-RV-R2, 5' TTA CAA GAT TGG GAA TCC CAT 3', constituído de $21 \mathrm{pb}$, com $43,3 \%$ GC e temperatura de anelamento de $58^{\circ} \mathrm{C}$.

Algumas amostras foram submetidas a reação de PCR a fim de se testar a nova combinação de oligonucleotídeos para a amplificação do gene MCP. Foi obtido um amplicon do tamanho esperado para o gene MCP, com 1.392 pb, confirmando o sucesso da amplificação (Figura 15 - A). Em seguida, foi realizada uma nova reação para a utilização na ligação ao vetor pET SUMO; além disso, foi realizada a reação do Controle de PCR (Figura 15- B). As amostras foram imediatamente purificadas e quantificadas para realização da ligação.

Figura 15 - Amplificação do gene MCP do isolado FV3-símile e controles da reação de PCR

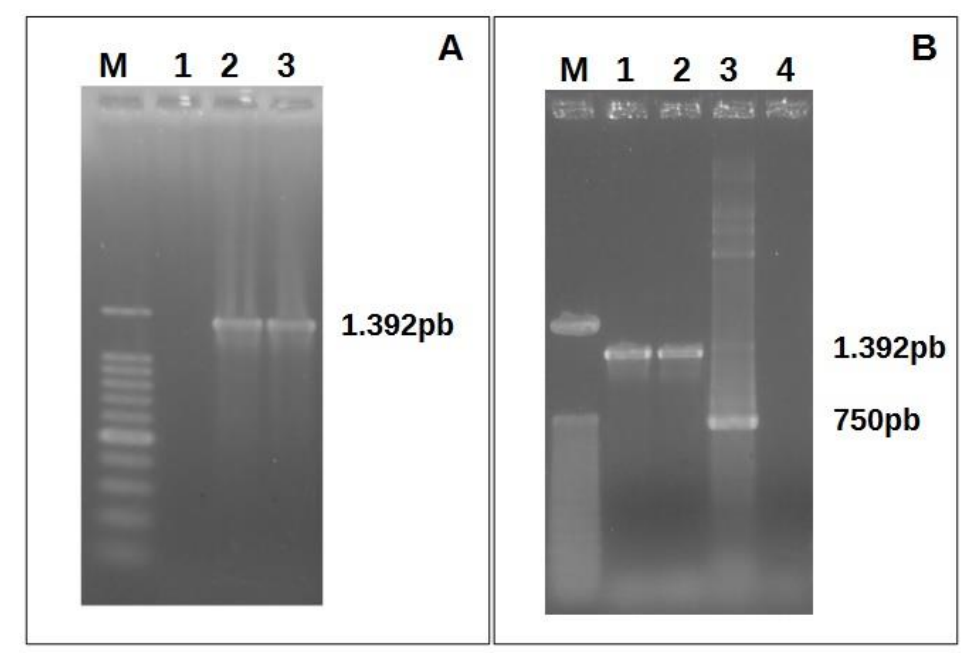

Legenda: Gel de agarose 1,5\%. A - M: Marcador de massa molecular (Ladder de 100pb, Promega), 1: $\mathrm{H}_{2} \mathrm{O}$ - Controle negativo da reação de PCR, 2 e 3: Amplicons do gene MCP, a partir do DNA viral de FV3-símile, fragmento com o tamanho esperado de $1.392 \mathrm{pb}$. B - M: Marcador de massa molecular (50pb DNA Ladder, Invitrogen), 1 e 2: Amplicons do gene MCP, do DNA viral de FV3-símile, fragmento de $1.392 \mathrm{pb}$, 3: Controle de PCR, fragmento esperado de 750pb, 4: $\mathrm{H}_{2} \mathrm{O}$ - Controle negativo da reação de PCR. Fonte: Própria autoria. 


\subsection{Clonagem do gene MCP em E. coli}

\subsubsection{Ligação e transformação na linhagem OneShot ${ }^{\circledR} \operatorname{Mach}^{\mathrm{TM}}-\mathrm{T} 1^{\mathrm{R}}$}

Para uma ligação mais eficiente foi utilizada a razão de $1 / 1$ de vetor $\mathrm{pET}$ SUMO e inserto, sendo os microtubos denominados: tubo L - ligação do gene MCP e tubo C - ligação do Controle de PCR. No dia seguinte, após 18 horas de incubação os vetores recombinantes $\mathrm{pET}$ SUMO/MCP e Controle de PCR foram inseridos por choque

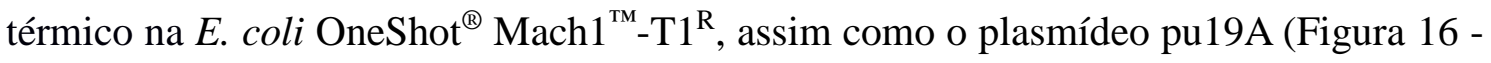
A).

Estas células transformadas foram plaqueadas em duplicada e incubadas overnight. O vetor pET SUMO não provoca crescimento diferencial de coloração como alguns vetores convencionais, portanto, todas as colônias são brancas (Figura 16). O crescimento nas placas de células transformadas com pET SUMO/MCP ( 100 colônias) foi semelhante ao crescimento do Controle de Transformação com o plasmídeo pu19A ( 100 colônias) demonstrando que as células estavam realmente competentes e a transformação foi eficiente. O Controle de PCR apresentou um crescimento maior que as demais placas (acima de 250 colônias), possivelmente em decorrência de uma ligação mais eficiente com o vetor, uma vez que o fragmento controle é menor que o gene MCP clonado.

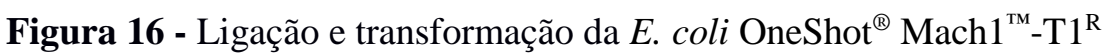
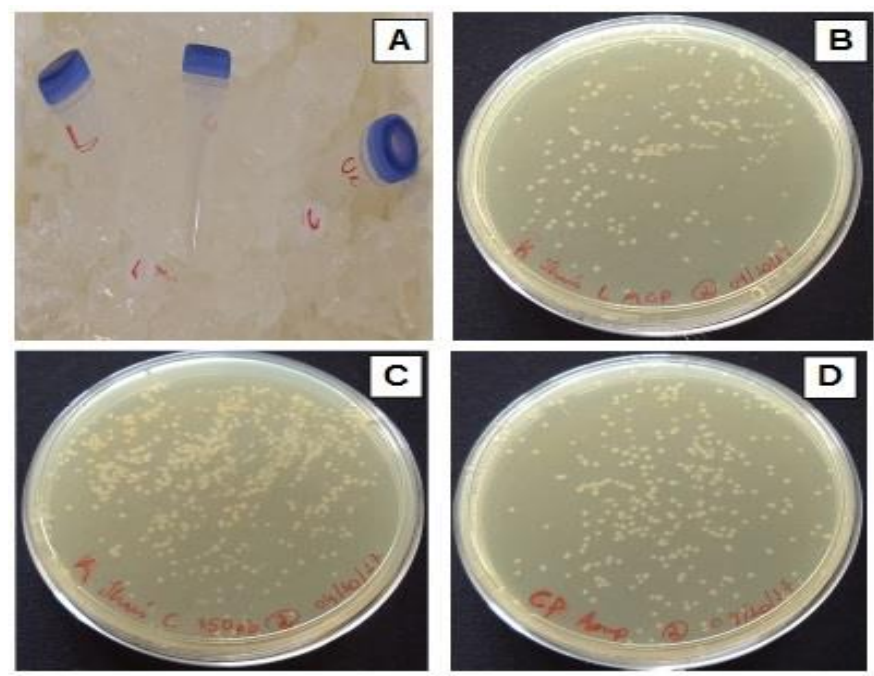

Legenda: A: Incubação em gelo, tubos de $0,2 \mathrm{~mL}$ contendo a reação de ligação e tubos (tampa azul) com as células quimicamente competentes; B: Placa com colônias da transformação com pET SUMO/MCP; C: Placa com colônias da transformação com Controle de PCR; D: Placa com colônias do Controle de transformação, plasmídeo pu19A. Fonte: Própria autoria. 
5.3.2 Análise dos clones recombinantes e dedução de aminoácidos do gene MCP

Foi realizado o repique de 40 colônias isoladas das placas pET SUMO/MCP, 20 colônias do Controle de PCR e 10 colônias do Controle de Transformação. Conforme sugerido pelo fabricante do kit Champion ${ }^{\mathrm{TM}}$ pET SUMO Protein Expression System, foram realizadas minipreps de apenas 10 clones da transformação com pET SUMO/MCP e dois clones do Controle de PCR; as demais colônias repicadas foram armazenadas com a adição de glicerol em $-20^{\circ} \mathrm{C}$ por garantia caso as colônias selecionadas não contivessem o gene clonado.

Foi realizada à amplificação por PCR do gene MCP com o DNA plasmidial dos 10 clones da transformação com pET SUMO/MCP e de dois clones do Controle de PCR. Dos clones recombinantes, $90 \%$ continham o gene MCP, demonstrando que a clonagem foi satisfatória, o gene completo estava inserido e o vetor era realmente recombinante pET SUMO/MCP (Figura 17). A eficiência do Controle de PCR foi de $100 \%$, ou seja, os dois clones recombinantes analisados apresentaram o fragmento de $750 \mathrm{pb}$ esperado.

Figura 17 - Verificação da presença do gene MCP no vetor recombinante

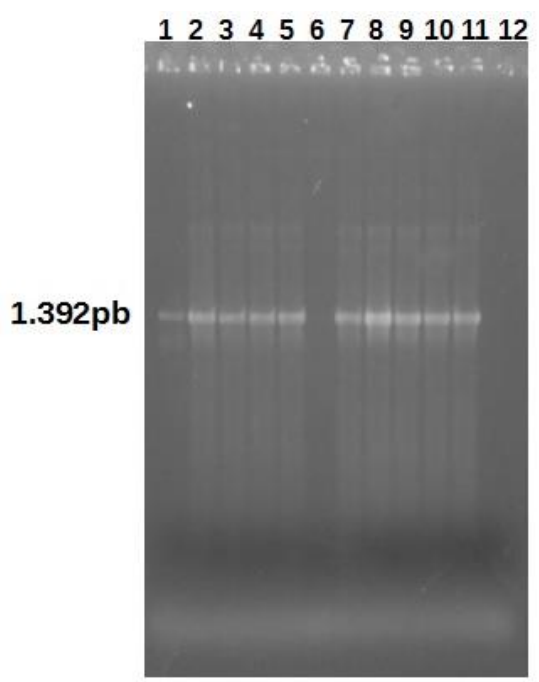

Legenda: Gel de agarose 1,5\%. 1: Controle positivo - amplicon do gene MCP, a partir do DNA viral de FV3-símile, 2 a 11: Amostras de dez clones, DNA plasmidial, com amplicons de tamanho esperado para o gene MCP inserido no vetor pET SUMO, onde apenas o poço 6 não apresentou amplificação, portanto, sem a presença do inserto, 12: $\mathrm{H}_{2} \mathrm{O}$ - Controle negativo da reação de PCR. Fonte: Própria autoria. 
Os nove clones recombinantes pET SUMO/MCP foram submetidos a reação de PCR com os oligonucleotídeos do vetor pET SUMO (item 4.3.2), todas as amostras apresentaram amplicons positivos ao tamanho esperado para o fragmento $1.645 \mathrm{pb}$, do gene MCP mais as extremidades do vetor. Cinco destes clones, que após a purificação, apresentaram maior concentração e pureza foram submetidos ao sequenciamento para verificar se o gene MCP clonado estava inserido na posição correta de produção da proteína recombinante rMCP. Após a análise dos eletroferogramas do sequenciamento verificou-se que três clones pET SUMO/MCP continham o gene MCP logo após o SUMO com start codon (ATG), stop codon (TAA) e sem a presença de qualquer mutação ou erro que alterasse o quadro de leitura da proteína (Figura 18).

Figura 18 - Sequência de nucleotídeos de um dos clones evidenciando a inserção do gene MCP na posição correta de leitura e expressão da proteína fusionada
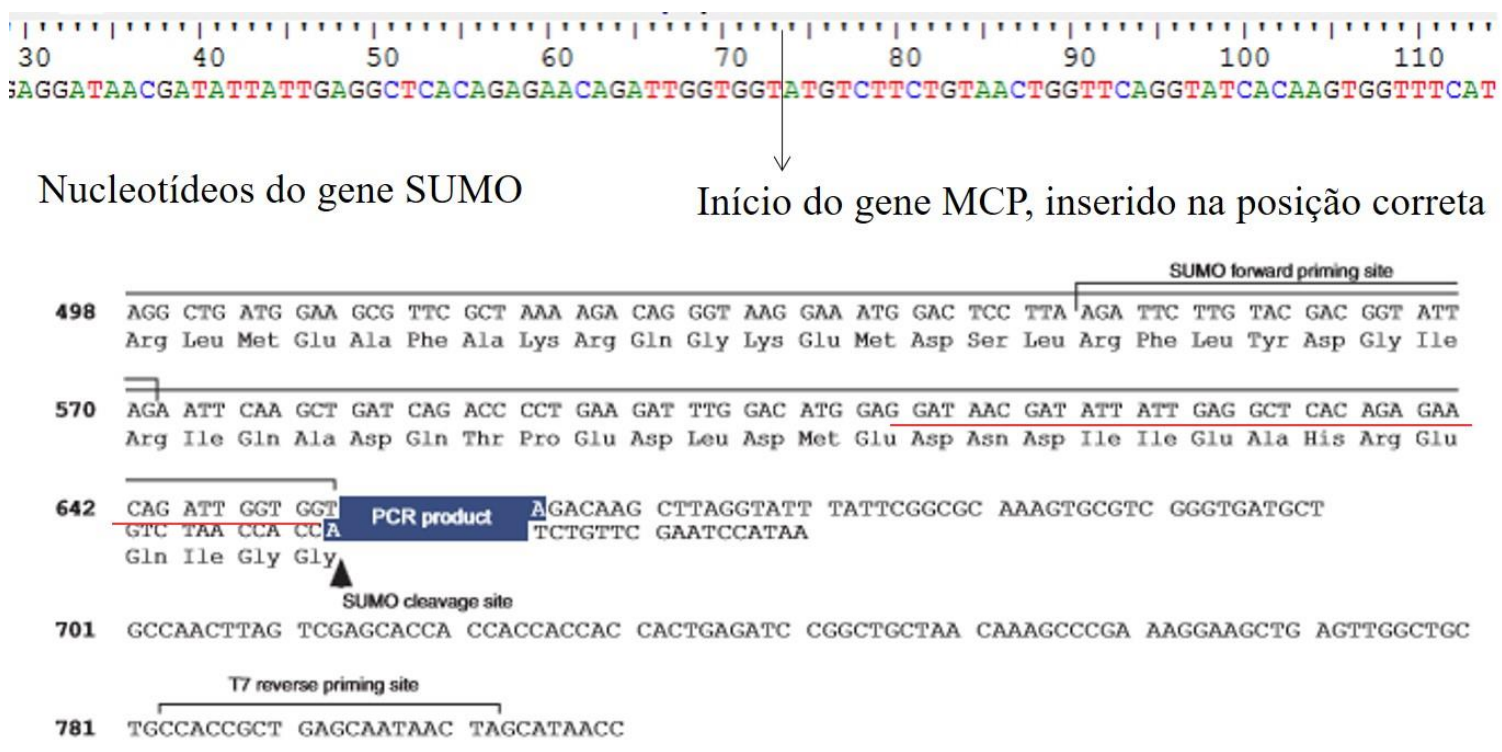

Legenda: Porção do sequenciamento no sentido do SUMO Forward no programa BioEdit. Na seta, o códon ATG de início do gene MCP. Mapa do vetor pET SUMO destacando-se em vermelho os nucleotídeos do gene SUMO (Manual part no. 25-0709 - MAN0000440). Fonte: Própria autoria.

A sequência nucleotídica do gene MCP foi depositada no GenBank, disponível com o número de acesso MH01657. Quando realizado o blast dos nucleotídeos o FV3-símile apresentou 99\% de homologia com a espécie tipo FV3 (AY 548484.1). A partir dos nucleotídeos do gene de interesse a sequência de 463 
aminoácidos do FV3-símile foi deduzida e comparada a sequências deduzidas do MCP desete espécies do gênero Ranavirus e do FV3 depositada por Mazzoni et al. (2009) (Figura 19).

Destacam-se três variações em relação aos demais FV3 analisados, nos aminoácidos 98, 99 e 216 que estão localizados no domínio N-terminal da proteína. No aa98 (292pb), ocorre a alteração de uma Glicina (G - GGA), compartilhada entre os demais Ranavirus analisados(com exceção Santee-Cooper ranavirus), para Arginina ( $\mathrm{R}$ - AGA) no FV3-símile; entretanto, por se tratar de um mesmo grupo funcional, R-polar não carregado (hidrofílico), a substituição é conservativa. No aa99 (295pb), o Ácido Aspártico (D - GAC) é substituído por Ácido Glutâmico (E - GAA) no FV3-símile, grupo carboxilato, R-polar carregado negativamente; portanto, substituição conservativa. Por fim, no aa216 (646pb), verifica-se a mudança de uma Histidina (H CAC), em dois outros FV3, para Glutamina (Q - CAG), diferentemente do FV3-símile (H), sendo que histidina é R-polar carregado positivamente e glutamina é R-polar não carregado, portanto substituição não conservativa no caso dos FV3; os demais Ranavirus apresentam Glutamina nesta posição. 
Figura 19 - Alinhamento entre as sequências deduzidas de aminoácidos do gene MCP

continuação

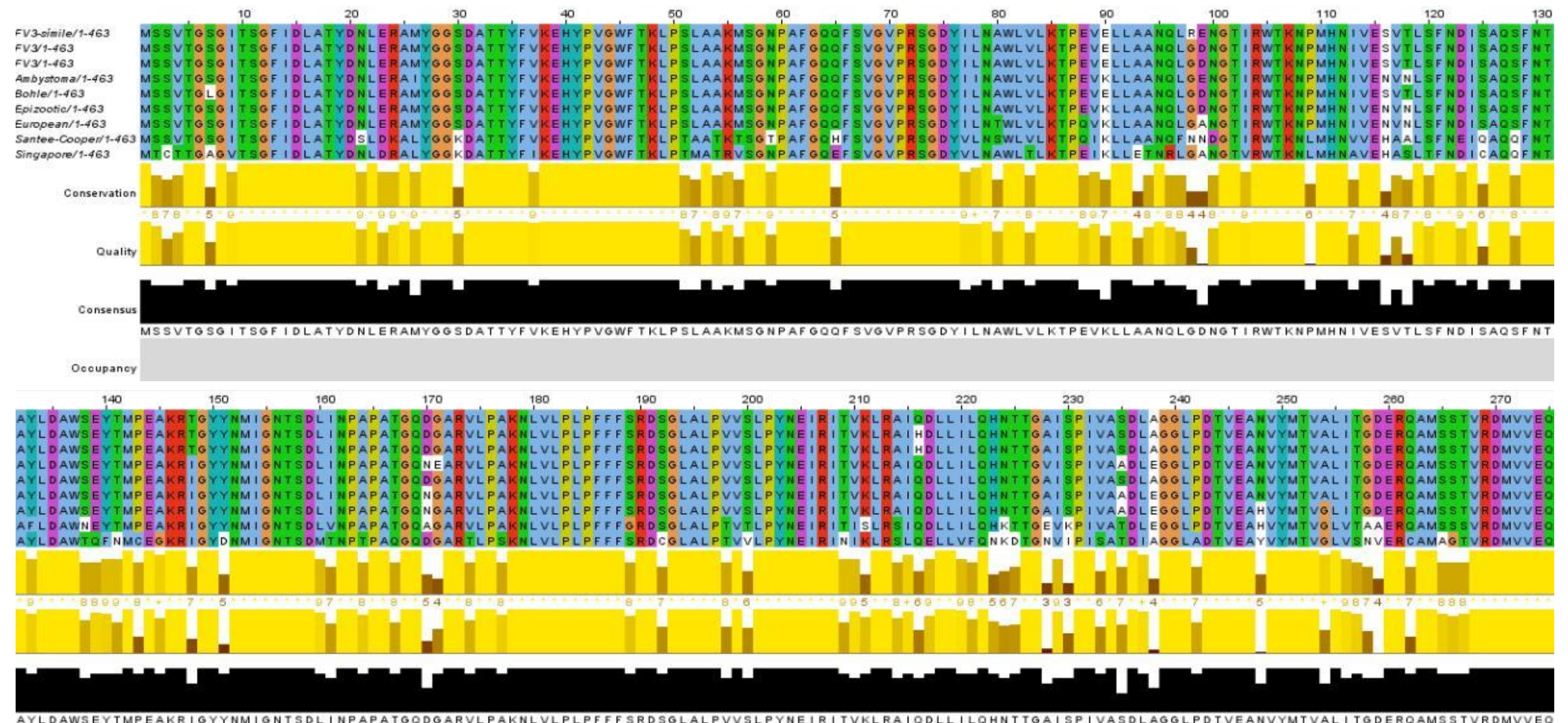

AYLDAWSEYTMPEAKRIGYYNMIONTSDLINPAPATGQDGARVLPAKNLVLPLPFFF SRDSGLALPVVSLPYNEIRITVKLRA ODLLILQHNT TGAISPIVASDLAGGLPDTVEANVYMTVALITGDERQAMSSTVRDMVVEO 
Figura 19 - Alinhamento entre as sequências deduzidas de aminoácidos do gene MCP

conclusão

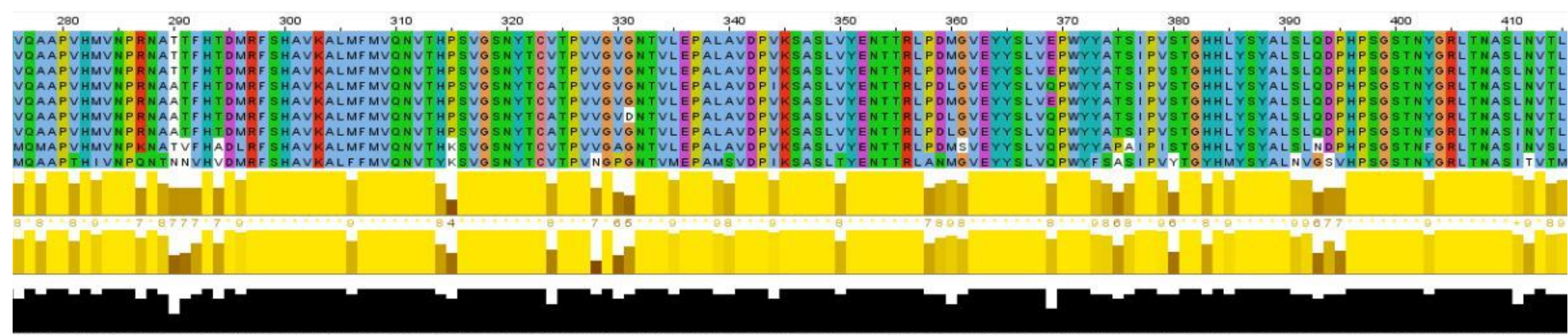
(1)

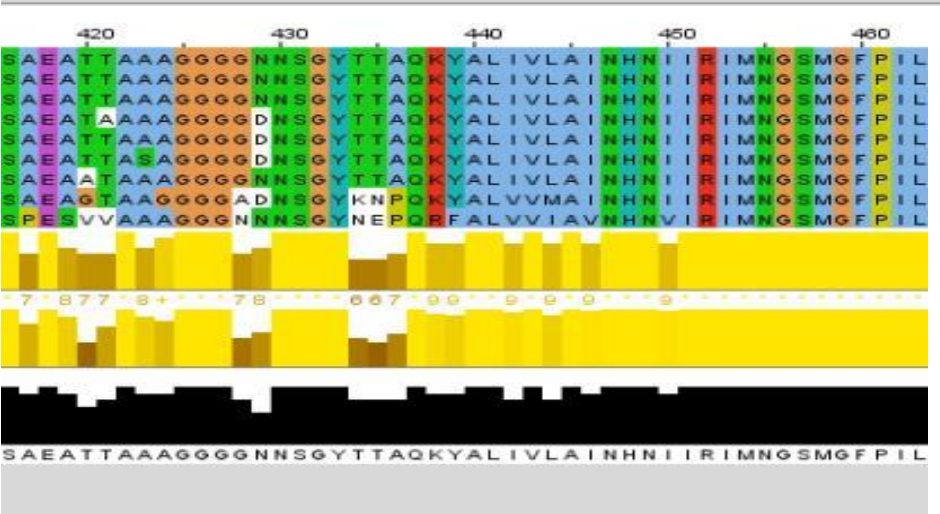

Legenda: O histograma Conservation reflete a conservação das propriedades físico-químicas dos aminoácidos e indica resíduos completamente conservados com um asterisco amarelo, sendo as posições menos conservadas mostradas em cores mais escuras. O histograma de qualidade de anotação Quality reflete a probabilidade de se observar uma mutação numa coluna qualquer do alinhamento baseada nos escores da matriz BLOSUM62 entre os resíduos mutados e o conservado. O histograma Consensus reflete a porcentagem do resíduo modal por coluna. Ordem e número de acesso: FV3-símile, FV3 (AY548484.1), FV3 (DQ897669.1) Mazzoni et al. (2009), Ambystoma tigrinum virus (AY150217.1), Bohle iridovirus (AY187046.1), Epizootic haematopoietic necrosis virus (FJ433873.1), European catfish virus (KT989884.1), Santee-Cooper ranavirus (KU507317.1) e Singapore grouper iridovirus (AY521625.1). Fonte: Própria autoria. 


\subsection{Análise da expressão com o vetor pET-SUMO da proteína rMCP por SDS- PAGE e WB}

Dois clones pET SUMO/MCP, 4 e 9, foram selecionados para a transformação na linhagem BL21(DE3) OneShot ${ }^{\circledR}$. Foram utilizados $5 \mathrm{ng} / \mu \mathrm{L}$ de DNA plasmidial recombinante pET SUMO/MCP para cada tubo com $50 \mu \mathrm{L}$ de células competentes e 10ng/ $\mu \mathrm{L}$ para o controle positivo $\mathrm{pET}$ SUMO/CAT. Após o choque térmico, as células transformadas foram crescidas em meio S.O.C. e na sequência em meio LB, iniciando-se os pré-inóculos dos pilotos de expressão realizados.

Como a cinética de produção de proteínas heterólogas está sujeita a fatores como tamanho e estrutura da proteína, solubilidade e transporte, a expressão da proteína rMCP foi realizada em três temperaturas, em diversas concentrações de indução com IPTG e sem a indução de IPTG. Esperava-se obter uma proteína de aproximadamente 63 $\mathrm{kDa}$, uma vez que a proteína $\mathrm{MCP}$ apresenta $50 \mathrm{kDa}$ e a proteína de fusão SUMO aproximadamente $13 \mathrm{kDa}$. Foi possível verificar esta produção da proteína recombinante por SDS-PAGE, identificada a partir de 4 horas de indução nas temperaturas testadas, sendo que a $37^{\circ} \mathrm{C}$ apenas na fração insolúvel - poços 13 e 14 (Figura 20). Por outro lado, o piloto de expressão a $22^{\circ} \mathrm{C}$ foi testado sem lise celular, a proteína recombinante pode ser observada no SDS-PAGE em todas as concentrações de IPTG em maior quantidade (t4) - poços 4, 5 e 6 - ou menor (t24) (Figura 21), a expressão em $18^{\circ} \mathrm{C}$ não diferiu dos resultados observados em $22^{\circ} \mathrm{C}$. Os controles utilizados demonstram que a BL21(DE3) OneShot ${ }^{\circledR}$ sem o vetor não expressa a proteína de $63 \mathrm{kDa}$ que o vetor pET SUMO/MCP expressa e o controle de expressão CAT produziu a proteína esperada de $39 \mathrm{kDa}$ em sua forma solúvel (Figura 21). 
Figura 20 - Caracterização por SDS-PAGE da proteína rMCP da expressão a $37^{\circ} \mathrm{C}$

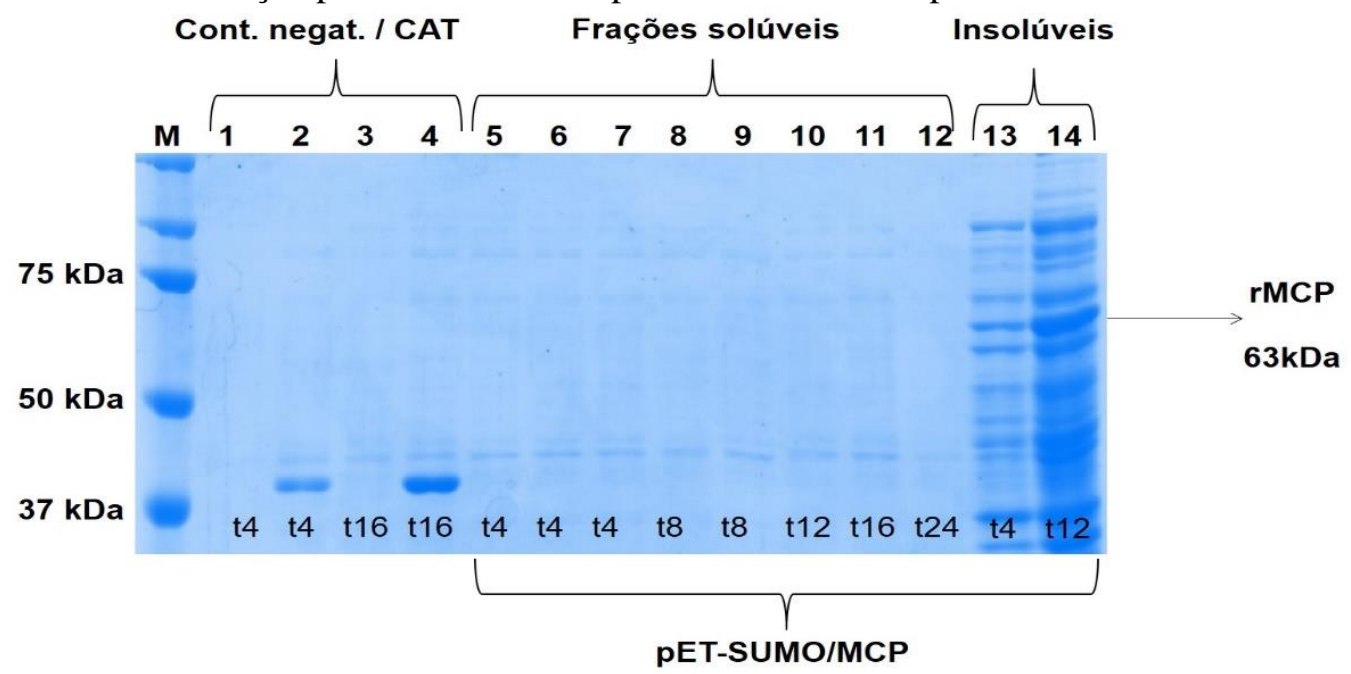

Legenda: Gel de poliacrilamida 10\% evidenciando a expressão do controle positivo e a rMCP. M: marcador de massa molecular (Precision Plus Protein ${ }^{\mathrm{TM}}$ Kaleidoscope ${ }^{\mathrm{TM}}$, Bio-Rad), 1 a 12 frações solúveis pós lise celular, sendo 1: Controle negativo, BL21(DE3) sem vetor no intervalo de tempo de 4 horas - t4 a 1mM de IPTG, 2: Controle positivo CAT t4 a 1mM, 3: BL21(DE3) t16 a 1mM, 4: CAT t16 a 1mM, 5: pET SUMO/MCP t4 a 1mM, 6: pET SUMO/MCP t4 a 0,5mM, 7: pET SUMO/MCP t4 a 1,5mM, 8: pET SUMO/MCP t8 a 1mM, 9: pET SUMO/MCP t8 a 0,5mM, 10: pET SUMO/MCP t12 a 1mM, 11: pET SUMO/MCP t16 a 1mM, 12: pET SUMO/MCP t24 a 1mM; 13 e 14 frações insolúveis, sendo 13: pET SUMO/MCP t4 a 1mM e 14: pET SUMO/MCP t12 a 1mM. A seta indica a expressão esperada na região de $63 \mathrm{kDa}$. Fonte: Própria autoria.

Figura 21 -Caracterização por SDS-PAGE da proteína rMCPda expressão a $22^{\circ} \mathrm{C}$

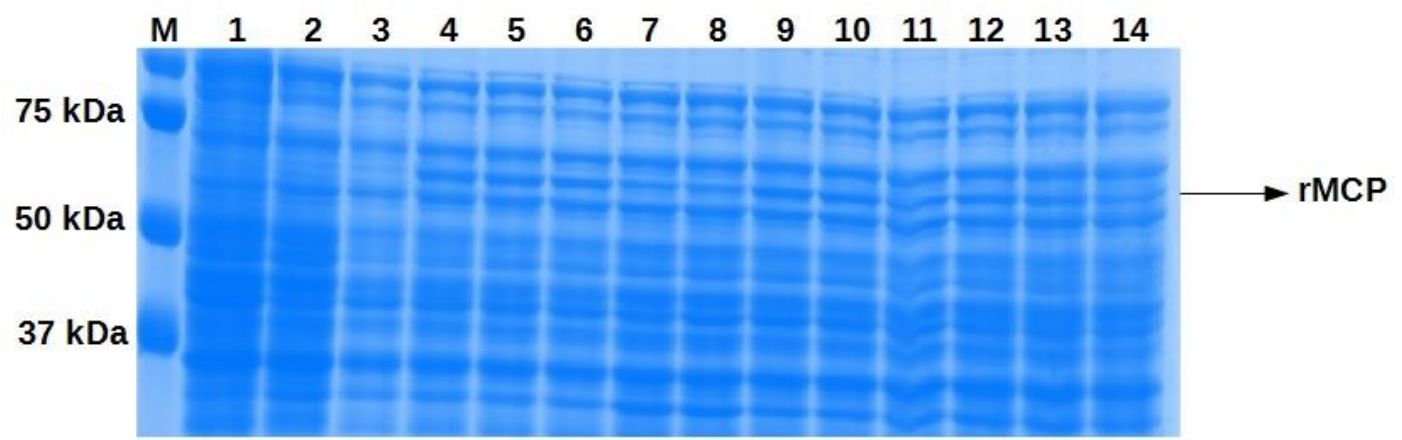

Legenda: Gel de poliacrilamida 10\% evidenciando a expressão da proteína rMCP. M: marcador de massa molecular (Precision Plus Protein ${ }^{\mathrm{TM}}$ Kaleidoscope ${ }^{\mathrm{TM}}$, Bio-Rad), 1 a 14 extrato proteico total da indução, sendo 1: Controle negativo, BL21(DE3) sem vetor no intervalo de tempo de 4 horas - $\mathrm{t} 4 \mathrm{a}$ 1mM de IPTG, 2: pET SUMO/MCP t16 sem indução com IPTG, 3: pET SUMO/MCP t0 a 0,5mM de IPTG, 4: pET SUMO/MCP t4 a 1mM, 5: pET SUMO/MCP t4 a 0,5mM, 6: pET SUMO/MCP t4 a 0,1mM, 7: pET SUMO/MCP t24 a 1mM, 8: pET SUMO/MCP t24 a 0,5mM, 9: pET SUMO/MCP t12 a 1mM, 10: pET SUMO/MCP t12 a 0,5mM, 11: pET SUMO/MCP t12 a 0,1mM; 12: pET SUMO/MCP t16 a 1mM, 13: pET SUMO/MCP t16 a 0,5mM e 14: pET SUMO/MCP t16 a 0,1 $\mathrm{mM}$. A seta indica a expressão esperada na região de 63 $\mathrm{kDa}$. Fonte: Própria autoria. 
Além da análise por SDS-PAGE, o WB utilizando a marcação da His-tag, demonstrou a expressão da proteína rMCP mesmo antes da purificação. Foi possível identificar uma grande quantidade da rMCP nas frações insolúveis, principalmente na expressão a $37^{\circ} \mathrm{C}$, confirmando que a expressão com o vetor pET-SUMO não facilitou a solubilização da proteína recombinante (Figura 22).

Figura 22 - Caracterização por WB da proteína rMCP da expressão a $37^{\circ} \mathrm{C}$ e $22^{\circ} \mathrm{C}$

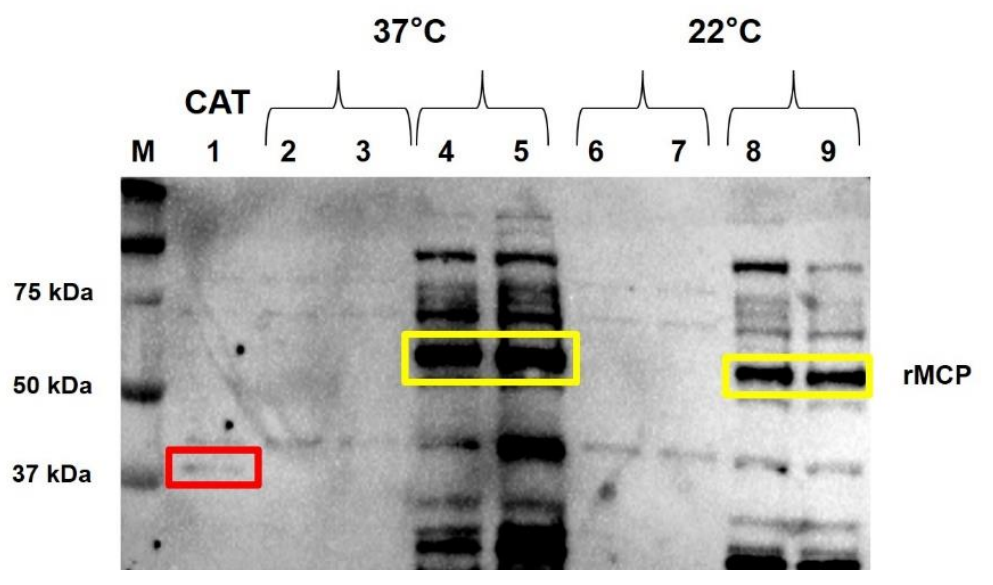

Legenda: Membrana de WB utilizando-se o anticorpo primário anti-HisTag. M: marcador de massa molecular (Precision Plus Protein ${ }^{\mathrm{TM}}$ Kaleidoscope ${ }^{\mathrm{TM}}$, Bio-Rad), 1 a 5 piloto de expressão a $37^{\circ} \mathrm{C}$ induzidos a $1 \mathrm{mM}$, sendo 1 a 3 fração solúvel, 1: CAT t4 evidenciando a proteína de 39kDa, 2: pET SUMO/MCP t4 e 3: pET SUMO/MCP t8, 4 e 5 frações insolúveis a t4 e t8 respectivamente, 6 a 9 piloto de expressão a $22^{\circ} \mathrm{C}$ induzidos a $1 \mathrm{mM}$, fração solúvel 6: pET SUMO/MCP t4 e 7: pET SUMO/MCP t8, 8 e 9 frações insolúveis a t4 e t8 respectivamente. As proteínas rMCP esperada de $63 \mathrm{kDa}$. Fonte: Própria autoria.

\subsection{Nova estratégia de clonagem e expressão do gene MCP}

Diante das dificuldades e baixa expressão da proteína rMCP com a utilização do kit Champion ${ }^{\mathrm{TM}}$ pET SUMO Protein Expression System, apesar do objetivo principal ter sido atingido inicialmente, optou-se por recomeçar todo o processo de produção da proteína recombinante (rMCP). Dessa forma, aplicando uma nova estratégia de clonagem com vetores que possuem múltiplos sítios de clonagem, ou seja, locais de clivagem por enzimas de restrição, e também, utilizando outra linhagem celular para a expressão, a fim de alcançar a superexpressão (over-expression).

Inicialmente foram avaliadas quais enzimas de restrição poderiam ser usadas para o gene MCP, para que estas enzimas não cortassem o gene de interesse. 
Além disso, foram verificadas se as mesmas poderiam ser empregadas no vetor de expressão. Foram escolhidas as enzimas NadI (sentido forward) e EcoRI (sentido reverse).

\subsubsection{Amplificação e purificação do gene MCP}

A amostra de DNA viral de FV3-símile foi submetida à reação de PCR com os novos oligonucleotídeo desenhados (Pet28MCP-F e Pet28MCP-R) para a amplificação do gene MCP com as extremidades referentes às enzimas de restrição escolhidas. Foi obtido um amplicon do tamanho esperado de 1.398 pb. Em seguida, foi realizada a purificação do gel de agarose e quantificação do fragmento amplificado (média de $40 \mathrm{ng} / \mu \mathrm{L}$ ) (Figura 23).

Figura 23 - Amplificação do gene MCP de FV3-símile utilizando Pet28MCP-F e Pet28MCP-F

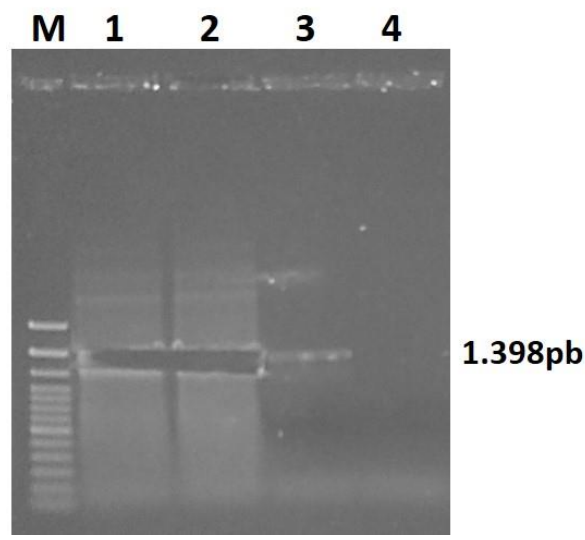

Legenda: Gel de agarose 1,5\%. M: Marcador de massa molecular (100 pb DNA Ladder, Invitrogen), 1 a 3: amostras de DNA viral de FV3-símile amplificadas e evidenciando o amplicon excisado para a purificação, 4: H2O - Controle negativo da reação de PCR. Fonte: Própria autoria.

\subsubsection{Clonagem no vetor nos vetores pGEM $^{\circledR}-\mathrm{T}$ e pET28a (+) DNA}

5.5.2.1 Ligação e transformação no vetor pGEM $^{\circledR}$-T

A sequência do gene MCP amplificada e purificada foi clonada no vetor de clonagem pGEM $^{\circledR}-\mathrm{T}$ pelo sistema TA. Este vetor foi transformado em células 
competentes DH5a para a multiplicação do vetor com o inserto. A eficiência da ligação e transformação ficou dentro do esperado para o vetor a pGEM $^{\circledR}$-T, onde, das 70 colônias crescidas na placa, $80 \%$ eram colônias brancas, ou seja, possuíam o inserto $\left(\right.$ pGEM $\left.^{\circledR}-\mathrm{T} / \mathrm{MCP}\right)$ (Figura 24 - A).

Foram realizadas as minipreps de quatro colônias pGEM ${ }^{\circledR}-\mathrm{T} / \mathrm{MCP}$, que apresentaram em média $320 \mathrm{ng} / \mu \mathrm{L}$ de DNA plasmidial. Além disso, também foi extraído DNA do vetor pET28a(+) que estava em células DH5 $\alpha$, obtendo-se $100 \mathrm{ng} / \mu \mathrm{L}$.

5.5.2.2 Digestão enzimática, ligação e transformação no vetor de expressão pET28a(+)

Os plasmídeos pGEM $^{\circledR}$-T/MCP e pET28a(+) foram digeridos com as enzimas de restrição escolhidas, NdeI e EcoRI. Depois, todas as amostras da digestão do pGEM $^{\circledR}$-T/MCP foram aplicadas em um mesmo poço do gel de agarose. Foram observados, como esperado, dois produtos da digestão com as enzimas NdeI e EcoRI, um fragmento de aproximadamente $3 \mathrm{Kbp}$ e outro de $1.400 \mathrm{pb}$, correspondendo ao vetor linearizado e ao fragmento do tamanho do gene MCP, respectivamente. Adicionalmente, foi recuperado o vetor pET28a(+) linearizado $(\sim 5.3 \mathrm{Kbp})$, seguindo-se a purificação e a quantificação do DNA.

Devido à baixa eficiência de recuperação, o DNA com os sítios de ligação definidos pelas enzimas, de $14 \mathrm{ng} / \mu \mathrm{L}$ para o fragmento do gene MCP e $3 \mathrm{ng} / \mu \mathrm{L}$ para o vetor pET28a(+) linearizado, a reação de ligação para a subclonagem precisou ser ajustada (item 4.4.3). Entretanto, após a transformação em células competentes DH5 $\alpha$, observou-se uma grande eficiência na subclonagem que originou o plasmídeo de expressão pET28a/MCP (Figura 24 - B).

Figura 24 - Placas de cultivo das colônias de DH5a
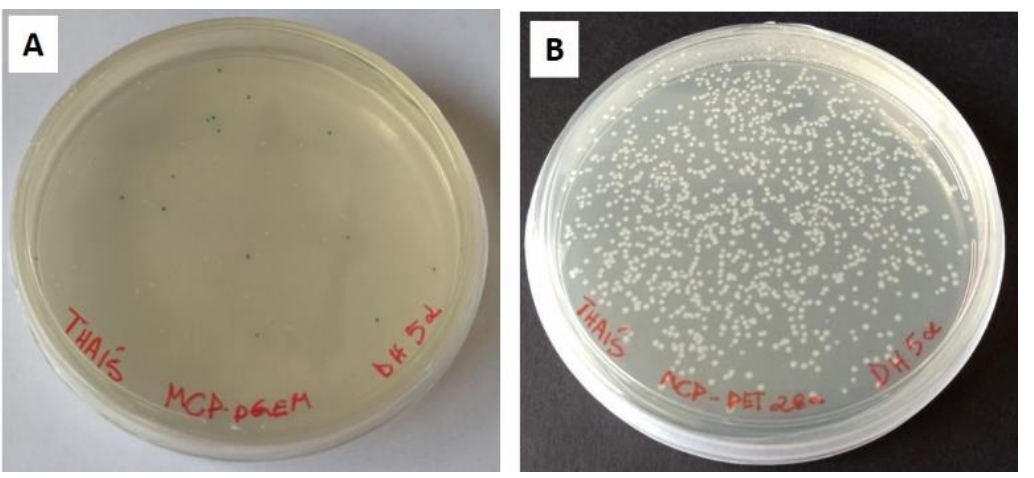

Legenda: A: colônias azuis (14) e brancas (56) da clonagem com o vetor pGEM ${ }^{\circledR}$-T. B: colônias resultantes da transformação das células competentes com o vetor pET28a/MCP. Fonte: Própria autoria. 
Como o vetor pET28a(+) não apresenta crescimento diferencial de coloração das colônias que apresentam o inserto das que não apresentam, foi realizada a verificação da construção do plasmídeo de expressão pET28a/MCP via PCR. Portanto, seis colônias foram submetidas à extração plasmidial (Figura 25). Ademais, os plasmídeos pET28a/MCP foram recuperados para a transformação nas células competentes responsáveis pela expressão. A quantificação de DNA plasmidial foi em média $80 \mathrm{ng} / \mu \mathrm{L}$.

Figura 25 - Verificação da construção pET28a/MCP

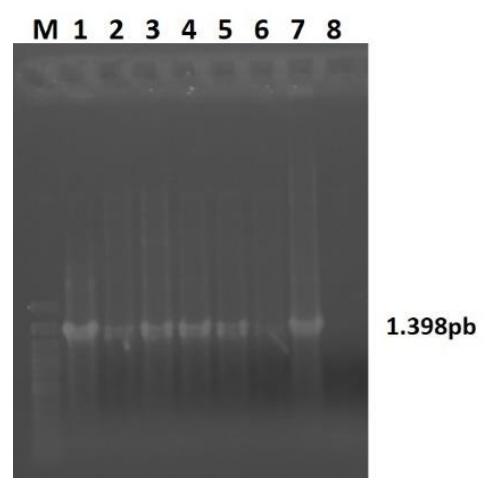

Legenda: Gel de agarose 1,5\%. M: Marcador de massa molecular (100 pb DNA Ladder, Invitrogen), 1: DNA viral FV3-símile - controle positivo; 2 a 7: amostras de DNA plasmidial pET28a/MCP, 8: H2O - Controle negativo da reação de PCR. Fonte: Própria autoria.

5.5.2.3 Transformação em duas linhagens de E. coli e expressão da proteína rMCP

Após a propagação do plasmídeo de expressão pET28a/MCP em células de clonagem (DH5 $)$, as duas linhagens celulares quimicamente competentes e capazes de realizar a expressão de proteínas recombinantes, a linhagem BL21(DE3) OneShot ${ }^{\circledR}$ e a nova linhagem Rosetta ${ }^{\mathrm{TM}}(\mathrm{DE} 3)$ foram transformadas com sucesso.

O piloto de expressão foi realizado a partir do pré-inóculo da transformação das duas linhagens, que ao atingirem a $\mathrm{DO}_{600}$ superior a 0,6 foram induzidas com $1 \mathrm{mM}$ de IPTG, para indução direta do gene T7 RNA polimerase no DNA genômico da E. coli (região DE3) e, este por seguinte, ativar a região promotora T7 do vetor pET28a/MCP e expressar a proteína rMCP. 


\subsection{Análise da nova expressão proteína rMCP}

\subsubsection{SDS-PAGE e WB}

O piloto de expressão foi verificado através de SDS-PAGE e WB. Primeiramente, a proteína $\mathrm{rMCP}$ produzida foi avaliada nas frações solúveis e insolúveis das duas linhagens utilizadas e para identificar o melhor tempo de overexpression (Figura 24). Podemos constatar que a proteína rMCP foi expressa com o vetor $\mathrm{pET} 28 \mathrm{a} / \mathrm{MCP}$ nas duas linhagens, mais uma vez de forma mais expressiva em sua forma insolúvel. Na E. coli BL21(DE3) OneShot ${ }^{\circledR}$ foi expressa de forma nitidamente basal, sendo a proteína de peso molecular de aproximadamente $35 \mathrm{kDa}$, tamanho que não seria esperado para o MCP, expressa de maneira mais evidente. Já a linhagem de $E$. coli Rosetta $^{\mathrm{TM}}(\mathrm{DE} 3)$, uma grande expressão da proteína rMCP pode ser vista a partir de 2 horas, atingindo o ponto máximo em 4 horas após a indução com IPTG (Figura 26 A).

Com a realização do $\mathrm{WB}$, em espelho do SDS-PAGE, utilizando-se o anticorpo anti-Iridovírus, foi possível confirmar a produção da proteína rMCP de $50 \mathrm{kDa}$, bem como fragmentos de peso molecular menores, principalmente de $35 \mathrm{kDa}$ na expressão por BL21(DE3). Na expressão com a Rosetta ${ }^{\mathrm{TM}}(\mathrm{DE} 3)$, podemos verificar que, com a expressão basal da T7 RNA polimerase, no t0 já é possível observar esta proteína de peso molecular menor tanto na porção solúvel quanto na insolúvel, e que só com o passar do tempo de indução, a proteína com o peso molecular esperado para o gene MCP (50kDa) é produzida em maior quantidade (Figura 26 - B). 
Figura 26 - Caracterização por SDS-PAGE e WB da proteína rMCP no piloto de expressão com o vetor $\mathrm{pET}-28 \mathrm{a} / \mathrm{MCP}$ nas duas linhagens de expressão

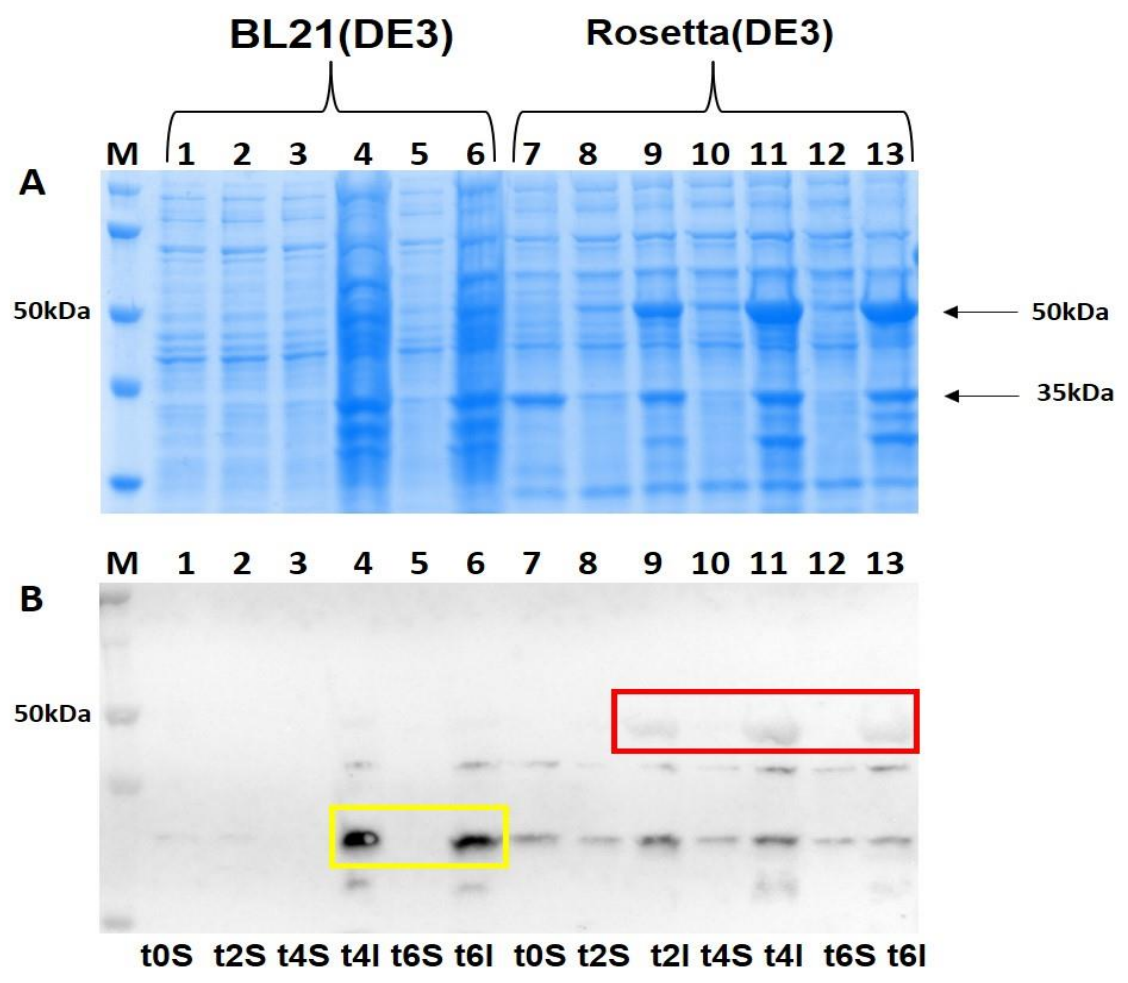

Legenda: A - Gel de poliacrilamida $10 \%$ evidenciando a expressão da proteína rMCP, M: marcador de massa molecular (Precision Plus Protein ${ }^{\mathrm{TM}}$ Kaleidoscope $^{\mathrm{TM}}$, Bio-Rad), 1 a 6 extrato proteico da indução da expressão em células BL21(DE3), porção solúvel (S) e porção insolúvel (I), sendo: 1- t0S, 2- t2S, 3- t4S, 4- t4I, 5- t6S, 6- t6I ; 7 a 13 extrato proteico da indução da expressão em células RosettaTM(DE3), sendo: 7- t0S, 8- t2S, 9- t2I, 10- t4S, 11- t4I, 12-t6S, 13- t6I. B - espelho no WB utilizando-se o anticorpo anti-Iridovirus. Fonte: Própria autoria.

Estas outras proteínas que reagiram com o anticorpo primário anti-Iridovírus podem indicar uma possível expressão truncada da proteína $\mathrm{rMCP}$, a presença de transcritos incompletos, uma finalização da expressão antes de completar a leitura por ausência de códons, instabilidade do mRNA, ação proteolítica, alteração conformacional durante o processamento da proteína ou outro fator biológico na produção desta proteína recombinante. Estas são algumas das hipóteses. Entretanto, quando comparada à produção da proteína $\mathrm{rMCP}$ pelo pET-SUMO/MCP, a expressão em Rosetta ${ }^{\mathrm{TM}}(\mathrm{DE} 3)$ foi mais eficiente, produzindo uma maior quantidade de proteína rMCP de 50kDa em 4 horas de expressão. Portanto, a partir deste momento passou-se a utilizar apenas a expressão da proteína rMCP promovida pelo vetor $\mathrm{pET}$-SUMO/MCP em Rosetta ${ }^{\mathrm{TM}}(\mathrm{DE} 3)$. 


\subsubsection{Espectrofotometria de Massas}

A fim de compreender melhor a expressão da proteína rMCP, foi realizada a análise de espectrofotometria de massas com as amostras proteicas de maior expressão. Uma mesma amostra foi aplicada em três poços do gel de poliacrilamida para a recuperação das bandas, contendo as proteínas de peso molecular de 50 e 35kDa, produzidas pelo pET-SUMO/MCP em Rosetta ${ }^{\mathrm{TM}}(\mathrm{DE} 3)$ (Figura 27).

Figura 27 - Gel de poliacrilamida representando as bandas que foram excisadas para recuperação dos peptídeos e realização $\mathrm{LC}-\mathrm{MS}^{\mathrm{E}}$

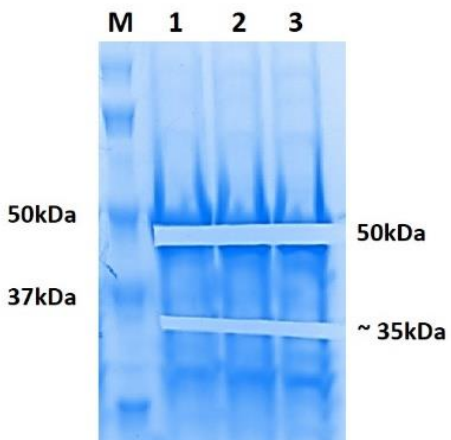

Legenda: M: marcador de massa molecular (Precision Plus Protein ${ }^{\mathrm{TM}}$ Kaleidoscope ${ }^{\mathrm{TM}}$, Bio$\mathrm{Rad}) ; 1$ a 3 amostras proteicas rMCP. Evidenciando as bandas recortadas do gel de poliacrilamida. Fonte: Própria autoria.

Os dados produzidos pela leitura no espectrômetro de massas Synapt G2 HDMS (Waters, EUA) para a proteína de $50 \mathrm{kDa}$ indicam que realmente se trata da proteína MCP. A análise apresentou uma cobertura de 92,22\% com 0\% de índice de falso positivo, confirmando o sucesso da expressão da proteína recombinante produzida no trabalho. Na figura 26, podem ser observado três aminoácidos iniciais pertencentes ao vetor pET28a(+), e também os últimos peptídeos da proteína, que são peptídeos únicos, o que indicaria que o gene foi expresso por completo. Os "gaps" encontrados no meio do sequenciamento possivelmente são em decorrência de uma limitação do método, pois no processo de digestão por tripsina e recuperação dos peptídeos alguns deles podem ter sido perdidos em algumas das etapas.

A análise do fragmento de $35 \mathrm{kDa}$ revelou que apesar de uma cobertura menor de $66,46 \%$ com $0 \%$ de índice de falso positivo, esta proteína também é a proteína rMCP. Podemos verificar que, no início, temos a presença dos aminoácidos do 
vetor, o que explicaria sua recuperação pela purificação His-tag. Além disso, podemos observar vários trechos da proteína, até bem próximo ao fim dos 463 aminoácidos, o que não indicaria que a expressão foi finalizada antes; por outro lado, a expressão pode ter sido truncada durante a leitura. No caso da proteína de $35 \mathrm{kDa}$, o número maior de gaps também pode ter sido uma falha do método, já que a cobertura foi mais baixa, indicando uma maior perda de peptídeos, mas também pode ser uma evidência clara de uma leitura descontínua do gene, gerando um transcrito menor (Figura 28).

Figura 28 - Representação do sequenciamento proteico realizado por espectrometria de massa

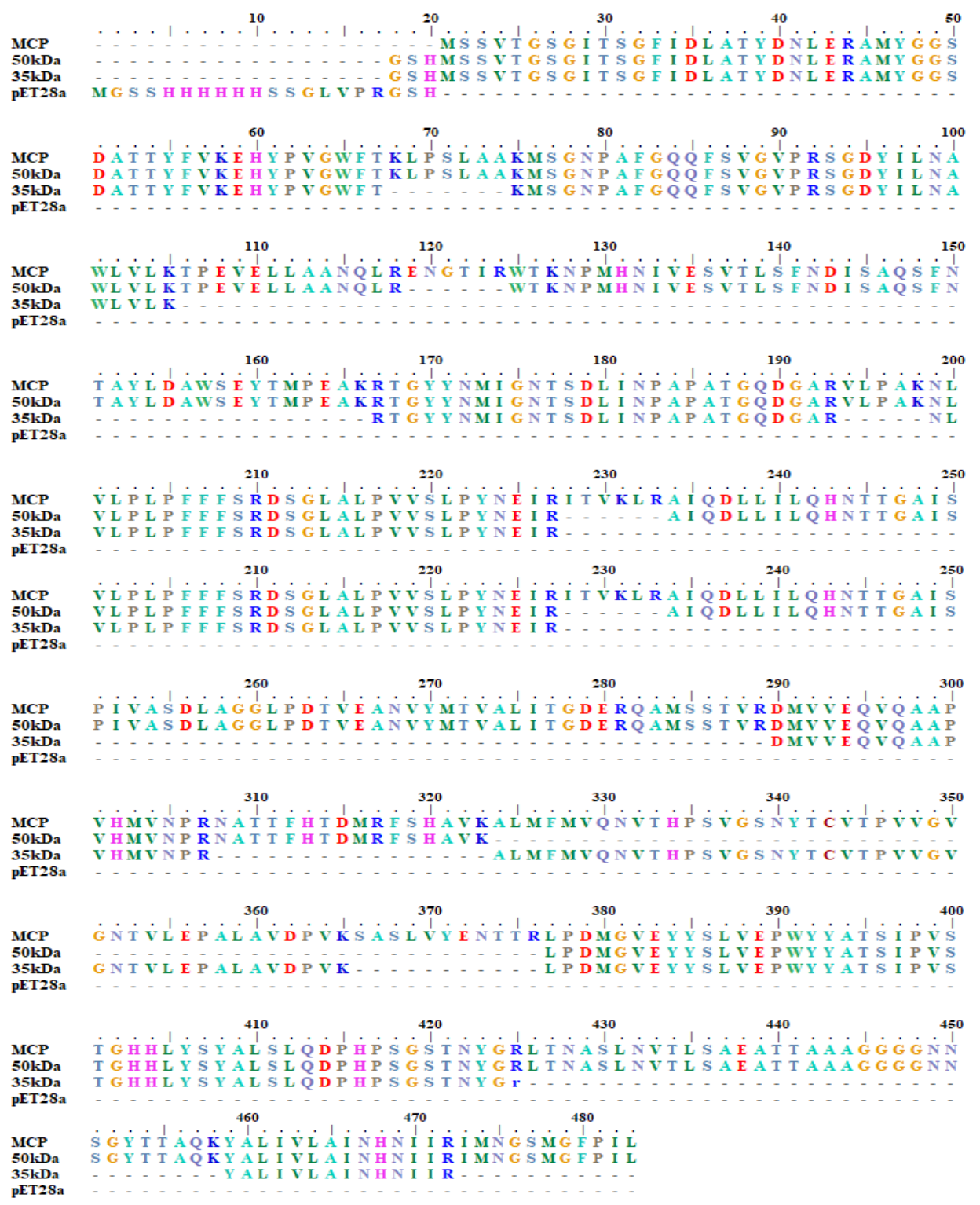

Legenda: MCP: proteínas do gene MCP do Ranavirus FV3-símile; 50kDa: proteína rMCP de peso molecular esperado; 35kDa: proteína rMCP de peso molecular menor; pET28a: região do vetor com a His-tag e os aminoácidos que precedem a expressão do gene alvo. Fonte: Própria autoria. 
A E. coli Rosetta $^{\mathrm{TM}}(\mathrm{DE} 3)$ é uma linhagem deficiente em protease, portanto, a hipótese de uma ação proteolítica poderia ser descartada. Além disso, esta linhagem possui uma suplementação de códons raros, o que explicaria uma maior eficiência na expressão com esta bactéria do que com a linhagem BL21(DE3). Uma vez que gene MCP possui muitos aminoácidos transcritos por códons raros (Tabela 5). Apesar de não ser possível identificar no sequenciamento proteico uma relação entre os gaps e estes códons, esta pode ser uma explicação para a produção de uma proteína rMCP de peso molecular menor, pois a metodologia empregada não utilizou técnicas de edição genômica e nem utilizou um gene sintetizado, o trabalho foi realizado com o gene MCP do FV3-símile em sua forma original.

Tabela 5 - Proporção de aminoácidos da proteína MCP do FV3-símile. Códons raros em E. coli e os observados no gene MCP

\begin{tabular}{cccc}
\hline Aminoácidos & Quantidade & Códons raros* & Encontrados no MCP \\
\hline Ala & 44 & & \\
Arg & 16 & AGA, AGG, CGA, CGG & 13: AGA ou AGG \\
Asn & 30 & & \\
Asp & 18 & UGG, UGC & 1: UGC \\
Cys & 1 & & \\
Gln & 13 & & \\
Glu & 17 & GGA, GGG & \\
Gly & 34 & AUA & 1 \\
His & 11 & CUA, CUC & \\
ILe & 22 & & \\
Leu & 42 & & \\
Lys & 11 & & 18 \\
Met & 16 & CCC, CCU, CCA \\
Phe & 14 & UCA, AGU, UCG, UCC & \\
Pro & 28 & ACA & \\
Ser & 38 & & 10 \\
Thr & 40 & & \\
Trp & 5 & & \\
Tyr & 22 & & \\
Val & 41 & & \\
& & & \\
\hline
\end{tabular}

Legenda: Destaque em verde claro os aminoácidos que possuem códons raros em E. coli. Aminoácidos em ordem alfabética. Quantidade em número absoluto de cada aminoácido encontrado no gene MCP. Códons raros em E. coli. Códons raros identificados no gene MCP. * Segundo: KANE, 1995; CHEM; TEXADA, 2006. Fonte: Própria autoria. 


\subsection{Purificação e quantificação da proteínarMCP}

Ao longo do trabalho, foram testados vários tampões de lise, a fim de se recuperar a proteína rMCP na porção solúvel, ou ao menos, que possibilitasse a purificação de uma forma mais eficiente. Foram utilizados reagentes como: fosfato de sódio, Tris, EDTA, NaCl, Imidazol, Tween 20, Triton X-100, Ureia, resumidamente. Além disso, foram testados a utilização de dois tipos de sonicador (banho e ponteira), congelamento rápido com nitrogênio ou $-80^{\circ} \mathrm{C}$ e descongelamento em banho maria.

Como o kit ProBond ${ }^{\mathrm{TM}}$ Purification System permite três condições de purificação, todas foram testadas com o pellet da expressão em larga escala: a purificação nativa, que permite trabalhar com proteínas solúveis (no sobrenadante, após a lise) e preservar a atividade da proteína; a purificação híbrida, quando a proteína for insolúvel (no pellet, após a lise) e for necessário preservar a atividade da proteína; e a purificação desnaturante em que a proteína é insolúvel e não depende da atividade proteica após a purificação. Por fim, a partir dos resultados observados nas purificações da rMCP expressa pelo vetor pET28a/MCP, o processo de purificação foi definido na condição desnaturante.

Apesar de não ser o processo de obtenção da proteína recombinante mais desejado para a produção de anticorpos policlonais, foi com a purificação desnaturante que se obteve a proteína rMCP. Durante as eluições, a proteína foi sempre recuperada das frações 2 e 3 que, como exemplo, apresentaram pico de absorbância de 1,961 e $1,629 \mathrm{~nm}$, respectivamente, em comparação com a fração 1 , exibindo $0,562 \mathrm{~nm}$.

A realização da diálise é fundamental para eliminar a ureia da amostra e também é uma alternativa para tentar recuperar a forma enovelada (nativa) da proteína recombinante, deixando apenas os epítopos comumente expostos. Durante a diálise, foi possível visualizar a precipitação das proteínas (Figura 29), evidenciando sua insolubilidade. Em decorrência dessa precipitação, uma grande quantidade de proteína rMCP acabou sendo perdida. A utilização da coluna de $3 \mathrm{kDa}\left(\right.$ Amicon $\left.^{\circledR}\right)$ foi necessária para concentrar a proteína rMCP. 
Figura 29 - Diálise da proteína rMCP após a purificação desnaturante
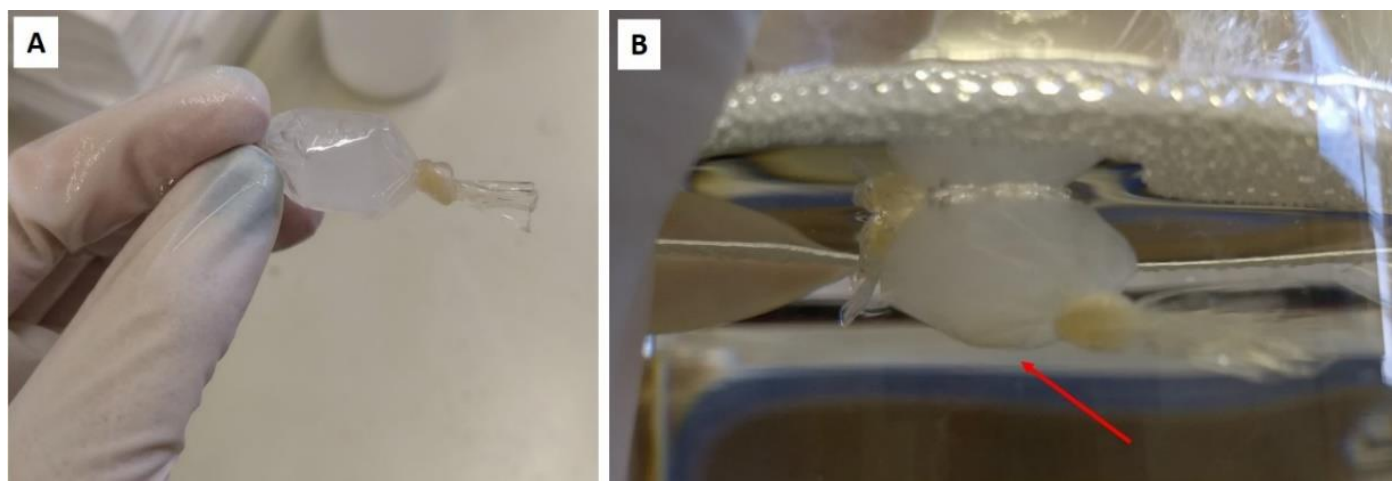

Legenda: A - saco de diálise com as porções da eluição da proteína rMCP, B - saco de diálise ao final do processo, seta evidenciado a precipitação da proteína. Fonte: Própria autoria.

A quantificação da proteína rMCP purificada, pelo método Bradford, resultou, em média, $250 \mu \mathrm{g} / \mathrm{mL}$, uma concentração abaixo do esperado pelo padrão de superexpressão atingido; entretanto, por se tratar de uma proteína insolúvel e com tantas etapas para obtenção de uma proteína de qualidade, pode-se considerar razoável visto ser uma proteína inédita para um ranavírus brasileiro. A figura 30 apresenta os resultados do WB do produto final obtido, a proteína $\mathrm{rMCP}$ purificada, revelados pela reatividade com os anticorpos anti-His-Tag e anti-Iridovírus.

Figura 30 - WB da proteína rMCP purificada

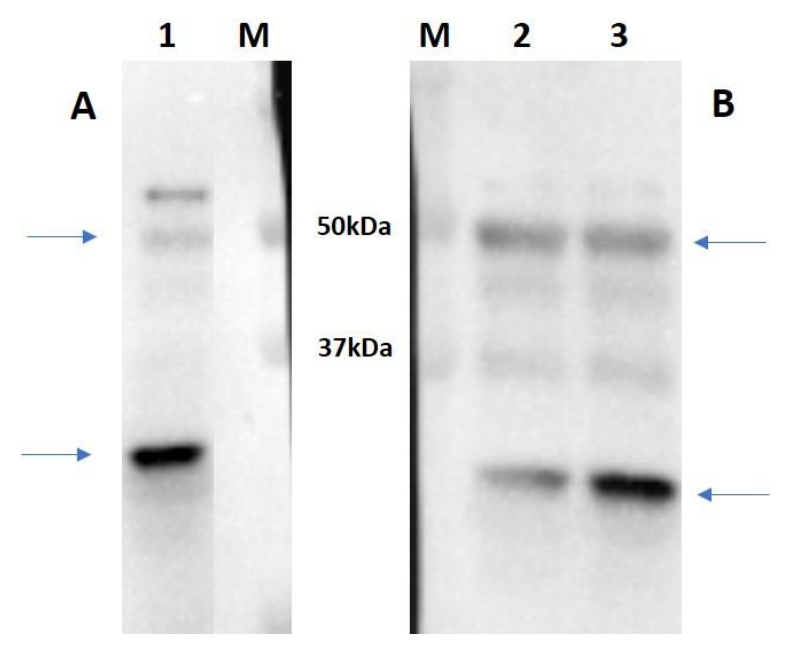

Legenda: A - 1: amostra proteica marcada com o anticorpo anti-His-Tag, M: marcador de massa molecular (Precision Plus Protein ${ }^{\mathrm{TM}}$ Kaleidoscope ${ }^{\mathrm{TM}}$, Bio-Rad); B - M: marcador de massa molecular, 2 e 3: amostras proteicas marcadas com o anticorpo anti-Iridovírus. Setas evidenciando a reatividade da proteína rMCP de peso molecular de 50 e $35 \mathrm{kDa}$. Fonte: Própria autoria. 
Com a utilização da resina Talon ${ }^{\circledR}$ Superflow ${ }^{\mathrm{TM}}$ Metal Affinity Resin (Clontech Laboratories, EUA) foi possível obter volumes maiores da proteína rMCP purificada, apesar de concentrações menores, em média $60 \mu \mathrm{g} / \mathrm{mL}$. Estas foram utilizadas para a imunização dos coelhos devido à pureza da proteína e,em seu tamanho original de $50 \mathrm{kDa}$, estar em maior quantidade (Figura 31). Com o processo de diálise, foi possivel reduzir a concentração de ureia para $0,2 \mathrm{M}$; abaixo dessa concentração, a proteína rMCP precipitava em sua forma insolúvel. Devido a esta instabilidade, uma grande quantidade de proteína ficava retida na membrana de diálise ou nas membranas das colunas de concentradores.

Figura 31 - Purificação da proteína rMCP pela Talon ${ }^{\circledR}$ Superflow ${ }^{\mathrm{TM}}$ e SDS-PAGE

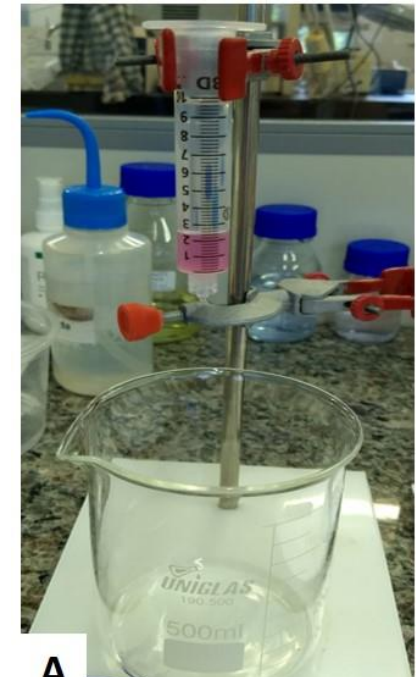

A

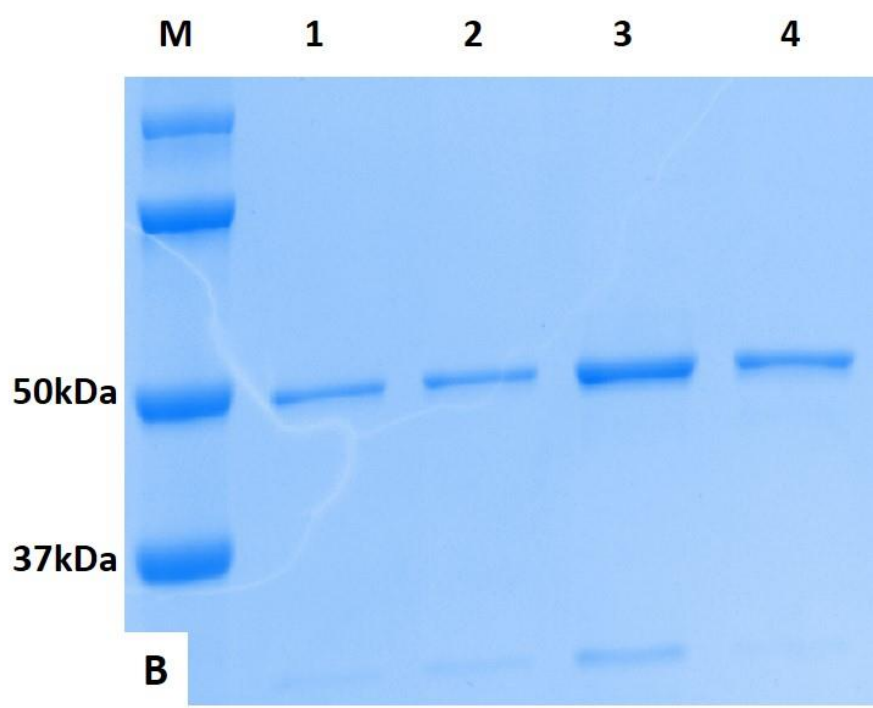

Legenda: A: Coluna de fluxo de gravidade com a resina Talon ${ }^{\circledR}$ Superflow ${ }^{\mathrm{TM}}$ para a purificação da proteína recombinante; B: SDS-PAGE, M: marcador de massa molecular (Precision Plus Protein $^{\mathrm{TM}}$ Kaleidoscope ${ }^{\mathrm{TM}}$, Bio-Rad), 1 a 4 proteína rMCP purificada, evidenciando sua pureza e integridade de 50kDa. Fonte: Própria autoria.

\subsection{Produção dos anticorpos policlonais e Immunoblot}

O periodo de imunização dos coelhos para a produção dos anticorpos antirMCP ocorreu em um total de 42 dias, sendo as aplicações e sangrias realizadas respeitando o intervalo de 14 dias (Figura 32). Estes procedimentos foram realizados com o auxílio de médicos veterinários. A colheita de sangue foi realizada na veia jugular e em média foi obtido $2,0 \mathrm{~mL}$ de soro por animal. 
Figura 32 - Procedimento anestésico e colheita de sangue
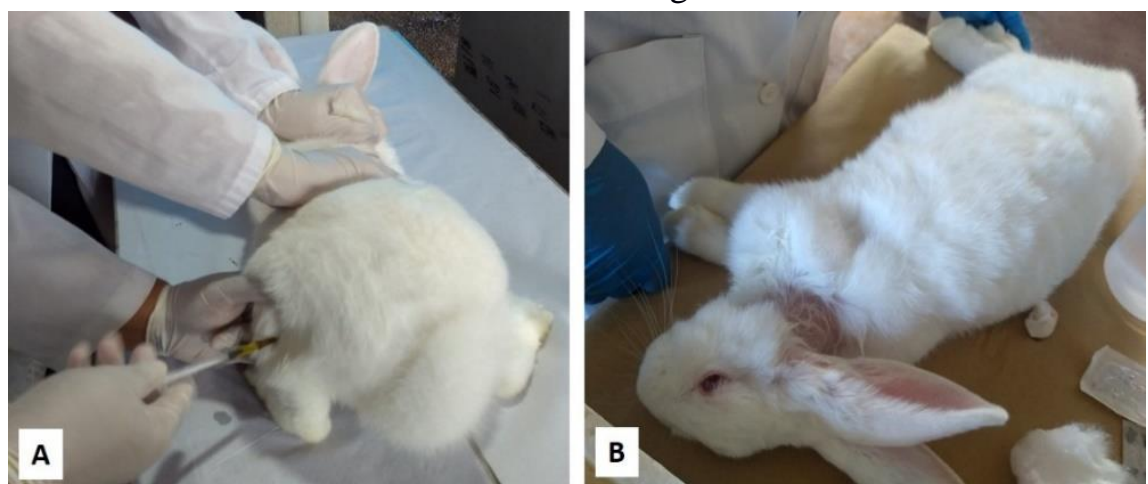

Legenda: A: aplicação da anestesia B: Coelho após a sangria sendo monitorado até a recuperação anestésica. Fonte: Própria autoria.

Após a obtenção dos soros, estes foram utilizados como anticorpo primário (1:2500) na realização do immunoblot. Nas canaletas de amostra do SDS-PAGE, foi aplicada a mesma concentração da proteína rMCP. Após a corrida e transferência para a membrana, foram cortadas as tiras para os três tratamentos, denominados: soro préimune, soro de prova e soro final. Foi possível verificar com o immunoblot a ausência de reatividade entre o soro pré-imune e a proteína rMCP. Por outro lado, o soro de prova, após duas inoculações, apresentou reatividade à proteína rMCP e ao anticorpo secundário anti-Rabbit $\mathrm{IgG}$, demonstrando a produção dos anticorpos policlonais desejados. Após os 42 dias, no soro obtido da última coleta fica evidente o aumento dos níveis de anticorpos policlonais anti-rMCP (Figura 33).

Figura 33 - Immunoblot para avaliação da produção de anticorpos policlonais anti-rMCP

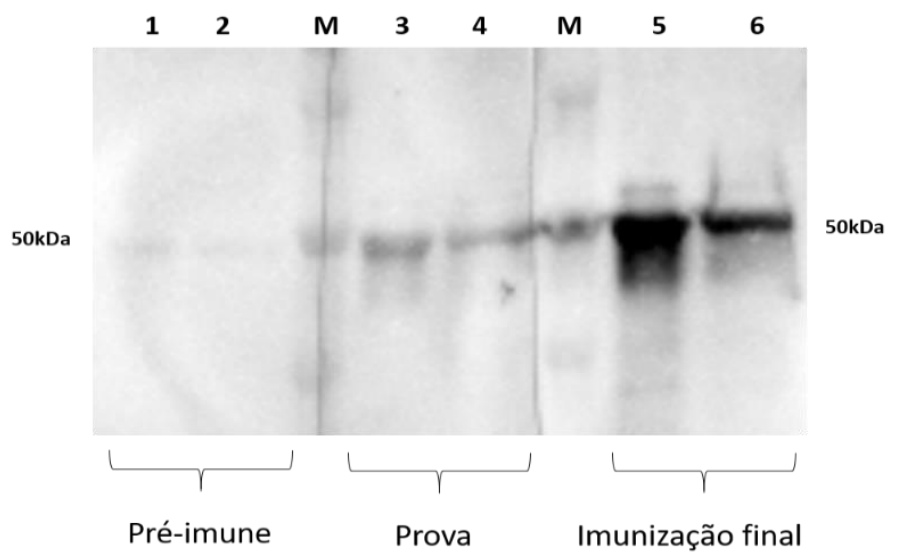

Legenda: M: marcador de massa molecular (Precision Plus Protein ${ }^{\mathrm{TM}}$ Kaleidoscope ${ }^{\mathrm{TM}}$, BioRad); 1 e 2: proteína rMCP, possível reatividade basal em decorrência do anticorpo secundário anti-coelho; 3 e 4: proteína rMCP marcada pela reatividade do soro de prova; 5 e 6: proteína rMCP marcada evidenciando o aumento dos níveis de anticorpos policlonais anti-rMCP. Fonte: Própria autoria. 


\subsection{Produção de soros controle por infecção experimental em tilápias}

A titulação viral da $\mathrm{P} 7$ foi de $10^{5,1} \mathrm{TCID}_{50} / \mathrm{mL}$; portanto, foi realizada a diluição com meio de manutenção (MEM 2\% SFB) para que a suspensão viral inoculada estivesse a $10^{3} \mathrm{TCID}_{50} / \mathrm{mL} /$ peixe. Por se tratar de um isolado que passou por sucessivas passagens em células BF-2, uma relativa atenuação da virulência é factível. O procedimento de inoculação intraperitoneal de $100 \mu \mathrm{L}$ ocorreu com os animais anestesiados (Figura 34 - A), rapidamente transferidos para um balde com aeração para a retomada de consciência e devolução em suas respectivas caixas.

Antes da primeira inoculação foram obtidos soro pré-imune e o pool tecidual (fígado, baço e rim). O volume de soro obtido ficou entre 50 a $200 \mu \mathrm{L}$, variando pela quantidade de sangue obtida em cada tilápia (Figura 34 - B e C).

Figura 34 - Procedimento de inoculação e colheita de sangue
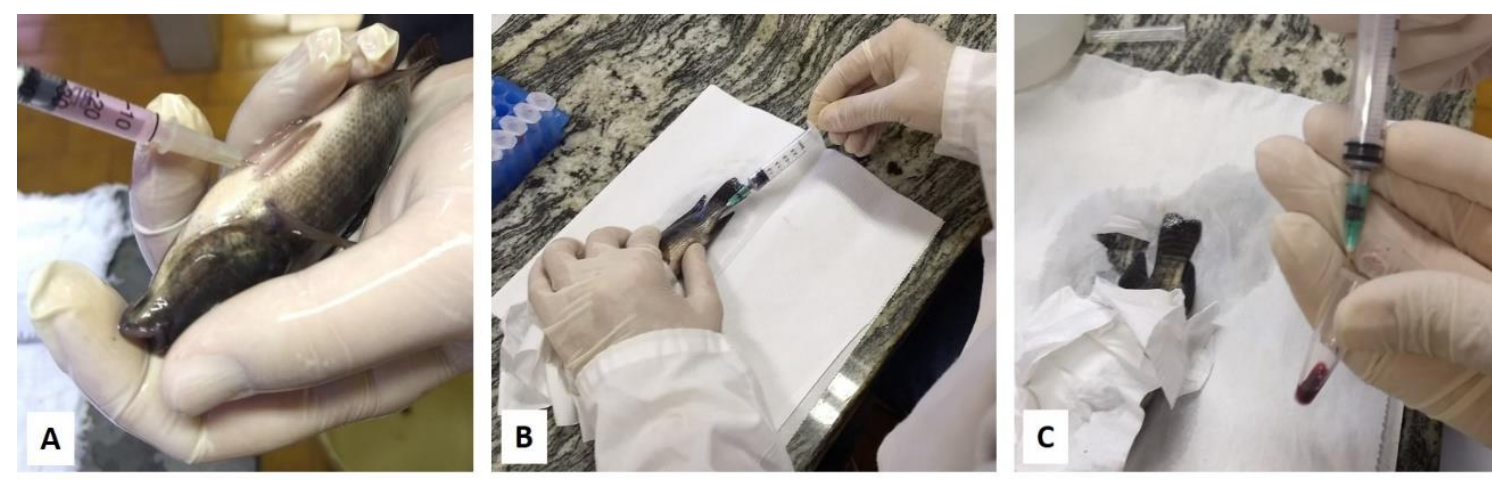

Legenda: A: inoculação na região intraperitoneal; B: procedimento de venopunção caudal; C: transferência do sangue para tudo de $1,5 \mathrm{~mL}$ lentamente para não provocar a lise das hemácias, antes da coagulação. Fonte: Própria autoria.

$\mathrm{Na}$ PCR, as amostras teciduais coletadas antes das inoculações foram negativas para vírus do gênero Ranavirus. Ao final da infecção experimental, o restante das amostras teciduais (pós-inoculação) também foram processadas por PCR e foram todas negativas (Figura 35). Bem como, os animais não apresentaram sinais clínicos aparentes da doença (análise macroscópica), sendo que o grupo controle e o infectado apresentaram as mesmas características. Além disso, em todo o período de realização da infecção experimental, nenhum animal veio a óbito, o que poderia indicar que o FV3- 
símile realmente possa ter sofrido atenuação ou ainda ser de baixa virulência para tilápias.

Figura 35 - Gel de agarose da PCR com os marcadores moleculares: MCP2 e ORF53R (1)

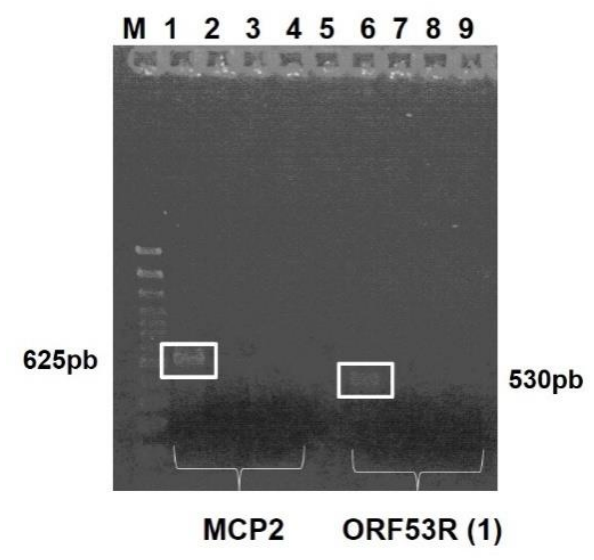

Legenda: Gel de agarose 1,5\%. M: Marcador de massa molecular (100 pb DNA Ladder, Invitrogen); 1 e 6: controles positivos - DNA viral FV3-símile; 4 e 9: $\mathrm{H}_{2} \mathrm{O}$ - Controle negativo da reação de PCR; 2, 3, 7 e 9: amostras do pool de tecidos das tilápias. Fonte: Própria autoria.

Entretanto, na análise histopatológica (microscópica), os dois grupos diferiram principalmente pela presença de pequenos pontos de necrose no tecido hepático dos indivíduos inoculados com o FV3-símile, sendo característica comumente encontrada em infecções por Ranavirus. Adicionalmente, esclerose nos vasos sanguíneos, necrose na cápsula esplênica, necrose em hepatócitos e ácinos pancreáticos foram observados (Figura 36). Centros melanomacrófagos esplênicos foram observados nos dois grupos da infecção experimental, inoculados e não inoculados com o vírus. 
Figura 36: Fotomicrografia de órgão de tilápia. Grupo controle negativo (sem inoculação do FV3símile) e grupo controle positivo (indivíduos inoculados com FV3-símile)

\section{Controle negativo}

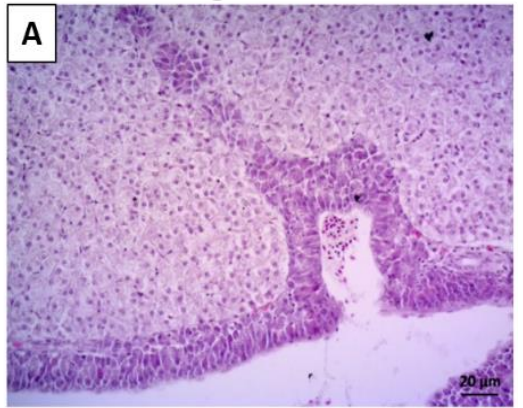

\section{Controle positivo}
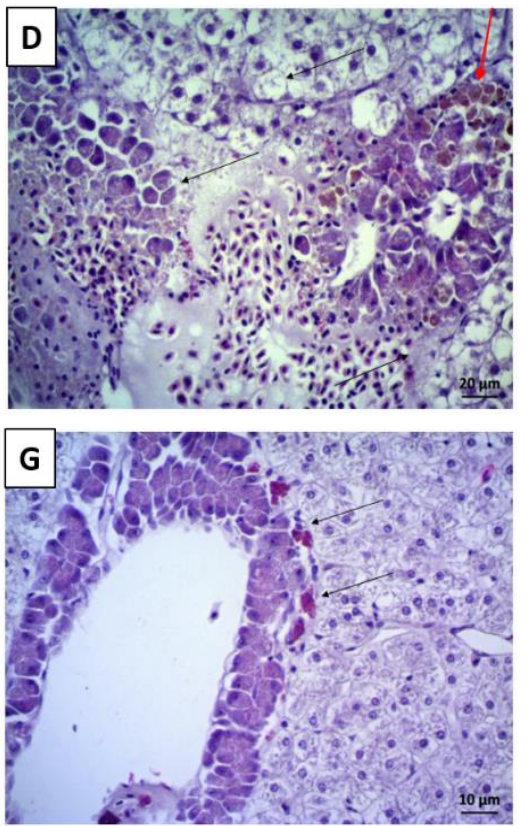
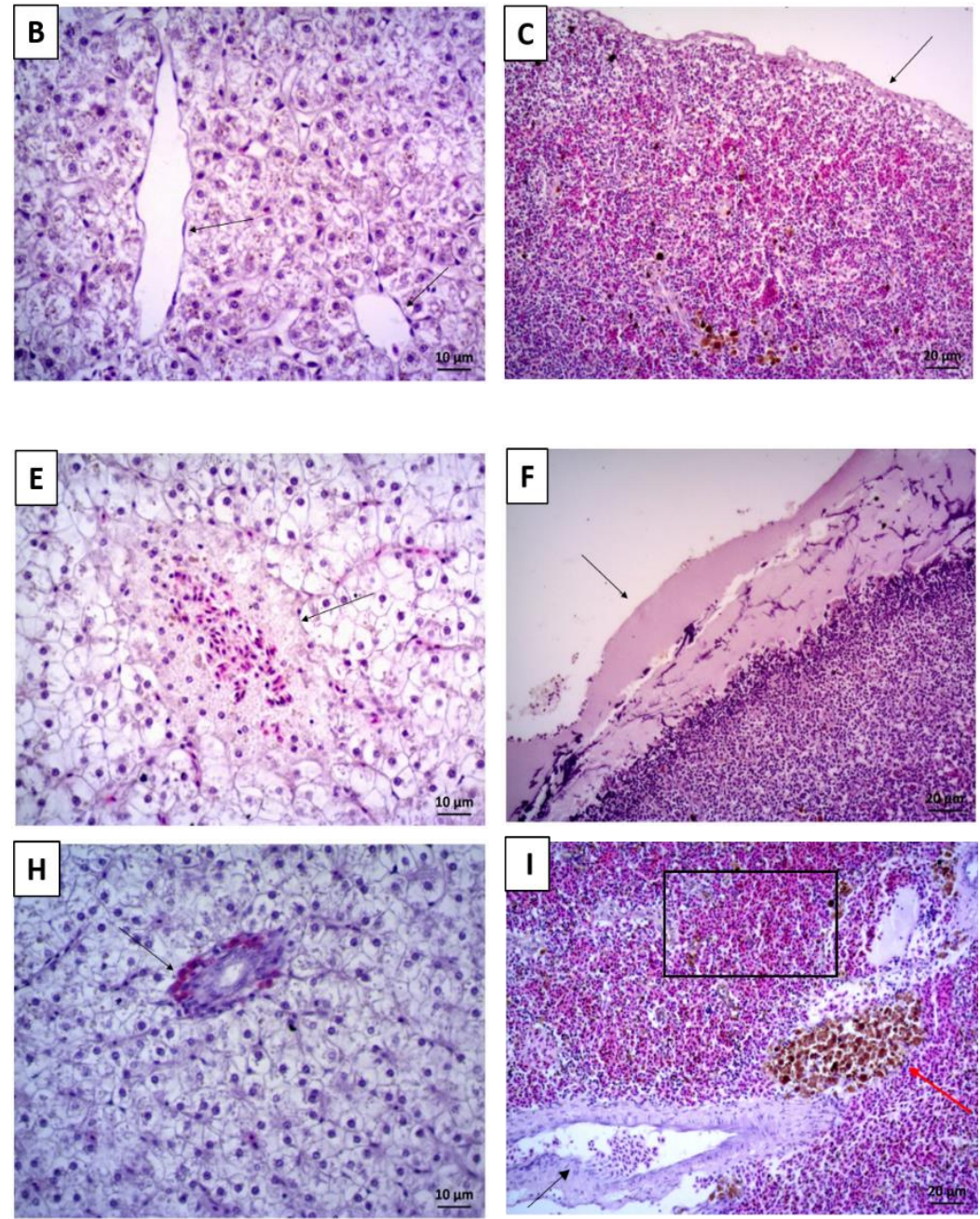

Legenda: Grupo controle negativo: A - ausência de necrose, hepatopâncreas (200x); B- seta indicando vasos sanguíneos sem necrose, fígado (400x); C-seta indicando ausência de necrose na cápsula esplênica, baço (200x); Grupo controle positivo: D -hepatopâncreas: áreas em necrose (setas pretas) e melanomacrófagos (seta vermelha) (400x). $\mathbf{E}$ - vaso em necrose, fígado (400x); $\mathbf{F}$ - necrose e espessamento da cápsula esplênica, baço (200x); G - seta indicando a presença de eosinófilos, hepatopâncreas (400x); H -seta indicando vaso com eosinófilos, fígado (400x); I -Destaque para região hemorrágica (quadrado), vaso com esclerose (seta preta) e centros de melanomacrófagos (seta vermelha), baço (200x). Fonte: Própria autoria. 


\subsection{Padronização do Teste de ELISA-IB}

Esperava-se obter leituras de DOMÁx próximas do valor 1,0; entretanto, com as análises do tempo de reação do substrato e bloqueio $(\mathrm{HCl})$ não demostraram ocorrer variações significativas nos valores das absorbâncias, mesmo variando as concentrações da proteína, dos anticorpos e soros, os valores médios daDO ${ }_{\mathrm{MÁx}}$ chegaram próximos de 0,8. Desta forma, foi padronizado o tempo de 30 min de reação com o TMB, com leitura a 370nm e, seguido por bloqueio da reação com leitura a 450nm (Figura 37).

Figura 37 - Exemplificação da coloração da placa de ELISA nas leituras de DO por espectrometria

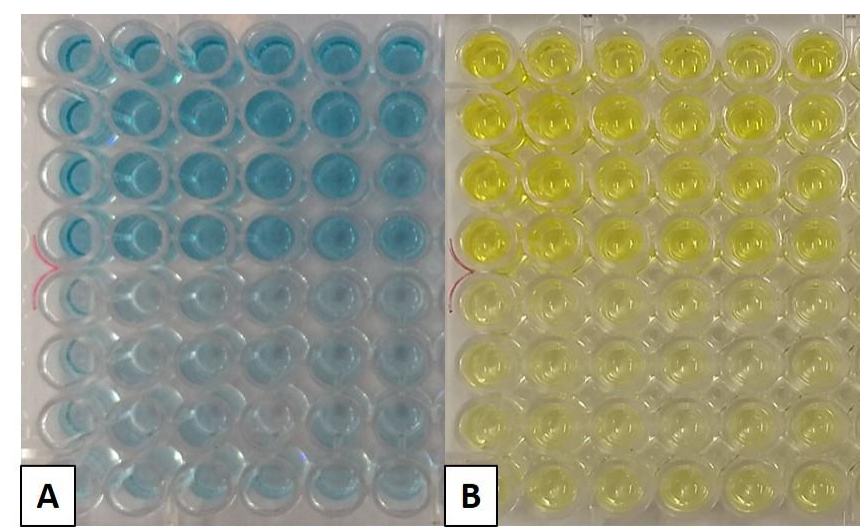

Legenda: Placa de ELISA (Costar 3590). A: coloração após a adição de TMB, leitura realizada no comprimento de onda de 370nm; B: coloração após o bloqueio com $\mathrm{HCl}$, leitura no comprimento de onda de 450nm. Fonte: Própria autoria.

A menor concentração de proteína $\mathrm{rMCP}(\mathrm{AV})$ que apresentou a maior DOMÁx, portanto, descontando as cavidades correspondentes do Ac, foi a de $2,5 \mu \mathrm{g} / \mathrm{mL}$. Entretanto, a concentração de $5 \mu \mathrm{g} / \mathrm{mL}$ também foi utilizada nas padronizações com os soros de peixes e anfíbios. Outra padronização definida diante do observado, foi a utilização da diluição de 1:1000 do anticorpo policlonal anti-rMCP (anticorpo de bloqueio), uma vez que não necessariamente as diluições menores (ex: 1:50) apresentaram leituras de DO maiores. Por tanto, a DOMÁx foi calculada para cada teste, sendo o valor máximo de ligação do anticorpo de bloqueio naquele dado momento.

No ELISA-IB utilizando o soro de peixes, produzidos pela infecção experimental em tilápias, não foi possível observar diferença nas leituras de absorbância entre as amostras que seriam os controles positivos e controles negativos do experimento (Tabela 6). Estes valores de DO encontrados para os controles dos soros 
não diferiram estatisticamente (teste $\mathrm{t}=0,0014$ ), o que demostra que com a técnica empregada no ELISA-IB não foi possível encontrar diferenças nos anticorpos produzidos pelos animais dos grupos controle.

Tabela 6 - Valores de DO observados no ELISA-IB de soros de peixe

\begin{tabular}{|c|c|c|c|c|c|c|c|}
\hline \multirow{2}{*}{\multicolumn{2}{|c|}{$\begin{array}{l}\text { DO média } \\
\text { Amostra }\end{array}$}} & \multicolumn{6}{|c|}{$2,5 \mu \mathrm{g} / \mathrm{mL}$} \\
\hline & & Pool & 1 & 2 & 3 & 4 & 5 \\
\hline \multirow{2}{*}{$\mathbf{A V}$} & soros + & 0,937 & 0,945 & 0,954 & 0,970 & 0,942 & 0,924 \\
\hline & soros - & 0,878 & 0,846 & 0,816 & 0,844 & 0,807 & 0,745 \\
\hline \multirow{2}{*}{ Ac } & soros + & 0,356 & 0,326 & 0,355 & 0,337 & 0,328 & 0,325 \\
\hline & soros - & 0,373 & 0,357 & 0,353 & 0,252 & 0,341 & 0,342 \\
\hline \multicolumn{2}{|c|}{ DO $_{\text {TESTE }}$} & Pool & 1 & 2 & 3 & 4 & 5 \\
\hline \multicolumn{2}{|c|}{ soros + } & 0,582 & 0,619 & 0,599 & 0,634 & 0,614 & 0,600 \\
\hline \multicolumn{2}{|c|}{ soros - } & 0,505 & 0,489 & 0,463 & 0,593 & 0,466 & 0,403 \\
\hline
\end{tabular}

Legenda: Valores de DO médias na leitura a 370nm. Placa sensibilizada com 2,5 $\mu \mathrm{g} / \mathrm{mL}$ de AV e Ac; soros positivos e negativos na diluição de 1:100; anticorpo de bloqueio na diluição 1:1000 (policlonal anti-rMCP) e; anticorpo conjugado na diluição de 1:5000. DO TESTE de soros positivos (+) e negativos (-). Amostras: Pool- mistura de todos os soros de cada indivíduo por grupo controle; 1 a 5 - amostras de um único indivíduo de cada grupo controle. Fonte: Própria autoria.

Quando calculada a porcentagem de inibição (PI) de cada amostra a partir

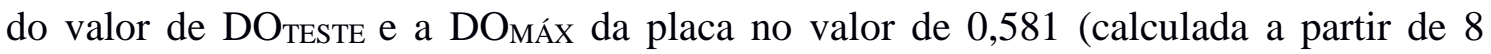
poços), os dois grupos diferiram entre si (Tabela 7). A PI encontrada nos soros do grupo controle negativo foram de até a 30,67\% de inibição. Entretanto, o ponto de corte foi de $48,57 \%$, então só poderia ser considerada uma amostra positiva com PI acima desse valor. As inibições observadas foram, portanto, apenas ligações inespecíficas. 
Tabela 7 - Valores da porcentagem de inibição dos soros controle de peixes

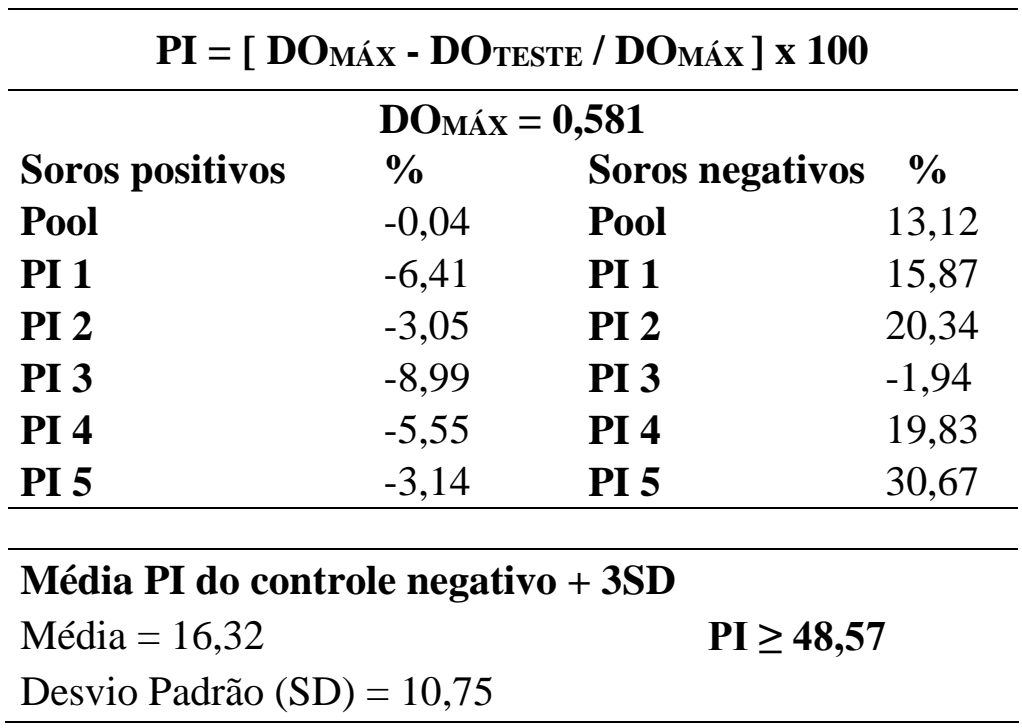

Legenda: Amostras: Pool - mistura de todos os soros de cada indivíduo por grupo controle; 1 a 5 - amostras de um único indivíduo de cada grupo controle. Fonte: Própria autoria.

Para o ELISA-IB utilizando-se os soros de anfíbios a DOMÁx foi obtida pela média de 16 poços do AV menos 16 poços de Ac. Foi realizado o teste de ELISA-IB com as duas concentrações da proteína rMCP e extrato de $E$. coli, $2,5 \mu \mathrm{g} / \mathrm{mL}$ e $5 \mu \mathrm{g} / \mathrm{mL}$, as DOMÁx foram de 0,349 e 0,806 respectivamente (Tabela 8).

Tabela 8 - Valores das DO observadas para o cálculo da DOMÁx

\begin{tabular}{|c|c|c|c|c|c|c|c|c|}
\hline DO & \multicolumn{4}{|c|}{$2,5 \mu \mathrm{g} / \mathrm{mL}$} & \multicolumn{4}{|c|}{$5 \mu \mathrm{g} / \mathrm{mL}$} \\
\hline \multirow{4}{*}{ AV } & 0,635 & 0,545 & 0,571 & 0,583 & 1,122 & 1,071 & 1,071 & 1,071 \\
\hline & 0,598 & 0,532 & 0,535 & 0,547 & 1,008 & 0,998 & 0,964 & 0,996 \\
\hline & 0,556 & 0,505 & 0,500 & 0,496 & 0,950 & 0,936 & 0,876 & 0,928 \\
\hline & 0,486 & 0,536 & 0,526 & 0,515 & 0,955 & 0,931 & 0,958 & 0,956 \\
\hline \multirow{4}{*}{ Ac } & 0,190 & 0,192 & 0,210 & 0,185 & 0,182 & 0,178 & 0,168 & 0,175 \\
\hline & 0,209 & 0,197 & 0,202 & 0,185 & 0,193 & 0,190 & 0,179 & 0,181 \\
\hline & 0,181 & 0,181 & 0,185 & 0,182 & 0,180 & 0,169 & 0,168 & 0,170 \\
\hline & 0,217 & 0,199 & 0,187 & 0,179 & 0,180 & 0,196 & 0,205 & 0,189 \\
\hline DO AV & \multicolumn{4}{|c|}{0,542} & \multicolumn{4}{|c|}{0,987} \\
\hline DO Ac & \multicolumn{4}{|c|}{0,193} & \multicolumn{4}{|c|}{0,181} \\
\hline DOMÁx & \multicolumn{4}{|c|}{0.349} & \multicolumn{4}{|c|}{0,806} \\
\hline
\end{tabular}

Legenda: Valores de DO na leitura a 450nm. Placa sensibilizada com $2,5 \mu \mathrm{g} / \mathrm{mL}$ de AV e Ac e $5 \mu \mathrm{g} / \mathrm{mL}$ de AV e Ac; anticorpo de bloqueio na diluição 1:1000 e anticorpo conjugado na diluição de 1:5000. Valores médios de DO AV e DO Ac das 16 cavidades. Fonte: Própria autoria. 
Como os soros de rãs-touro eram provenientes de uma única propriedade e não foi possível uma padronização da metodologia a partir dos soros de peixes, foram realizados os cálculos da PI com base em duas diluições para os soros e nas duas concentrações de proteínas na sensibilização da placa. Os valores de DOTESTE são apresentados na Tabela 9.

Tabela 9 - Valos de DO observadas no ELISA-IB do soro de anfíbios

\begin{tabular}{ll|cccccc|cccccc}
\hline DO média & \multicolumn{6}{c|}{$\mathbf{2 , 5} \boldsymbol{\mu g} / \mathbf{m L}$} & \multicolumn{5}{c}{$\mathbf{5} \boldsymbol{\mu g} / \mathbf{m L}$} \\
\hline \multicolumn{2}{l|}{ Amostra } & $\mathbf{1}$ & $\mathbf{2}$ & $\mathbf{3}$ & $\mathbf{4}$ & $\mathbf{5}$ & $\mathbf{6}$ & $\mathbf{1}$ & $\mathbf{2}$ & $\mathbf{3}$ & $\mathbf{4}$ & $\mathbf{5}$ & $\mathbf{6}$ \\
\hline \multirow{2}{*}{ AV } & soro 1:50 & 0,514 & 0,431 & 0,418 & 0,355 & 0,393 & 0,429 & 0,948 & 0,939 & 0,897 & 0,859 & 0,909 & 1,024 \\
& soro 1:100 & 0,485 & 0,424 & 0,418 & 0,375 & 0,410 & 0,415 & 0,946 & 0,920 & 0,922 & 0,888 & 0,919 & 0,987 \\
\hline \multirow{2}{*}{ Ac } & soro 1:50 & 0,105 & 0,087 & 0,108 & 0,090 & 0,086 & 0,090 & 0,094 & 0,085 & 0,087 & 0,086 & 0,091 & 0,095 \\
& soro 1:100 & 0,121 & 0,096 & 0,087 & 0,090 & 0,095 & 0,092 & 0,098 & 0,092 & 0,091 & 0,091 & 0,089 & 0,107 \\
\hline
\end{tabular}

\begin{tabular}{lcccccc|cccccc}
\hline DOTESTE & $\mathbf{1}$ & $\mathbf{2}$ & $\mathbf{3}$ & $\mathbf{4}$ & $\mathbf{5}$ & $\mathbf{6}$ & $\mathbf{1}$ & $\mathbf{2}$ & $\mathbf{3}$ & $\mathbf{4}$ & $\mathbf{5}$ & $\mathbf{6}$ \\
\hline Diluição 1:50 & 0,409 & 0,344 & 0,310 & 0,265 & 0,307 & 0,339 & 0,854 & 0,854 & 0,810 & 0,773 & 0,818 & 0,929 \\
Diluição 1:100 & 0,364 & 0,329 & 0,331 & 0,285 & 0,315 & 0,323 & 0,848 & 0,828 & 0,831 & 0,797 & 0,830 & 0,880 \\
\hline
\end{tabular}

Legenda: Valores de DO médias na leitura a 450nm. Placa sensibilizada com $2,5 \mu \mathrm{g} / \mathrm{mL}$ e 5 $\mu \mathrm{g} / \mathrm{mL}$ de AV e Ac; soros na diluição de 1:50 e 1:100; diluição de 1:1000 do anticorpo de bloqueio (policlonal anti-rMCP) e anticorpo conjugado na diluição de 1:5000. DO TESTE para cada indivíduo numerado de 1 a 6 . Fonte: Própria autoria.

Com o teste de ELISA-IB foi possível observar PI variando de 1 até 24\%, quando avaliado o AV na concentração de $2,5 \mu \mathrm{g} / \mathrm{mL}$, nas duas diluições do soro; cinco das seis amostras sofreram uma redução na DOMÁx indicando que possivelmente alguns anticorpos ocuparam os sítios de ligação no $\mathrm{AV}$, indisponibilizando os sítios ao anticorpo de bloqueio. Entretanto, na concentração de $5 \mu \mathrm{g} / \mathrm{mL}$ de $\mathrm{AV}$, apenas a amostra quatro manteve esse padrão de redução dos sítios de ligação disponíveis para o anticorpo de bloqueio (Tabela 10). Estes resultados demostram que os títulos de anticorpos dos soros das rãs estão baixos, provavelmente apenas a amostra quatro é de um animal soro reativo para Ranavirus. Embora, sem uma amostragem epidemiológica, não foi possível traçar o ponto de corte para este percentual de inibição ser consideradoaquele de uma amostra positiva. 
Tabela 10 - Valores da porcentagem de inibição dos soros de anfíbios

\begin{tabular}{|c|c|c|c|}
\hline \multicolumn{4}{|c|}{ PI = [DOMÁx - DO $_{\text {TESTE }} /$ DOMÁx $]$ x 100} \\
\hline \multicolumn{4}{|c|}{ 2,5 $\mu \mathrm{g} / \mathrm{mLDOMÁx}=0,349$} \\
\hline Diluição 1:50 & $\%$ & Diluição 1:100 & $\%$ \\
\hline PI 1 & $-17,03$ & PI 1 & $-4,28$ \\
\hline PI 2 & 1,45 & PI 2 & 5,89 \\
\hline PI 3 & 11,33 & PI 3 & 5,32 \\
\hline PI 4 & 24,08 & PI 4 & 18,35 \\
\hline PI 5 & 12,05 & PI 5 & 9,76 \\
\hline PI 6 & 2,88 & PI 6 & 7,61 \\
\hline \multicolumn{4}{|c|}{ 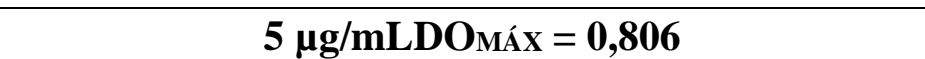 } \\
\hline Diluição 1:50 & $\%$ & Diluição 1:100 & $\%$ \\
\hline PI 1 & $-6,02$ & PI 1 & $-5,28$ \\
\hline PI 2 & $-5,96$ & PI 2 & $-2,79$ \\
\hline PI 3 & $-0,56$ & PI 3 & $-3,17$ \\
\hline PI 4 & 4,03 & PI 4 & 1,06 \\
\hline PI 5 & $-1,55$ & PI 5 & $-3,04$ \\
\hline PI 6 & $-15,33$ & PI 6 & $-9,25$ \\
\hline
\end{tabular}

Legenda: Destaque em azul para a amostra 4 que apresentou inibição em qualquer diluição e concentração do AV. Fonte: Própria autoria. 


\section{DISCUSSÃO}

As infecções virais são um dos fatores mais limitantes da aquicultura intensiva, destaque para muitos iridovírus que são de notificação obrigatória junto à Organização Mundial de Saúde Animal (OIE, 2019; MACHIMBIRIKE et al., 2019). Medidas de manejo sanitário devem ser adotadas e constantemente reforçadas na psicultura e ranicultura, uma vez que, não existe um sistema de criação ideal que seja livre de patógenos, todos estão sujeitos a problemas, mas estes podem ser minimizados quando medidas sanitárias são aplicadas (MARTIS, 2004; HIPOLITO, 2004). Diante deste desafio, o MAPA pretende implementar novas diretrizes na área de sanidade de organismos aquáticos, para incluir no Programa Nacional de Saúde Animal os patógenos da família Iridoviridae.

Os Ranavirus, por contituírem um grupo de vírus emergentes, são ainda mais preocupantes quando introduzidos em uma nova população, pois modelos matemáticos demonstram que uma população de anfíbios (selvagens) isolada pode ser extinta em cinco anos após a introdução de um ranavírus (FORZÁN et al., 2017), visto que as ranaviroses não apresentam tratamento e os vírus do gênero são considerados estáveis em condições controladas, capazes de suportar uma grande amplitude de $\mathrm{pH}$, temperaturas altas e baixas e resistência à dessecação, permanecendo viáveis por dias até anos, apesar de não poderem manter a mesma estabiladade em ambientes ecológicos, devido as interações com a comunidade biótica (LANGDON et al., 1986; BRUNNER et al., 2015). Neste caso, a melhor estratégia de controle das infecções por ranavírus são medidas preventivas praticadas no manejo sanitário e no monitoramento da ocorrência das ranaviroses. Por conseguinte, estudos como o desenvolvido com Ranavirus no presente trabalho podem contribuir diretamente com subsídios para o estabelecimento do programa sanitário, pois o diagnóstico laboratorial é parte fundamental do conjunto de informações para as soluções dos problemas sanitários sob investigação.

Esta é a primeira vez que um isolado brasileiro de Ranavirus é utilizado para a produção de proteína recombinante. O gene MCP foi o escolhido por ser a principal proteína imunogênica da família Iridoviridae, pois está presente em maior quantidade no vírus, por isso, têm sido o gene mais utilizado na literatura para produção 
de proteína recombinante (KIM; JUNG; LEE, 2007; LIU et al., 2015; KIM et al., 2015; MAHARDIKA; MASTUTI, 2015; ZHOU et al., 2015).

O primeiro vetor utilizado, pET SUMO (Invitrogen), parecia uma excelente alternativa a ser aplicada na clonagem e expressão, pois a fusão com a proteína SUMO facilita a solubilização e recuperação da proteína recombinante. Como o kitChampion ${ }^{\mathrm{TM}}$ pET SUMO "Protein Expression System" é completo com todos os componentes necessários e padronizado, esperava-se obter a proteína rMCP em sua forma solúvel e em grande quantidade. Entretanto, não ocorreu a solubilização facilitada pela expressão recombinante com a proteína SUMO.

O processo de clonagem com o pET SUMO foi fácil e de elevada eficiência, entretanto iniciada a expressão, os problemas na baixa expressão e solubilidade da proteína rMCP foram observados. Seguindo as recomendações da literatura: Ahmad et al. (2018), Fakruddin et al. (2013) e Overton (2014), foram adotadas as medidas de redução de temperatura durante a expressão, aumento do volume da cultura, aeração, adição de glicose, pH, variação nas concentrações de IPTG para a indução e tempo de expressão após a indução. Embora todas as tentativas, a proteína rMCP foi produzida na sua forma insolúvel com corpos de inclusão, baixa quantidade e de difícil purificação, mesmo utilizando os kits de purificação e metodologias recomendadas pela marca do vetor $\mathrm{pET}$ SUMO.

Mahardika e Mastuti (2015) utilizaram o mesmo vetor pET SUMO para expressão o gene MCP do Megalocytivirus, Grouper sleepy disease iridovirus (GSDIV); os autores relatam o sucesso desta metodologia na produção da proteína de $49,5 \mathrm{kDa}$. Contudo, a fim de testar a eficiência da proteína recombinante em garoupas (Cromileptes altivelis) utilizaram a proteína bruta, diretamente do extrato de E. coli inativado com formalina $0,03 \%$, ouseja, não realizaram a purificação da proteína MCP recombinante produzida com o vetor pETSUMO. Podemos extrapolar e supor que também tiveram problemas nesta etapa, pois os autores não relatam sobre a solubilidade da proteína recombinante. Vale ressaltar que mesmo utilizando-se a proteína bruta, com todas as demais proteínas produzidas pela bactéria hospedeira e o fragmento proteico SUMO, a vacina testada apresentou potencial para ser utilizada para esta espécie de peixe. O mesmo grupo de pesquisa ao repetir a imunização utilizando adjuvantes $\left(\right.$ Montanide $^{\mathrm{TM}}$ ) para melhorar a eficiência da vacina, conseguiram a maior porcentagem 
de sobrevivência relativa, cerca de $77 \%$ das garoupas desafiadas com o vírus GSDIV (MAHARDIKA et al., 2016).

Em determinado momento, optou-se por reiniciar a clonagem e expressão do gene MCP utilizando outros vetores comumente utilizados na literatura e outra linhagem de E. coli. O vetor de expressão construído pET28a/MCP, transformado na linhagem Rosetta ${ }^{\mathrm{TM}}(\mathrm{DE} 3)$, produziu a proteína recombinante mais uma vez na forma insolúvel (corpos de inclusão), entretanto, em concentrações maiores e do tamanho esperado para a proteína $\mathrm{rMCP}(50 \mathrm{kDa})$, do que quando o vetor pET28a/MCP foi transformado na linhagem BL21(DE3) OneShot ${ }^{\circledR}$. Uma explicação para o fato seria a presença de códons raros para a $E$. coli no gene MCP, visto que, não foi realizado nem um tipo de edição no gene do isolado brasileiro.

Um códon raro é um códon de baixo uso em procariotos; no caso de E. coli, existem cerca de 30 códons de sentido sinônimo de baixo uso, mas apenas 20 deles são considerados códons raros bacterianos. Destes, são classificados dois grupos, sete códons usados na freqüência menor de 0,5\% (AGG, AGA, CGA, CUA, AUA, CCC e CGG - Grupo I) e 13 códons utilizados na frequência superior de 0,5\% (ACA, CCU, UCA, GGA, AGU, UCG, CCA, UCC, GGG, CUC, CUU, UCU e UUA - Grupo II). Estudos demonstraram que todos os códons do Grupo I e os seis primeiros do Grupo II podem causar problemas traducionais em E. coli (CHEM; TEXADA, 2006). No gene MCP do FV3-símile são encontrados todos os códons raros do Grupo I. Alguns estudos utilizaram ferramentas de edição para alterar os códons raros do gene MCP e facilitar a tradução pela $E$. coli ou outro micro-organismo escolhido. Por exemplo, no trabalho de Zhou et al. (2015), até mesmo utilizando-se levedura (Pichia pastoris) para a expressão do gene MCP do ranavírus GSIV (Chinese giant salamander iridovirus), foi realizada a otimização dos codons para remover os menos utilizados pela $P$. pastori, sendo este novo gene sintetizado pela empresa GenScript.

Outro problema relacionado a códons raros seria os aglomerados de códons AGG/AGA, CUA, AUA, CGA ou CCC que podem reduzir tanto a quantidade como a qualidade (tamanho) da proteína sintetizada (KANE, 1995). No caso da proteína rMCPa expressão de aglomerados de códons raros não foi observada, bem como não foram identificados códons de parada (TAA) ao longo do gene, apenas no final, conforme esperado. Portanto, o fragmento proteico de $35 \mathrm{kDa}$ da $\mathrm{rMCP}$, confirmado pela expectrofotometria de massa como parte da proteína $\mathrm{MCP}$, pode ser fruto de algum 
outro fator biológico, comoa alteração conformacional durante o processamento da proteína, uma isoforma da proteína ou fruto de uma ação proteolítica,embora as linhagens utilizadas sejam desprovidas de protease. Vale ressaltar, que foi verificado maior quantidade da proteína de fragmento menor na linhagem BL21(DE3) OneShot ${ }^{\circledR}$ do que na Rosetta ${ }^{\mathrm{TM}}(\mathrm{DE} 3)$.

A utilização de sonicador ultrassônico de ponteira e ureia possibilitaram a solubilização temporária da proteína $\mathrm{rMCP}$, facilitando sua purificação desnaturante seguida de diálise, principalmente na tentativa de se buscar o enovelamento (refolding) da proteína rMCP. A proteína rMCP inoculada nos coelhos produziu anticorpos policlonais anti-rMCP em grande quantidade já na segunda inoculação. Os soros coletados dos animais reagiram com a proteína viral ao Immunoblot, apresentando o tamanho de banda esperada de 50kDa. Alem disso, essa reatividade demonstra que o anticorpo policlonal anti-rMCP produzido pode ser utilizado em outros testes de diagnóstico além do $\mathrm{WB}$, podendo ser aplicado em análises de microscopia de imunofluorescência como anticorpo primário, para a identificação da expressão do MCP em cultivo celular, ou ainda na microscopia eletrônica semelhante uitilizada por Neves et al., (2016) na identificação de partículas virais (ranavírus) em amostras de ranários do estado de São Paulo.

Obtendo-se os imunorreagentes objetivados no presente trabalho, a proteína rMCP e anticorpos policlonaisanti-MCP, iniciou-se a padronização do ensaio imunoenzimático delineado com base nos princípios do ELISA-indireto e no ELISABFL (ELISA de bloqueio de fase líquida) desenvolvido por Esterhuysen, Prehaud, Thomson (1995), utilizando os soros de peixe da infecção experimental e os soros de anfíbios de um ranário comercial. Avaliando-se a quantidade de soro obtida, a partir do volume de sangue amostrado dos peixes e anfíbios, verifica-se que é suficiente para a realização de testes sorológicos, o que realmente reforça a eficácia do procedimento de amostragem não letal.

Kim, Jung e Lee (2007) também utilizaram a proteína recombinante do MCP, do Ranavirus denominado rock bream iridovirus (RBIV), como antígeno viral em um teste de ELISA indireto (ELISA-I), na concentração de $1 \mu \mathrm{g} /$ por poço. O ensaio testou soros de peixes do sul da Coréia (rock bream, Oplegnathus fasciatus); entretanto, neste caso, foi utilizado o anticorpo monoclonal anti-IgM contra rock bream para identificar os anticorpos que se ligaram à proteína recombinante. Como resultado, 
encontram 92,5\% dos soros positivos para infecção com o ranavírus e que a proteína recombinante poderia ser útil para testes sorológicos.

Liu et al. (2015) produziram a proteína recombinante do MCP de um Megalocytivirus, TGIV (grouper iridovirus of Taiwan), e de um Ranavirus, GIV (grouper iridovirus). As duas proteínas foram utilizadas, separadamente, na imunização de coelhos para a produção de anticorpos policlonais denominados anti-TGIV-MCP e anti-GIV-MCP. Estes anticorpos foram eficientes no WB para identificar antígenos virais a partir de amostras teciduais de alevinos de garoupa infectados experimentalmente pelos dois vírus, embora revelando que são sondas espécie específicas, devido à distância dos dois gêneros virais. Além disso, a proteína MCP recombinante de TGIV foi testada como vacina, sendo sua eficiência demostrada por ELISA.

Cinkova et al. (2010) avaliaram a especificidade do anticorpo policlonal de coelhos produzidos contra partículas virais do Ranavirus European catfish virus (ECV). Para isso, foram utilizados nove ranavírus em cultivo celular, sendo testados por WB, imunomicroscopia eletrônica com ouro coloidal e ELISA-direto, onde o anticorpo policlonal foi marcado com peroxidase. Os resultados demonstram a eficiência do anticorpo policlonal nas três técnicas e que, com as devidas padronizações, poderia ser utilizado no diagnóstico do gênero Ranavirus, em amostras de peixes de água doce e anfíbios.

Além dos anticorpos policlonais, anticorpos monoclonais têm sido obtidos para a detecção e caracterização de Ranavirus, principalmente na avaliação da expressão de genes durante a replicação viral por ensaios de imunofluorescência (LIN et al., 2014; LIN et al., 2015; CHEN et al., 2016). Lin et al. (2014) utilizaram $100 \mu \mathrm{g}$ da proteína recombinante do MCP (GIV-MCP-His) de Grouper iridovirus (GIV) para imunizar camundongos, sendo coletados os soros policlonais e preparados os hibridomas e, na sequência, selecionados por ELISA (de 73 clones, 6 foram positivos). Os seis anticorpos monoclonais apresentaram reatividade no WB com a proteína GIVMCP-His, entretanto, um deles apresentou maior reatividade no ELISA e foi escolhido para as demais análises. Com este anticorpo monoclonal, verificou-se a expressão do MCP do GIV durante a replicação viral, sendo revelado pelo WB que é um gene tardio e, pela imunofluorescência, que está presente no citoplasma bem como no núcleo das células infectadas. 
Pesquisas de monitoramento epidemiológico utilizando ferramentas sorológicas têm sido frequentemente realizadas na avaliação de répteis (quelônios) quanto a presença de anticorpos antiranavirais, nos Estados Unidos e na Austrália, principalmente com base no ELISA (JOHNSON et al., 2010; ARIEL et al., 2017; WIRTH et al., 2018).

Como demonstrado por estes trabalhos, os métodos sorológicos apresentam grandes vantagens principalmente quando a doença é endêmica ou está presente em baixa prevalência na população sem sinais clínicos graves, visto que, muitas vezes, não é possível a identificação direta do vírus, pois as partículas virais não estão mais presentes, diferentemente dos anticorpos que podem ser detectados por um longo período de tempo (JARAMILLO et al., 2017; RAHNAMA et al., 2019). Em psiculturas e raniculturas, onde os animais são submetidos a condições de manejo adequadas, por exemplo com água e ração de qualidade, podem ocorrer casos assintomáticos de ranaviroses, que possivelmente seriam detectados por análises sorológicas.

A partir dos resultados do ELISA-IB, avaliando os soros controles produzidos na infecção experimental, não foi possível realizar a padronização do ensaio imunoenzimático. Neste momento, algumas hipóteses são levantadas sobre o real estado de soroconversão destes animais, pois devido à atenuação por passagens sucessivas em cultivo celular, o FV3-símile pode ter perdido sua capacidade de estimulação imunogênica, em particular para tilápias, ou a dose inoculada de suspensão viral não foi suficiente para provocar uma resposta imune humoral; outro ponto que deve ser destacado é a evolução dos vírus do gênero Ranavirus que primeiramente infectavam peixes e depois evoluíram para outras classes de vertebrados ectotérmicos (CHINCHAR; YU; JANCOVICH, 2011), tratando-se portanto de uma estirpe naturalmente avirulenta ou pouco imunogênica para tilápias; além disso, o sistema inume dos teleósteos é modulado por fatores ambientais (TIZARD 2009), como temperaturada água, fatores estressores, como densidade e recurso alimentar; nesse sentido, as tilápias do experimento tiveram esses fatores externos atenuados, o que pode ter interferido na modulação da resposta imune esperada.

Outrossim, vale destacar que este mesmo isolado, FV3-símile da sexta passagem, foi utilizado em outros dois trabalhos de infecção experimental. Em um deles, também em tilápias do Nilo (larvas e juvenis), avaliaram-se três diferentes modelos de infecção, sendo que o autor identificou poucos sinais clínicos, algumas 
alterações hematológicas e histológicas e positividade apenas para algumas larvas, somente ao qPCR, nas concentrações mais elevadas dos tratamentos realizados $\left(10^{3} \mathrm{e}\right.$ $10^{4} \mathrm{TCID}_{50} / \mathrm{mL}$ ); portanto, os animais aparentemente não apresentaram problemas com a infecção e neutralizaram o vírus inoculado (CANDIDO, 2018). Em outro trabalho, realizou-se infecção experimental em rãs-touro (girinos e adultos) para avaliar a susceptibilidade desses animais frente ao FV3-símile em três dosagens $\left(1,9 \times 10^{1}\right.$ p.f.u./0,05mL; $1,9 \times 10^{3}$ p.f.u/0,05mL e 3,1 x $10^{5}$ p.f.u/0,05mL); entretanto, os sinais clínicos identificados foram genéricos e nenhum animal veio a óbito (de ambos os grupos, nas três doses); através de PCR e qPCR constatou-se que apenas dois girinos e uma rã adulta foram positivos para o vírus. Para explicar resultados a autora ponderou as seguintes hipóteses: 1) A quantidade de inóculo aplicado nas rãs não foi suficiente para provocar infecção; 2) Para a manifestação dos sinais clínicos da ranavirose nesta espécie existe a necessidade de um co-fator; 3) Os animais foram infectados com FV3, mas se recuperaram ao longo do período experimental e, 4) O inóculo utilizado tem baixa virulência (ALFAIA, 2018). Portanto, a não diferenciação dos soros das tilápias testados (controle positivo e controle negativo) pode ter ocorrido em decorrência da baixa infectividade/imunogenicidade da estirpe utilizada para tilápias, potencialmente associada a algum ou mais de um dos fatores acima citados, sendo que também não foi possível detectar a presença de partículas virais pelo PCR do grupo infectado.

Não podemos descartar ainda a possibilidade de que os títulos anti-FV3símile estivessem muito baixos e o teste ELISA-IB desenvolvido não foi sensível o suficiente, em termos analíticos, para identificar a resposta entre os dois grupos controles, uma vez que, nas análises histológicas, identificou-se necrose em órgãos frequentemente acometidos pelos ranavírus. Para verificar se este seria o problema, a utilização de um anticorpo monoclonal de coelho anti-IgM de peixe, realizando-se um ELISA-I, como os autores Kim, Jung e Lee (2007), poderia confirmar os resultados encontrados com o ELISA-IB.

Apesar dos soros de rã-touro testados apresentarem PI no ELISA-IB, um indicativo de que possivelmente possam apresentar anticorpos anti-ranavírus, com o pequeno número amostral $(\mathrm{N})$ de soros utilizados (provenientes de uma única região endêmica), não podemos afirmar que esta inibição seja em decorrência de animais soro positivos. Portanto, para padronizar o ELISA-IB se faz necessário um $\mathrm{N}$ amostral maior de soros de anfíbios e, preferencialmente, de várias regiões (ranários e até mesmo 
animais silvestres). Além disso, o $\mathrm{N}$ amostral seria importante para otimizar a delimitação do ponto de corte em função da especificidade e sensibilidade que seriam determinados (GREINER; SOHR; GÖBEL, 1995). Uma questão que pode ser levantada é a realização de uma nova infecção experimental em rãs para obtenção de soros com títulos elevados para anticorpos anti-ranavírus. Neste caso, poderia ser utilizado outro isolado de FV3-símile (TAVARES, 2018), também fazendo parte do biobanco do Laboratório de Higiene Zootécnica da FZEA-USP, com um número menor de passagens em cultivo celular, e também, originário de um surto em rãs-touro.

Espera-se que futuramente os imunobiológicos desenvolvidos contribuam para o diagnóstico de ranaviroses e, como novas perspectivas, possam subsidiar outros estudos para a produção de imunógenos vacinais contra Ranavirus para a proteção de peixes, bem como de anfíbios. Dessa forma, contribuir com o aprimoramento sanitário na aquicultura brasileira. 


\section{CONCLUSÃO}

A proteína MCP recombinante (rMCP) do isolado brasileiro de Ranavirus, FV3-símile, foi produzida de forma inédita neste trabalho, através do plasmídeo construído pET28a/MCP em sistema de expressão procarioto (Escherichia coli). Apesar das dificuldades iniciais no processo de expressão e purificação, uma grande quantidade da proteína rMCP foi expressa em sua forma insolúvel, no tamanho original de 50kDa.

A partir da proteína rMCP purificada, foi possível a produção de anticorpos policlonais anti-rMCP em coelhos com sucesso, os quais apresentaram alta reatividade com a proteína rMCP, podendo ser utilizados como imunorreagentes em ensaios imunológicos para a detecção de Ranavirus, como Western Blot, ELISA, Reações de imunofluorescência indireta (RIF) e imunoperoxidase.

A padronização do teste de ELISA-IB para a detecção de ranavirose não foi completamente possível até a finalização da tese; entretanto, demonstrou-se tecnicamente promissora, postergando-se a finalização dos procedimentos para período posterior à defesa, devido à dificuldade na obtenção de soros controles positivos. 


\section{REFERÊNCIAS}

ABRANS, A. J. et al. Recent host-shifts in ranaviruses: signatures of positive selection in the viral genome. Journal of General Virology, London, v. 94, p. 2082-2093, Sep. 2013.

ASSOCIAÇÃO CULTURAL E EDUCACIONAL BRASIL - ACEB. $1^{\circ}$ Anuário brasileiro da pesca e aquicultura - 2014. Disponível em:

<http://formsus.datasus.gov.br/novoimgarq/16061/2489520_218117.pdf>. Acesso em: 27 out. 2015.

AHMAD, I. et al. Overcoming challenges for amplified expression of recombinant proteins using Escherichia coli. Protein Expression and Purification, Maryland Heights, v.144, p. 12-18, Apr. 2018.

AHNE, W. et al. Special topic review: iridoviruses associated with epizootic haematopoietic necrosis (EHN) in aquaculture. World Journal of Microbiology and Biotechnology, Dordrecht, v. 13, p. 367-373. 1997.

ALENCAR, A. L. F. Isolamento e caracterização de estirpe de Frog Virus 3-símile detectada em rãs-touro gigante (Lithobates catesbeianus) no Estado de São Paulo. 2016. 61 f. Dissertação (Mestrado) - Faculdade de Zootecnia e Engenharia de Alimentos, Universidade de São Paulo, Pirassununga, 2016.

ALFAIA, S. R. Utilização da rã-touro americana (Lithobates catesbeianus) como modelo experimental para infecção por ranavírus. 2018. 49 f. Dissertação (Mestrado) - Instituto de Pesca, São Paulo, 2018.

ALMEIDA-QUEIROZ, S. R. et al. Primeira detecção de Ranavirus associado a surtos sequenciais de mortalidade na tilapicultura brasileira. In: ENCONTRO BRASILEIRO DE PATOLOGISTAS DE ORGANISMOS AQUÁTICOS, 13., Aracaju, 2014. Anais... Aracaju, 2014. p. 60.

ALONSO, M. C. et al. Isolation of lymphocystis disease virus from sole, Solea senegalensis Kaup, and blackspot sea bream, Pagellus bogaraveo (Brünnich). Journal of Fish Diseases, Chichester, v. 28, n.4 p. 221-228, Apr. 2005.

ARIEL, E. et al. Serological survey of Australian native reptiles for exposure to ranavirus. Diseases of Aquatic Organisms, Oldendorf, v. 126, n 3, p. 173-183, Nov. 2017.

AYRES, M. et al. BioEstat 5.0: aplicações estatísticas nas áreas das ciências biológicas e médicas. Belém: Sociedade Civil Mamirauá, 2007. 364 p.

BOLLINGER, T. K. Pathology, isolation, and preliminary molecular characterization of a novel iridovirus from tiger salamanders in Saskatchewan. Journal of Wildlife Diseases, Lawrence, v. 35, n. 3, p. 413-429, July. 1999. 
BORZYM, E.; KARPINSKA, T. A.; REICHERT, M. Outbreak of ranavirus infection in sheatfish, Silurus glanis (L.), in Poland. Polish Journal of Veterinary Sciences, Poland, v. 18, n. 3, p. 607-611. 2015.

BOSCARDIN, N. R. A Produção aquícola brasileira. In: OSTRENSKY, A.; BORGHETTI, J. R.; SOTO, D. Aquicultura no Brasil: o desafio é crescer. Brasília, 2008. p. 27-72.

BRAND, M. D., et al. Water temperature affects susceptibility to ranavirus. EcoHealth, New York, v. 13, n. 2, p. 350-359, June. 2016.

BRASIL. Lei $\mathrm{n}^{\circ} 11.794$, de 8 de outubro de 2008. Regulamenta o inciso VII do $\S 1^{\circ}$ o do art. 225 da Constituição Federal, estabelecendo procedimentos para o uso científico de animais; revoga a Lei ${ }^{\circ} 6.638$, de 8 de maio de 1979; e dá outras providências. Diário Oficial da União, Poder Legislativo, Brasília, DF, 9 out. 2008. Seção 1, p. 1.

BRUNNER, J. et al. Ranavirus ecology and evolution: from epidemiology to extinction. In: GRAY, M. J.; CHINCHAR, V. G. Ranaviruses: lethal pathogens of ectothermic vertebrates. New York: Springer Open, 2015. p. 71-104.

BUENO, G. W. et al. Implementation of aquaculture parks in Federal Government waters in Brazil. Reviews in Aquaculture, Hoboken, v. 7, p. 1-12, Mar. 2015.

CAIPANG, C. M. et al. Genetic vaccines protect red seabream, Pagrus major, upon challenge with red seabream iridovirus (RSIV). Fish \& Shellfish Immunology, London, v. 21, n. 2, p. 130-138, Aug. 2006.

CANDIDO, M. Aspectos celulares e moleculares da ranavirose experimental em tilápias do Nilo (Oreochromis niloticus). 2018. 129 f. Tese (Doutorado) - Faculdade de Zootecnia e Engenharia de Alimentos, Universidade de São Paulo, Pirassununga, 2018.

CARDOSO, P. et al. First report of megalocytivirus in red piranhas (Pygocentrus nattereri) by molecular diagnosis in Brazil. International Journal of Avian \& Wildlife Biology, Edmond, v. 2, n. 3, p. 82-84, Oct. 2017.

CHEN, Z. X.; ZHENG, J. C.; JIANG, Y. L. A new iridovirus isolated from soft-shelled turtle. Virus Research, Amsterdam, v. 63, n. 1-2, p. 147-151, Sept. 1999.

CHEN, Z-H. et al. Production and characterization of a monoclonal antibody against a late gene encoded by grouper iridovirus 64L. Journal of Fish Diseases, Chichester, v. 39, n. 2, p. 129-141, Feb. 2016.

CHEM, D.; TEXADA, D. E. Low-usage codons and rare codons of Escherichia coli. Gene Therapy and Molecular Biology, Athens, v. 10, p. 1-12, 2006.

CHINCHAR, V. G. et al. Induction of apoptosis in Frog virus 3-infected cells. Virology, Waltham, v. 306, n. 2, p. 303-312, Feb. 2003.

CHINCHAR, V. G. Ranaviruses (family Iridoviridae): Emerging cold-blooded killers. Archives of Virology, Wien, v. 147, n. 3, p. 447-470, Mar. 2002. 
CHINCHAR, V. G. et al. Iridoviridae. In: FRAUQUET. C. M. et al. Virus taxonomy: 8th report of the international committee on the taxonomy of viruses. London: Elsevier, 2005. p. 163-175.

CHINCHAR, V. G. et al. Family Iridoviridae: poor viral relations no longer. Current topics in Microbiology and Immunology, New York, v. 328, p. 123-170. 2009.

CHINCHAR, V. G.; YU, K. H.; JANCOVICH, J. K. The molecular biology of frog virus 3 and other iridoviruses infecting cold-blooded vertebrates. Viruses, Basel, v. 3, n.10 p. 1959- 1985, Oct. 2011.

CHINCHAR, V. G.; WALTZEK, T. B. Ranaviruses: not just for frogs. PLOS Pathogens, San Francisco, v. 10, n. 1, p. e1003850, Jan. 2014

CHINCHAR, V. G. et al. ICTV Virus taxonomy profile: Iridoviridae. Journal of General Virology, London, v. 98, p. 890-891, Apr. 2017.

CHINCHAR, V. G.; WALTZEK, T. B.; SUBRAMANIAM, K. Ranaviruses and other members of the family Iridoviridae: Their place in the virosphere. Virology, Waltham, v. 511, p. 259-271, Nov. 2017.

CHOI, S. K. et al. Organ distribution of red sea bream iridovirus (RSIV), DNA in asymptomatic yearling and fingerling Rock bream (Oplegnathus fasciatus) and effects of water temperature on transition of RSIV into acute phase. Aquaculture, Amsterdam, v. 256, p. 23-26, Jun. 2006.

CINKOVA, K. et al. Evaluation of a polyclonal antibody for the detection and identification of ranaviruses from freshwater fish and amphibians. Diseases of Aquatic Organisms, Oldendorf, v. 89, n. 3, p.191-198, Apr. 2010.

CLAYTOR, S. C. et al. Ranavirus phylogenomics: Signatures of recombination and inversions among bullfrog ranaculture isolates. Virology, Waltham, v. 511, p. 330-343, Nov. 2017.

CORRÊA, T. C. et al. Utilização da ORF53R como marcador molecular no diagnóstico laboratorial de Ranavirus. In: REUNIÃO CIENTÍfiCA DO INSTITUTO DE PESCA, 13., 2019, São Paulo. Anais... São Paulo, 2019. p. 167-170.

CRANE, M.; HYATT, A. Viruses of fish: an overview of significant pathogens. Viruses, Switzerland, v. 3, n. 11, p. 2025-2046, Nov. 2011.

CRIBB, A. Y.; AFONSO, A. M.; MOSTÉRIO, C. M. Manual técnico de ranicultura. Brasília: EMBRAPA. 2013. 73 p.

CULLEN, B. R.; OWENS, L. Experimental challenge and clinical cases of bohle iridovirus (BIV) in native australian anurans. Diseases of Aquatic Organisms, Oldendorf, v. 49, p. 83-92, May. 2002.

CUNNINGHAM, A. A. et al. Pathological and microbiological findings from incidents of unusual mortality of the common frog (Rana temporaria). Philosophical 
Transactions of the Royal Society of London, London, v. 351, p. 1539-1557, Nov. 1996.

DE MATOS, A. P. et al. New viruses from Lacerta monticola (Serra da Estrela, Portugal): further evidence for a new group of nucleo-cytoplasmic large deoxyriboviruses. Microscopy and Microanalysis, Cambridge, v. 17, n. 1, p. 101-108, Feb. 2011.

DE VOE, R. et al. Ranavirus-ssociated morbidity and mortality in a group of captive eastern box turtles (Terrapene carolina carolina). Journal of Zoo and Wildlife Medicine, Yulee, v. 35, n. 4, p. 534-543, Dec. 2004.

DOCHERTY, D. E. et al. Diagnostic and molecular evaluation of three iridovirus associated salamander mortality events. Journal of Wildlife Diseases, Lawrence, v. 39, n. 3, p. 556- 566, July. 2003.

DOCHERTY-BONE, T. M. et al. Morbidity and mortality of the critically endangered Lake Oku clawed frog (Xenopus longipes). Endanger Species Research, Oldendorf, v. 21, p. 115-128, Aug. 2013.

DUFFUS, A. L. J. et al. Distribution and host range of ranaviruses. In: GRAY, M. J.; CHINCHAR, V. G. Ranaviruses: lethal pathogens of ectothermic vertebrates. New York: Springer Open, 2015. p. 9-57.

DUFFUS, A. L. J. et al. Phylogentic analysis of 24 ranavirus isolates from english amphibians using 2 partial loc. Journal of Emerging Diseases and Virology, Milpitas, v. 3, n. 2, June. 2017.

EATON, H. E. et al. Comparative genomic analysis of the family Iridoviridae: reannotating and defining the core set of iridovirus genes. Virology Journal, London, v4, n. 11. 2007.

ESTERHUYSEN, J. J.; PREHAUD, C.; THOMSON, G. R. A liquid-phase blocking ELISA for the detection of antibodies to rabies virus. Journal of Virological Methods, Amsterdam, v. 5, n. 1, p. 31-42, Jan. 1995.

EMMENEGGER E. J. et al. Molecular identification of erythrocytic necrosis virus (ENV) from the blood of Pacific herring (Clupea pallasii). Veterinary Microbiology, Amsterdam, v. 7, n. 174 p. 16-26, Nov. 2014.

FAKRUDDIN, M. et al. Critical factors affecting the success of cloning, expression, and mass production of enzymes by recombinant E. coli. ISRN Biotechnology, New York, v. 13, p. 590587, Aug. 2012.

FOOD AND AGRICULTURAL ORGANIZATION - FAO. The State of World Fisheries and Aquaculture 2014: opportunities and challenges. Rome: FAO, 2014. 243p.

FAO. The State of World Fisheries and Aquaculture 2016: contributing to food security and nutrition for all. Rome: FAO, 2016. 200 p. 
FAO. The State of World Fisheries and Aquaculture 2018: meeting the sustainable development goals. Rome: FAO, 2018. 227 p.

FIGUEIREDO, H. C. P.; LEAL, C. A. G. Tecnologias aplicadas em sanidade de peixes. Revista Brasileira de Zootecnia, Viçosa, v. 37, p. 8-14, jul. 2008.

FLORES, E.F. Diagnóstico laboratorial de infecções víricas: In: FLORES E. F. (Org.). Virologia Veterinária. Santa Maria: Editora UFSM, 2007. p. 295-328.

FOX, S. F. et al. First case of ranavirus-associated morbidity and mortality in natural populations of the South American frog Atelognathuspatagonicus. Diseases of Aquatic Organisms, Oldendorf, v. 72, p. 87-92, Set. 2006.

FORZÁN M. J. et al. Pathogenesis of Frog Virus 3 (Ranavirus, Iridoviridae) Infection in Wood Frogs (Rana sylvatica). Veterinary Pathology, Madison, v. 54, n. 3, p. 531548, May. 2017.

FU, X. et al. Protective immunity against iridovirus disease in mandarin fish, induced by recombinant major capsid protein of infectious spleen and kidney necrosis virus.

Fish \& Shellfish Immunology, London, v. 33, n. 4, p. 880-885, Oct. 2012.

GALLI, L. et al. Ranavirus detection by PCR in cultured tadpoles (Rana catesbeiana Shaw, 1802) from South America. Aquaculture, Amsterdam, v. 257, n. 1-4, p. 78-82, June. 2006.

GEORGE, M. R. et al. Isolation and characterization of a ranavirus from koi, Cyprinus carpio L., experiencing mass mortalities in India. Journal of Fish Diseases, Chichester, v. 38, n. 4, p. 389-403. Apr. 2015.

GOORHA, R. et al. The role of DNA methylation in virus replication: inhibition of frog virus 3 replication by 5-azacytidine. Virology, Waltham, v. 138, p. 94-102, Oct. 1984.

GRANOFF, A.; CAME, P. E.; BREEZE, D. C. Viruses and renal carcinoma of Rana pipiens. I. The isolation and properties of virus from normal and tumor tissue. Virology, Waltham, v. 29, p. 133-148, May. 1966.

GRAY, M. J.; CHINCHAR, V. G. Ranaviruses: lethal pathogens of ectothermic vertebrates. New York: Springer Open, 2015. 254 p.

GRC 2019. Global ranavirus consortium. Disponível em:

<https://www.ranavirus.org/>. Acesso em: 21 ago. 2019.

GREINER, M.; SOHR, D.; GÖBEL, P. A modified ROC analysis for the selection of cut-off values and the definition of intermediate results of serodiagnostic tests. Journal of Immunological Methods, Amsterdam, v. 185, n.1, p. 123-132, Sep. 1995.

HALL, T. A. BioEdit: a user-friendly biological se quence alignment editor and analysis program for windows 95/98/NT. Nucleic Acids Symposium Series, Oxford, v. 41, p. 95-98, 1999.

HANAHAN, D. et al. Studies on transformation of Escherichia coli with plasmids.

Journal Molecular Biology, London, v. 166, n. 4, p. 557-580, June. 1983. 
HIPOLITO, M. Manejo Sanitário no Cultivo de Rã. In: RANZANI-PAIVA, M. J. T.; TAKEMOTO, R. M.; LIZAMA, M. L. A. P. Sanidade de organismos aquáticos. São Paulo: Varela, 2004. p. 333- 353.

HOLOPAINEN, R. Ranaviruses: detection, differentiation and host immune response. 2012. 75 f. Dissertação (Mestrado). Faculty of Veterinary Medicine, University of Helsinki, Finland, 2012.

HOLOPAINEN, R. et al. Ranavirus phylogeny and differentiation based on major capsid protein, DNA polymerase and neurofilament triplet H1-like protein genes.

Diseases of Aquatic Organisms, Oldendorf, v. 85, p. 81-91, June. 2009.

HUANG, Y. et al. Complete sequence determination of a novel reptile iridovirus isolated from soft-shelled turtle and evolutionary analysis of Iridoviridae. BMC Genomics. London, v. 10, art. 224, May. 2009.

HUANG, S. M. et al. Genetic analysis of fish iridoviruses isolated in Taiwan during 2001-2009. Archives of Virology, Wien, v.156, n. 9, p. 1505-1515, Jan. 2011.

HYATT, A. D. et al. Comparative studies of piscine and amphibian iridoviruses.

Archives of Virology, Wien, v. 145, n. 2, p. 301-331, Feb. 2000.

HYATT, A. D. et al. First identification of a ranavirus from green pythons

(Chondropython viridis). Journal of Wildlife Diseases, Lawrence, v. 38, n. 2, p. 239252, Apr. 2002.

INSTITUTO BRASILEIRO DE GEOGRAFIA E ESTATÍSTICA - IBGE. Produção da Pecuária Municipal. Rio de Janeiro, v. 43, p.1-49, 2015.

INSTITUTO BRASILEIRO DE GEOGRAFIA E ESTATÍSTICA - IBGE. Produção da Pecuária Municipal. Rio de Janeiro, v. 44, p.1-51, 2016.

INTERNATIONAL COMMITTEE ON TAXONOMY OF VIRUSES - ICTV.

Iridoviridae. 2018. Disponível em: <https://talk.ictvonline.org/ictv-

reports/ictv_online_report/dsdna-viruses/w/iridoviridae>. Acesso em: 26 jul. 2019.

ISHIKAWA, M. M. et al. Procedimentos básicos para colheita de sangue em peixes. Dourados: Embrapa - Circular Técnica, 2010. p. 1-7.

JANCOVICH, J. K. et al. Evidence for emergence of an amphibian iridoviral disease because of human-enhanced spread. Molecular Ecology, Chichester, v. 14, p. 213-224, 2005 .

JANCOVICH, J. K. et al. Evidence for multiple recent host species shifts among the ranaviruses (family Iridoviridae). Journal Virology, London, v. 84, n.6, p. 2636-2647, Mar. 2010.

JANCOVICH, J. K. et al. Family Iridoviridae. In: KING A. M. Q. et al. Virus taxonomy: ninth Report of the International Committee on Taxonomy of Viruses. San Diego: Elsevier Academic Press, 2012. p. 193-210. 
JANCOVICH, J. K. et al. Ranavirus Taxonomy and Phylogeny In: GRAY, M. J.; CHINCHAR, V. G. Ranaviruses: lethal pathogens of ectothermic vertebrates. New York: Springer Open, 2015. p. 59-70.

JARAMILLO, D. et al. Serology in finfish for diagnosis, surveillance, and research: a systematic review. Journal of Aquatic Animal Health, New York, v. 29, p. 1-14, Fev. 2017.

JOHNSON, A. J. Development and use of an indirect enzyme-linked immunosorbent assay for detection of iridovirus exposure in gopher tortoises (Gopherus polyphemus) and eastern box turtles (Terrapene carolina carolina). Veterinary Microbiology, Amsterdam, v. 142, p. 160-167, May. 2010.

KANE, J. F. Effects of rare codon clusters on high-level expression of heterologous proteins in Escherichia coli. Current Opinion in Biotechnology, v. 6, p. 494-500. 1995.

KIM, T. J.; JUNG, T. S.; LEE, J. I. Expression and serological application of a capsid protein of an iridovirus isolated from rock bream, Oplegnathus fasciatus (Temminck \& Schlegel). Journal of Fish Diseases, Chichester, v. 30, n. 11, p. 691-699, Nov. 2007.

KIM, T. J.; JANG E. J.; LEE, J. I. Vaccination of rock bream, Oplegnathus fasciatus (Temminck \& Schlegel), using a recombinant major capsid protein of fish iridovirus. Journal of Fish Diseases, Chichester, v. 31, n. 11, p. 547-551, July. 2008.

KIM, Y. R. et al. Development of an immunochromatography assay kit for rapid detection of ranavirus. Journal of Virological Methods, Amsterdam, v. 223, p. 33-39, Oct. 2015.

KURITA, J.; NAKAJIMA, K. Megalocytiviruses. Viruses, Basel, v. 4, n. 4 p. 521-538, Apr. 2012.

LESBARRÈRES, D. et al. Ranavirus: past, present and future. Biology Letters, London, v. 8, n. 4, p. 481-483, Aug. 2012.

LIBEAU, G. et al. Development of a competitive ELISA for detecting antibodies to the peste des petits ruminants virus using a recombinant nucleoprotein. Research in Veterinary Science, London, v. 58, n. 1, p. 50-55, Jan. 1995.

LIN, H-Y. et al. Development and application of a monoclonal antibody against groupe iridovirus (GIV) major capsid protein. Journal of Virological Methods, Amsterdam, v. 205, p 31-37, Sept. 2014.

LIN, H-Y. et al. Identification and characterization of a late gene encoded by grouper iridovirus 2L (GIV-2L). Journal of Fish Diseases, Chichester, v. 38, p. 881-890, Oct. 2015

LIU, H. I. et al. Cloning of the Major Capsid Protein (MCP) of Grouper Iridovirus of Taiwan (TGIV) and preliminary evaluation of a recombinant MCP vaccine against 
TGIV. International Journal of Molecular Sciences, Basel, v. 16, p. 28647-28656, Dec. 2015.

LANGDON, J. S. et al. First virus isolation from Australian fish: An iridovirus-like pathogen from redfin perch, perca fluviatilis 1. Journal of Fish Diseases, Chichester, v. 9, n. 3, p. 263-268, 1986.

MACHIMBIRIKE, V. I.et al. Viral infections in tilapines: More than just tilapia lake virus. Aquaculture, Amsterdam, v. 503, p. 508-518, Jan. 2019.

MAGANHA, S. R. L. et al. Molecular detection and phylogenetic analysis of megalocytivirus in Brazilian ornamental fish. Archives of Virology, Wien, v. 163, p. 2225-2231, Aug. 2018.

MAGANHA, S. R. L. et al. Detection and molecular characterization of Lymphocystivirus in Brazilian ornamental fish. Brazilian Journal of Microbiology, 2019. no prelo.

MAHARDIKA, K.; MASTUTI, I. The effects of crude recombinant viral protein vaccines against grouper sleepy disease iridovirus (GSDIV) on humpback grouper (Cromileptes altivelis). Indonesian Aquaculture Journal, Jakarta, v.10, n. 2, p. 163 172. Nov. 2015.

MAHARDIKA, K. et al. Addition of adjuvants in recombinant subunit vaccines for the prevention of grouper sleepy disease iridovirus (GSDIV) infection in humpback grouper, Cromileptes altivelis. Indonesian Aquaculture Journal, Jakarta, v.11, n. 2, p. 87-95. Nov. 2016.

MAJJI, S. et al Transcriptome analysis of Frog virus 3, the type species of the genus Ranavirus, family Iridoviridae. Virology, Waltham, v. 391, n. 2, p. 293-303, Sep. 2009

MAO, J.; HEDRICK, R. P.; CHINCHAR, V. G. Molecular characterization, sequence analysis, and taxonomic position of newly isolated fish iridoviruses. Virology, Waltham, v. 229, n. 1, p. 212-220, Mar. 1997.

MARTINS, M. L. Manejo sanitário na piscicultura. In: RANZANI-PAIVA, M. J. T.; TAKEMOTO, R. M.; LIZAMA, M. L. A. P. Sanidade de organismos aquáticos. São Paulo: Varela, 2004. p. 323- 332.

MARSCHANG, R. E. et al. Isolation and characterization of an iridovirus from Hermann's tortoises (testudo hermanni). Archives of Virology, Wien, v. 144, n. 10, p. 1909-1922, 1999.

MARSH, I. B. et al. Rapid differentiation of Australian, European and American ranaviruses based on variation in major capsid protein gene sequence. Molecular and Cellular Probes, London, v. 16 n. 2, p. 137-151, Apr. 2002.

MAZZONI, R. et al. Mass mortality associated with a Frog virus 3-like ranavirus infection in farmed tadpoles Rana catesbeiana from Brazil. Diseases of Aquatic Organisms, Oldendorf, v. 86 n. 3, p. 181-191, Nov. 2009. 
MILLER, D. et al. Comparative Pathology of Ranaviruses and Diagnostic Techniques. In: GRAY, M. J.; CHINCHAR, V. G. Ranaviruses: lethal pathogens of ectothermic vertebrates. New York: Springer Open, 2015. p. 171-208.

MESQUITA, A. Q. Síndrome vestibular em Lithobates catesbeianus associada à Ranavirus. 2014. 80 f. Tese (Doutorado) - Universidade Federal de Goiás, Goiânia, 2014.

MIHALJEVIC, J. R.; HOVERMAN, J. T.; JOHNSON, P. T. J. Co-exposure to multiple ranavirus types enhances viral infectivity and replication in a larval amphibian system. Diseases of Aquatic Organisms, Oldendorf, v. 132, n. 1, p. 23-35, Dec. 2018.

MIN, Z. et al. A loop-mediated isothermal amplification method for the detection of members of the genus Ranavirus. Archives of Virology, Wien, v. 158, p. 2121-2126, Oct. 2013.

NEVES, N. P. et al. Use of polyclonal antibodies, electron microscopy and histopathology to detect Iridovirus-like particles in bullfrogs. Boletim do Instituto de Pesca, São Paulo, v. 42, p. 523-53, nov. 2016.

OIE World Organization for Animal Health. Infection with Ranavirus. In: Manual of diagnostic tests for aquatic animals. Paris: OIE, 2012. p. 71-91.

OIE World Organization for Animal Health. Manual of diagnostic tests for aquatic animals. Paris: OIE, 2015. Disponível em: <http://www.oie.int/international-standardsetting/aquatic-manual/> . Acesso em: 18 out. 2015.

OIE. OIE-Listed diseases, infections and infestations in force in 2019. 2019.

Disponível em: <https://www.oie.int/animal-health-in-the-world/oie-listed-diseases2019/>. Acesso em: 21 ago. 2019.

OLIVEIRA, C. R. et al. Detection and molecular characterization of Frog virus 3 in bullfrogs from frog farms in Brazil. Aquaculture, Amsterdam, v. 516, art. 734575, Feb. 2020.

OVERTON, T. W. Recombinant protein production in bacterial hosts. Drug Discovery Today, London, v. 19 n. 5, p. 590-601, May. 2014.

PEIXE BR - Associação Brasileira da Piscicultura. Anuário Peixe BR 2019.

Disponível em: <https://www.peixebr.com.br/anuario-peixe-br-da-piscicultura-2019/>. Acesso em: 26 ago. 2019.

PENG, C. et al. Susceptibility of farmed juvenile giant grouper Epinephelus lanceolatus to a newly isolated grouper iridovirus (genus Ranavirus). Veterinary Microbiology, Amsterdam, v. 177, n. 3-4, p. 270-279, June. 2015.

PEREIRA. S. A. et al. Sanidade e perspectivas para ranicultura. In: TAVARES DIAS, M.; MARIANO, W. S. (org.). Aquicultura no Brasil: novas perspectivas. São Carlos: Editora Pedro \& João, 2015. p. 263-282 
PLUMB, J. A. et al. An iridovirus isolated from wild largemouth bass. Journal of Aquatic Animal Health, New York, v. 8, n. 4, p. 265-270, 1996.

PRICE, S. J. et al. From fish to frogs and beyond: Impact and host range of emergent ranaviroses. Virology, Waltham, v. 511, p. 272-279. Nov. 2017.

PURCELL, M. K. et al. Identification of the major capsid protein of erythrocytic necrosis virus (ENV) and development of quantitative real-time PCR assays for quantification of ENV DNA. Journal of Veterinary Diagnostic Investigation, Thousand Oaks, v. 28, n. 4, p. 382-391, July. 2016.

RAHNAMA, R. et al. Designing an in house ELISA to detect antibody against viral haemorrhagic septicaemia virus using recombinant $\mathrm{N}$ protein in Iranian farmed rainbow trout (Oncorhynchus mykiss). Aquaculture Research, Chichester, v. 50, p. 474-482, Dec. 2019.

ROBERT, J.; CHINCHAR, G. V. "Ranaviruses: an emerging threat to ectothermic vertebrates" report of the First International Symposium on Ranaviruses, Minneapolis MN July 8, 2011. Developmental and Comparative Immunology, v. 36, n. 2, p. 256261, Feb. 2012.

RUGGERI, J. et al. Discovery of wild amphibians infected with ranavirus in Brazil. Journal of Wildlife Diseases, Lawrence, v. 55, n. 4, p. 897-902, Oct. 2019.

SIQUEIRA, T. V. Aquicultura: a nova Fronteira para aumentar a produção mundial de alimentos de forma sustentável. IPEA - Boletim regional, urbano e ambiental, Brasília, p. 53-60, jul./dez. 2017.

SHEVCHENKO, A. et al. In-gel digestion for mass spectrometric characterization of proteins and proteomes. Nature Protocols, London, v. 1, n. 6, p. 2856-2860, 2006.

TAVARES, L. S. Isolamento, identificação fenogenotípica e avaliação da indução de apoptose por estirpe brasileira de Frog vírus 3-like, oriunda de Lithobates catesbeianus. 2018. 100 f. Dissertação (Mestrado) - Faculdade de Zootecnia e Engenharia de Alimentos, Universidade de São Paulo, Pirassununga, 2018.

TIZARD, I. R. Evolução do sistema immune. Imunologia veterinária: uma introdução. 8. ed. Rio de Janeiro: Elsevier, 2009. p. 504- 511.

WALKER, P. J.; WINTON, J. R. Emerging viral diseases of fish and shrimp. Veterinary Research, London, v. 41, p. 1-24, Nov. 2010.

WANG, S. et al. Entry of a novel marine DNA virus, Singapore grouper iridovirus, into host cells occurs via clathrin-mediated endocytosis and macropinocytosis in a $\mathrm{pH}$ dependent manner. Journal Virology, London, v. 88, n. 22, p. 13047-13063, Nov. 2014. WATERHOUSE, A. M. et al. Jalview Version 2 - a multiple sequence alignment editor and analysis workbench. Bioinformatics, Oxford, v. 25, p. 1189-1191, May. 2009. 
WHITTINGTON, R. J.; BECKER, J. A.; DENNIS, M. M. Iridovirus infections in finfish - critical review with emphasis on ranaviruses. Journal of Fish Diseases, Chichester, v. 33, n. 2, p. 95-122, Feb. 2010.

WILLIAMS, T.; BARBOSA-SOLOMIEU, V.; CHINCHAR, V. G. A decade of advances in iridovirus research. Advances in Virus Research, Maryland Heights, v. 65, p. 173248,2005

WINZELER, M. E. et al. First case of ranavirus and associated morbidity and mortality in an eastern mud turtle Kinosternon subrubrum in South Carolina. Diseases of Aquatic Organisms, Oldendorf, v. 114, p. 77-81, May. 2015.

WIRTH, W. W. et al., Ranaviruses and reptiles. PeerJ - Life \& Environmental, London, v. 6, p. e6083. Dec. 2018

WOLF, K. et al. Tadpole edema virus: a viscerotropic pathogen for anuran amphibians. The Journal of Infectious Diseases, Cary, v. 118, n. 3, p. 253-262, June. 1968.

ZHANG, Q. Y. et al Characterization of an iridovirus from the cultured pig frog (Rana grylio) with lethal syndrome. Diseases of Aquatic Organisms, Oldendorf, v. 48, p. 2736, Dec. 2001.

ZHANG, Q.; GUI, J. F. Virus genomes and virus-host interactions in aquaculture animals. Science China. Life Sciences, Beijing, v. 58, n. 2, p. 156-69, Feb. 2015.

ZHOU, Z. Y. et al. Characterization of a ranavirus isolated from the Chinese giant salamander (Andrias davidianus, Blanchard, 1871) in China. Aquaculture, Amsterdam, v. 25, p. 66-73, Mar. 2013.

ZHOU, Y. et al. Protective immunity of a Pichia pastoris expressed recombinant iridovirus major capsid protein in the Chinese giant salamander, Andrias davidianus. Vaccine, London, v. 33, n. 42, p. 5662-5669. Oct. 2015.

ZIEGLER, M. F. Anfíbios infectados por ranavírus são detectados na Mata Atlântica: patógeno está relacionado ao declínio ou extinção de populações de anfíbios em outras partes do mundo. Jornal da UNICAMP, Campinas, 28 maio 2019. Disponível em: <https://www.unicamp.br/unicamp/ju/noticias/2019/05/28/anfibios-infectados-porranavirus-sao-detectados-na-mata-atlantica>. Acesso em: 28 ago. 2019.

ZUPANOVIC, Z. et al. Isolation and characterization of iridoviruses from the giant toad Bufo marinus in Venezuela. Diseases of Aquatic Organisms, Oldendorf, v. 33, p. 1-9, May. 1998. 


\begin{abstract}
ANEXO
Meio LB (Luria-Bertani)

$10 \mathrm{~g}$ Triptona

$10 \mathrm{~g} \mathrm{NaCl}$

$5 \mathrm{~g}$ Extrato de levedura

$\mathrm{H}_{2} \mathrm{O}$ destilada q.s.p $1000 \mathrm{~mL}$

Ajuste o pH a 7,0 com $\mathrm{NaOH}$. Autoclave e armazene em geladeira. Adicione o antibiótico na concentração desejada antes do uso.
\end{abstract}

\title{
LB ágar
}

Adicionar 1,5\% de ágar bacteriológico em Meio LB. Autoclave e deixe esfriar a $50^{\circ} \mathrm{C}$ antes de adicionar o antibiótico na concentração desejada. Preparar placas de Petri com $20 \mathrm{~mL}$ a $25 \mathrm{~mL}$, deixe o ágar solidificar e armazene a $4^{\circ} \mathrm{C}$ por até 30 dias.

\section{Tampão de lise}

50 mM Fosfato de potássio, pH 7.8

$400 \mathrm{mM} \mathrm{NaCl}$

$100 \mathrm{mM} \mathrm{KCl}$

$10 \%$ Glicerol

$0.5 \%$ Triton $\mathrm{X}-100$

$10 \mathrm{mM}$ Imidazol

Prepare soluções estoque de $1 \mathrm{M}$ de $\mathrm{KH}_{2} \mathrm{PO}_{4}$ e $\mathrm{K}_{2} \mathrm{HPO}_{4}$. Para $100 \mathrm{~mL}$, dissolva os seguintes reagentes em $90 \mathrm{~mL}$ de $\mathrm{H}_{2} \mathrm{O}$ Milli-Q:

$0,3 \mathrm{~mL} \mathrm{KH}_{2} \mathrm{PO}_{4}$

$4,7 \mathrm{~mL} \mathrm{~K}_{2} \mathrm{HPO}_{4}$

$2,3 \mathrm{~g} \mathrm{NaCl}$

$0,75 \mathrm{~g} \mathrm{Kcl}$

$10 \mathrm{~mL}$ Glicerol

$0,5 \mathrm{~mL}$ Triton $\mathrm{X}-100$

$68 \mathrm{mg}$ Imidazole

Misture bem e ajuste o $\mathrm{pH}$ a 7,8 com $\mathrm{HCl}$. Traga o volume para $100 \mathrm{~mL}$ e armazene a $4^{\circ} \mathrm{C}$.

\section{Gel de Poliacrilamida 10\%}

Gel de corrida:

2,5mL Acrilamida $40 \%$

2,5mL 1.5M Tris-Hcl pH 8.8 
$100 \mu \mathrm{L} 10 \%$ SDS

$3,6 \mathrm{~mL} \mathrm{H}_{2} \mathrm{O}$ destilada

$100 \mu \mathrm{L}$ Persulfato de amônio (APS) 10\%

$10 \mu \mathrm{L}$ Temed

Gel de empilhamento:

$625 \mu \mathrm{L}$ Acrilamida 40\%

$1,575 \mu \mathrm{L}$ 0,5M Tris-Hcl pH 6.8

$62,5 \mu \mathrm{L} 10 \%$ SDS

$3,975 \mu$ L Persulfato de amônio (APS) $10 \%$

$62,5 \mu \mathrm{L}$ Temed

$13 \mu \mathrm{L} \mathrm{H}_{2} \mathrm{O}$ destilada

\section{Solução de fixação e coloração}

10\% Ácido acético

$40 \% \mathrm{H}_{2} \mathrm{O}$ destilada

$50 \%$ Metanol

Preparar um volume de $100 \mathrm{~mL}$, utilize $30 \mathrm{~mL}$ para fixação. No restante do volume adicione 0,25\% de Coomassie Brilliant blue R250 Dye (p/V).

\section{Solução de descoloração}

$67,5 \% \mathrm{H}_{2} \mathrm{O}$ destilada

$7,5 \%$ Ácido acético

$25 \%$ Metanol

Preparar aproximadamente $500 \mathrm{~mL}$.

\section{Tampão 10X TBS-T (solução estoque)}

$43,83 \mathrm{~g} \mathrm{NaCl}$

30,39g Tris-base

$5 \mathrm{~mL}$ Tween 20

$\mathrm{HCl}$ puro para chegar ao $\mathrm{pH} 7,5$

$\mathrm{H}_{2} \mathrm{O}$ Milli-Qq.s.p 500mL

Para solução de uso diluir a 1X TBS-T.

\section{Tampão TBS-T + BSA}

Adicione $5 \%$ de BSA a $1 \mathrm{X}$ TBS-T $(\mathrm{p} / \mathrm{V})$ e armazene a $4^{\circ} \mathrm{C}$. Preparar pouca quantidade e próximo ao uso. 


\section{Soluções espectrometria de massas}

Maiores informações no site do Laboratório Max Feffer de Genética de Plantas: http://genfis40.esalq.usp.br/genfis/index.php?option=com_phocadownload\&view=categ ory\&id=8:protocolos\&Itemid=93

Solução de descoloração: 50\% (v/v) de acetonitrila (ACN) (e $25 \mathrm{mM}$ de bicarbonato de amônio $(\mathrm{AmBic})\left(\mathrm{NH}_{4} \mathrm{HCO}_{3}\right)=[0.1 \mathrm{~g} / 50 \mathrm{~mL}$ água Milli-Q]. Essa solução pode ser feita a partir da solução estoque de 50 mMAmBic.

Solução de redução: $20 \mathrm{mMditiotreitol}(\mathrm{DTT})=[30 \mathrm{mg} / 10 \mathrm{~mL}$ de solução 50 mMAmBic $=[0.2 \mathrm{~g} / 50 \mathrm{~mL}$ água Milli-Q].

Solução de alquilação: $55 \mathrm{mM}$ de iodoacetamida (IAA) $=[102 \mathrm{mg} / 10 \mathrm{~mL}$ de solução 50 mMAmBic. Obs: o IAA é sensível à luz, o frasco deve ser envolto com papel alumínio.

Solução de tripsina (PromegaTrypsin): estoque de $10 \mathrm{ng} / \mu \mathrm{L}$.

Solução bloqueadora: 5\% (v:v) ácido fórmico 96\% em 50\% (v:v) ACN. Para 2 mL, aliquotar $1 \mathrm{~mL}$ de $\mathrm{ACN} 100 \%$ em um frasco de vidro, pipetar $104.16 \mu \mathrm{L}$ de ácido fórmico (96\%) e completar o volume para $2 \mathrm{~mL}$, com água Milli-Q $(895.84 \mu \mathrm{L})$.

Solução de eluição I: $1 \%$ (v:v) ácido fórmico (96\%) em 60\% (v:v) metanol. Para 2 mL, aliquotar $1.2 \mathrm{~mL}$ de metanol $100 \%$ em um frasco de vidro, pipetar $20.83 \mu \mathrm{L}$ de ácido fórmico (96\%) e completar o volume para $2 \mathrm{~mL}$, com água Milli-Q $(779.17 \mu \mathrm{L})$.

Solução de eluição II: $1 \%$ (v:v) ácido fórmico em 50\% (v:v) ACN. Para 2 mL, aliquotar $1 \mathrm{~mL}$ de ACN $100 \%$ em um frasco de vidro, pipetar $20.83 \mu \mathrm{L}$ de ácido fórmico (96\%) e completar o volume para $2 \mathrm{~mL}$, com água Milli-Q $(979.17 \mu \mathrm{L})$.

Soluções: ZipTips ${ }^{\circledR}{ }_{\mathrm{C} 18}$

Solução I: 0.1\% (v:v) Ácido Trifluoracético (TFA) em 100\% ACN.

Solução II: $0.1 \%$ (v:v) TFA em 50\% (v:v) solução de ACN em água Milli-Q.

Solução III: $0.1 \%$ (v:v) TFA em água Milli-Q.

Solução IV: 0.1\% (v:v) TFA em 5\% (v:v) solução de metanol em água Milli-Q.

LC-MS ${ }^{\mathrm{E}}$

Eluente A: 100\% água Milli-Q contendo 0,1\% (v:v) de ácido fórmico 
Eluente B: $100 \%$ acetonitrila contendo 0,1\% (v:v) ácido fórmico

Tampão de diálise, após purificação kit ProBond ${ }^{\mathrm{TM}}$ Purification System

Preparar 1L de Tris $10 \mathrm{mM}$ e Triton-X 100 a 0,1\%, ajustar para o $\mathrm{pH} 8,0$.

Tampões utilizados na purificação de proteína pelo kit Talon ${ }^{\circledR}$ Superflow $^{\mathrm{TM}}$ Metal Affinity Resin

- Tampão de Equilíbrio e Lavagem pH 7,4

50mM Fosfato de sódio

$300 \mathrm{mM} \mathrm{NaCl}$

$5 \mathrm{mM}$ Imidazol

$6 \mathrm{M}$ Ureia

- Tampão de Eluição pH 7,4

50mM Fosfato de sódio

$300 \mathrm{mM} \mathrm{NaCl}$

200mM Imidazol

6M Ureia

- Tampão de Dialise (refolding) pH 7.0

Tampão 1

5M Ureia

50mM Fosfato de sódio

$10 \mathrm{mM} \mathrm{MgCl} 2$

2mM $\beta$-mercaptoetanol

$0,01 \%$ Tween 20

$5 \%$ Glicerol 


\section{Tampão 2}

50mM Fosfato de sódio

$10 \mathrm{mM} \mathrm{MgCl} 2$

$0,01 \%$ Tween 20

$5 \%$ Glicerol

Através da regra $C_{1} \times V_{1}=C_{2} \times V_{2}$ os tampões 1 e 2 são trocados para efetuar a diminuição gradativa da molaridade de ureia na amostra no processo de diálise.

\section{Soluções utilizadas no ELISA-IB}

- Carbonato-Bicarbonato 0,05M pH 9,6

$0,264 \mathrm{~g} \mathrm{CNa}_{2} \mathrm{O}_{3}$

$0,210 \mathrm{~g} \mathrm{NaHCO}_{3}$

água destilada q.s.p $50 \mathrm{~mL}$

- PBS-T

1X PBS (Bio-Rad Laboratories)

$0,05 \%$ Tween 20

Ajustar, se necessário, para o pH 7,4

- PBS-T + BSA 5\%

1X PBS-T acrescido 5\% de BSA (p/V) 